\section{PENEGAKAN HUKUM \\ TERHADAP PELAKU TINDAK PIDANA KORUPSI}

Korupsi merupakan suatu tindakan yang sangat tidak terpuji dan budaya korupsi sudah mengakar Indonesia hingga saat ini belum mampu lepas dari wabah korupsi. Walaupun telah banyak peraturan dan undang-undang yang alkeluarkan untuk mencegah semakin melajunya tingkat kualitas dan kuantitas kejahatan korupsi ini. Tingkat pertumbuhan dan perkembangan tindak pidana korupsi di Indonesia sudah menjadi suatu fenomena yang sejak dulu sulit dibantah dengan argumentasi apapun. Semenjak disahkannya Undang-undang Nomor 31 Tahun 1999 Tentang Pemberantasan Tindak Pidana Korupsi pada tanggal 16 Agustus 1999 dan kemudian Undang-undang Nomor 20 tahun 2001 Tentang Perubahan atas Undang-undang Nomor 31 tahun 1999 Tentang Pemberantasan Tindak Pidana Korupsi pada tanggal 21 November 2001 amun hingga saat ini belum mampu untuk mengungkapkan pelaku dari tindakan korupsi tersebut. sohingga dalam untuk mengungkapkan pelaku dari tindakan korupsi tor pern (KPK) benat penegak hukum Kepolisian, Kejaksaan dan Komisi Pemberantasan Korupsi (KPK) benar-benar harus didorong untuk penanganan dan penindakannya. Peran serta Masyarakat sangat diperlukan dalam hal ini. korupsi yang umumnya merupakan perilaku sebagian kecll anggota masyarakat yang berlinaung dibalik kewenangan atau kekuasaan tertentu yang dapat dikaitkan dengan kekuasaan jabatan, wajib diberantas secara sistem dan terstruktur. Penegakan hukum harus dijalankan oleh para penegak hukum dan bantuan masyarakat untuk bersinergi. Pada akhirnya Tindak Pidana Korupsi harus segera di berantas dengan memberi kewenangan penuh kepada para penegak hukum kepolisian, kejaksaan dan kpk, dan yang terpenting para penegak hukum menjalankan tugasnya harus sesuai dengan peraturan perundang-undangan yang berlaku. Tujuan dibuat buku ini yang berjudul "Penegakan Hukum Terhadap Pelaku Tindak Pidana Korupsi " untuk menambah referensi bagi setiap anak bangsa yang turut membantu negara dalam membarantas korupsi dan membangun kesadaran moral anak bahwa harus memiliki integritas yang tinggi sehingga tidak terjerumus dalam tindakan korupsi karena ulah dari korupsi membuat masyarakat yang tegas bagi setiap pejabat negara yang tebukt secara hukum melakukan tindak yang tegas bag se pidana korupsi.

W.P.J. Pompe menegaskan bahwa titik berat hukum pidana dalam perkembangannya saat ini adalah kepentingan umum atau kepentingan masyarakat. Oleh karenanya, kunci pokok yang paling utama dalam penegakan hukum tindak pidana korupsi adalah menciptakan suatu komitmen dari penegak hukum untuk bekerja secara profesional dan memberikan penelusuran alat-alat bukti yang cerdas. Dengan demikian. pengungakapan alat-alat bukti sangat mudah untuk ditelusuri, karena peraturan perundang-undangan vang terkait sudah cukup memadai Ancaman pidana terberat dengan pidana matibagiparakoruptor sangat jelas dibunyikan dalam pasalyang terdapat dalam Undan maka pak dalam Undang-undang tinak pian tersebut belum pernah dilaksanakan. Sehingga pada akhirnya tuju
kepastian dan kemanfaatan hukum belum tercapai dengan baik.

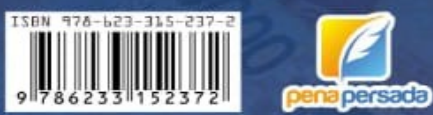

Dolfries Jakop Neununy,S.Pd.,MH

Mirja Ohoibor, SH., MH

PENEGAKAN

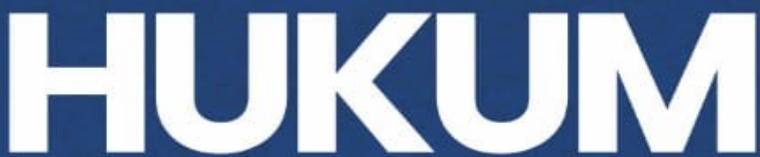

TERHADAP PELAKU

TINDAK PIDANA

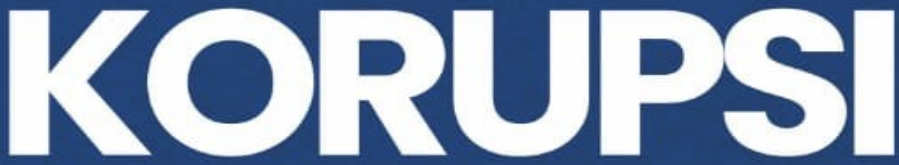

윰

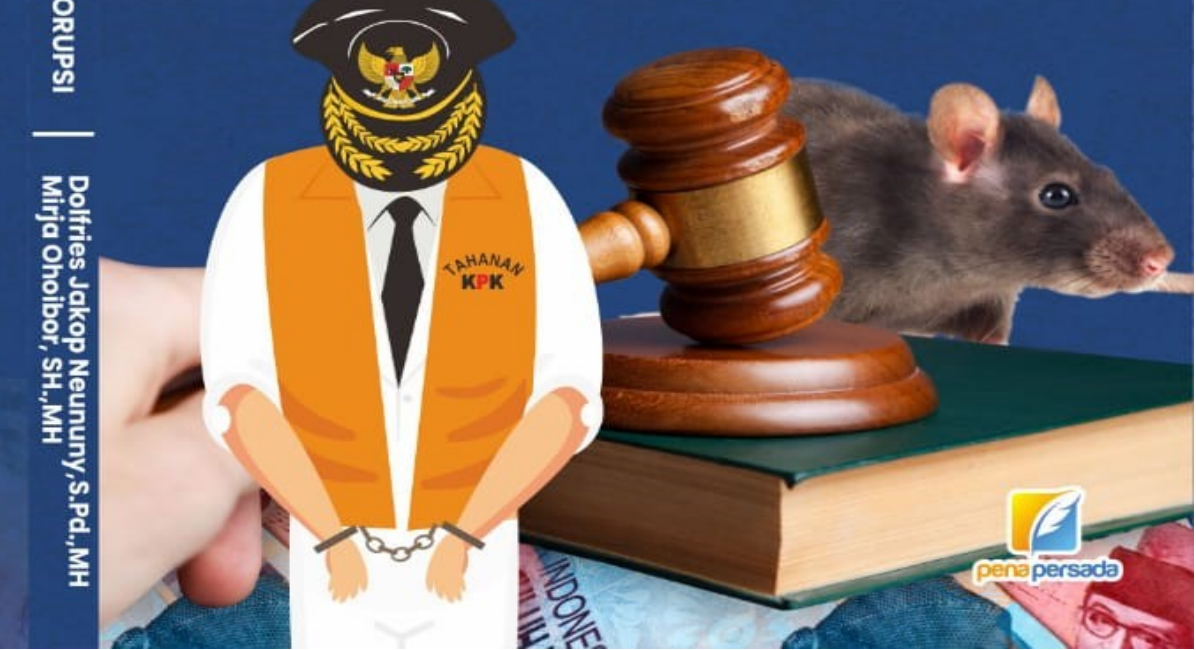





\title{
PENEGAKAN HUKUM TERHADAP PELAKU TINDAK PIDANA KORUPSI
}

\author{
Dolfries Jakop Neununy,S.Pd.,MH Mirja \\ Ohoibor, SH.,MH
}

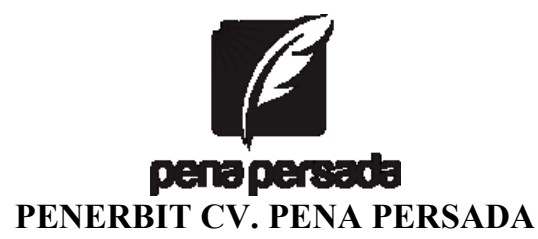




\section{PENEGAKAN HUKUM TERHADAP PELAKU TINDAK PIDANA KORUPSI}

Penulis:

Dolfries Jakop

Neununy,S.Pd.,MH Mirja

Ohoibor, SH.,MH

ISBN : 978-623-315-237-2

Editor:

Umar Abduloh

Design Cover :

Retnani Nur Briliant

Layout :

Hasnah Aulia

\section{Penerbit CV. Pena Persada Redaksi}

J1. Gerilya No. 292 Purwokerto Selatan, Kab. Banyumas Jawa Tengah

Email : penerbit.penapersada@gmail.com

Website : penapersada.com Phone : (0281) 7771388

\section{Anggota IKAPI}

All right reserved

Cetakan pertama : 2021

Hak Cipta dilindungi oleh undang-undang. Dilarang memperbanyak karya tulis ini dalam bentuk apapun tanpa izin penerbit 


\section{KATA PENGANTAR}

Puji syukur saya panjatkan kepada Tuhan Yang Maha Esa, karena atas berkat dan rahmat-Nya, saya dapat menyelesaikan buku ini. Penulisan buku merupakan buah karya dari pemikiran penulis yang diberi judul "Penegakan Hukum Terhadap Pelaku Tindak Pidana Korupsi”. Saya menyadari bahwa tanpa bantuan dan bimbingan dari berbagai pihak sangatlah sulit bagi saya untuk menyelesaikan karya ini. Oleh karena itu, saya mengucapkan banyak terima kasih pada semua pihak yang telah membantu penyusunan buku ini. Sehingga buku ini bisa hadir di hadapan pembaca.

Penulis akan membahas lebih rinci mengenai faktor-faktor apasaja yang menyebabkan terjadinya tindak pidana korupsi di Kabupaten Buru dan bagaimana bentuk penegakan hukum terhadap pelaku tindak pidana korupsi di Kabupaten Buru. Tujuan yang diharapkan dari penulisan buku ini adalah untuk mengetahui dan mengkonstruksikan secara baik terhadap faktorfaktor yang dominan mempengaruhi subjek hukum sehingga menyebabkan terjadinya tindak pidana korupsi di Kabupaten Buru dan untuk mengetahui dengan membahas secara juridis serta dapat menjelaskan pelaksanaan penegakan hukum oleh lembaga penegak hukum terhadap pelaku tindak pidana korupsi di Kabupaten Buru.

Penulis menyadari bahwa buku ini masih jauh dari kesempurnaan. Oleh karena itu kritik dan saran yang membangun sangat dibutuhkan guna penyempurnaan buku ini. Akhir kata saya berharap Tuhan Yang Maha Esa berkenan membalas segala kebaikan semua pihak yang telah membantu. Semoga buku ini akan membawa manfaat bagi pengembangan ilmu pengetahuan. 


\section{DAFTAR ISI}

KATA PENGANTAR..........................................................................iii

DAFTAR ISI .............................................................................iv

BAB I PENDAHULUAN

A. Wabah Korupsi Di Indonesia ...................................... 1

B. Dasar Hukum Pemberatasan Korupsi ............................. 3

C. Penegakan Hukum Tindak Pidana Korupsi.................... 6

BAB II SISTEM NEGARA HUKUM
A. Teori Negara Hukum. 17
B. Teori Sistem Hukum 22
C. Teori Penegakan Hukum .................................................. 24
D. Teori Penanggulangan Kejahatan .................................... 31
E. Teori Kebijakan Hukum Pidana............................................39

\section{BAB III KONSEPSI TINDAK PIDANA KORUPSI}

A. Konsepsi Korupsi Secara Umum ................................... 45

B. Konsepsi Tindak Pidana Korupsi Secara Etimologis ....... 47

C. Konsepsi Tindak Pidana Korupsi dalam Pandangan Ahli 48

D. Konsepsi Tindak Pidana Korupsi dalam Undang-Undang di Indonesia ..........................................................52

E. Kedudukan Korupsi Sebagai Tindak Pidana Khusus.......62

BAB IV LEMBAGA PENEGAKAN HUKUM DALAM SISTEM PERADILAN PIDANA DI INDONESIA

A. Sistem Peradilan Pidana Di Indonesia ............................. 68

B. Lembaga Penegak Hukum dalam Sistem Peradilan Pidana di Indonesia....................................................... 71

C. Mekanisme / Tata Acara Penegakan Hukum Dalam Sistem Peradilan Pidana Di Indonesia ........................... 75

\section{BAB V SISTEM PERADILAN TINDAK PIDANA KORUPSI DI} INDONESIA

A. Peradilan Tindak Pidana Korupsi 79

B. Hukum Acara atau Tahapan Sistem Peradilan Tindak Pidana Korupsi.... 82

\section{BAB VI GAMBARAN UMUM PENYELENGGARAAN} PEMERINTAHAN

A. Sejarah Singkat Kabupaten Buru..................................... 104

B. Kondisi Geografi Wilayah Administratif Pemerintahan ... 106 C. Satuan Kerja Perangkat Daerah (SKPD) Pada Lingkup 


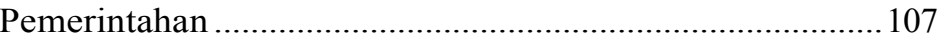

D. Kondisional Aparatur Sipil Negara Pada Pemda ................109

E. Jumlah Tenaga Honorer Kabupaten ................................ 114

BAB VII INDIKATOR TERJADINYA TINDAK PIDANA KORUPSI DAN PENEGAKAN HUKUM

A. Indikator Terjadinya Tindak Pidana Korupsi

1. Tindak Pidana Korupasi Di Kabupaten Buru

2. Faktor-Faktor Penyebab Terjadinya Tindak Pidana Korupsi

130

3. Indikator Terjadinya Tindak Pidana Korupsi 136

B. Proses Penegakan Hukum Bagi Pelaku Tindak Pidana Korupsi.

1. Penegakan Hukum Tindak Pidana Korupsi Di Tingkat Penyelidikan dan Penyidikan 139

2. Penegakan Hukum Tindak Pidana Korupsi Di Tingkat Penuntutan 136

3. Penegakan Hukum Tindak Pidana Korupsi Di Tingkat Pengadilan

137

4. Penegakan Hukum Oleh Lembaga Pelaksana Putusan Pengadilan/Lembaga eksekutor/Pemasyarakatan 140

C. Analisis Penegakan Hukum Tindak Pidana Korupsi 140

BAB VIII PENUTUP 143

DAFTAR PUSTAKA 145 


\section{PENEGAKAN HUKUM TERHADAP PELAKU TINDAK PIDANA KORUPSI}




\section{BAB I \\ PENDAHULUAN}

\section{A. Wabah Korupsi Di Indonesia}

Dalam penyelenggaraan tata kelola pemerintahan korupsi merupakan suatu jenis kejahatan yang dari dulu hingga sekarang tetap menarik untuk dibicarakan. Hal ini karena perbuatan korupsi telah dikenal sejak zaman dulu dan sekarang semakin marak terjadi seiring dengan perkembangan penyelenggaraan pemerintahan. Korupsi juga dikenal telah mewabah di banyak Negara dan menyeret nama tokoh-tokoh penting dan berpengaruh pada kelembagaankelembagaan Negara.

Indonesia hingga saat ini belum mampu lepas dari wabah korupsi. Walaupun telah banyak peraturan dan undang- undang yang dikeluarkan untuk mencegah semakin melajunya tingkat kualitas dan kuantitas kejahatan korupsi ini. Tingkat pertumbuhan dan perkembangan tindak pidana korupsi di Indonesia sudah menjadi suatu fenomena yang sejak dulu sulit dibantah dengan argumentasi apapun. Perilaku menyimpang tersebut tidak saja telah berlangsung secara sistematis, dan bersifat institusional, melainkan juga telah masuk kedalam wilayah institusi peradilan pidana yang semestinya berdiri sebagai contoh dan sebagai subjek dari pemberantasan korupsi. Achmad Zainuri mengungkapkan korupsi di Negara ini merambah pada semua lini bagaikan gurita. Penyimpangan ini bukan saja merasuki kawasan yang sudah dipersepsi publik sebagai sarang korupsi, tetapi juga menyelusuri semua lorong- lorong instansi yang tidak terbayangkan sebelumnya bahwa disana ada korupsi. Satu persatu skandal keuangan di berbagai instansi Negara terbongkar. Komisi Pemilihan Umum, yang dipenuhi aktivis demokrasi, akademisi, dan guru besar, juga 
tidak steril dari wabah korupsi. ${ }^{1}$ Pandangan seperti itu tidak jauh berbeda dengan Marwan Effendy yang menyatakan bahwa korupsi di Indonesia seperti tidak habis-habisnya, semakin ditindak semakin meluas, bahkan perkembangannya terus meningkat dari tahun ke tahun, baik dalam jumlah kasus, jumlah kerugian Negara maupun kualitasnya. Akhir-akhir ini nampak makin terpola dan sistematis, lingkupnya juga telah menyentuh keseluruh aspek kehidupan masyarakat dan lintas batas Negara. Atas dasar hal tersebut, korupsi secara nasional disepakati tidak saja sebagai "extraordinary crime", tetapi juga sebagai kejahatan transnasional. ${ }^{2}$ Kondisi ini pun kian parah dengan adanya kasus korupsi yang melibatkan institusi Mahkamah Konstitusi (MK) dengan keterlibatan ketua MK Akhil Mochtar.

Sejak era reformasi tuntutan masyarakat untuk memperbaiki sistem pengawasan di tubuh aparat penegak hukum sangat kuat. Tuntutan ini telah direspon oleh DPR dan Presiden sebagai pembuat undang-undang dengan mengamanatkan pembentukan lembaga pengawas eksternal baik untuk kepolisian maupun kejaksaan maupun hakim di tingkat pengadilan. Sementara itu aparat penegak hukum yang lain merespon tuntutan tersebut dengan memperbaiki sistem pengawasan internal secara strategis dengan harapan untuk dapat memenuhi tuntutan tersebut. Masyarakat tetap meragukan efektivitas lembaga pengawas internal ini karena adanya ketidak percayaan terhadap solidaritas korps yang kuat serta budaya penegakan hukum yang cenderung tertutup. Lembaga pengawas eksternal diharapkan mampu menepis kelemahan tersebut tetapi ternyata tidak berdaya karena tidak didesain dan tidak diberi wewenang yang memadai. Kedudukan komisi pengawas eksternal baik Kompolnas maupun komisi kejaksaan serta komisi judisial hanya berada di pusat, sehingga tidak mampu secara maksimal menampung

1 Achmad Zainuri, 2007, Akar Kultural Korupsi di Indonesia, Cahaya BaruSawangan, Depok, hal.15.

2 Marwan Efendy, 2007, Pengadilan Tindak Pidana Korupsi, Lokakarya Anti-Korupsi Bagi Jurnalis, Surabaya, hal. 1. 
pengaduan penyalahgunaan wewenang yang terjadi di daerah. Salah satu yang dianggap menjadi bagian dari sumber penyimpangan menurut Tjandra Sridjaja Pradjonggo yang dilakukan oleh penegak hukum adalah karena keterbatasan Negara dalam membiayai penegakan hukum, baik untuk memenuhi kebutuhan operasional penegakan hukum maupun menjamin kesejahteraan personil aparat penegak hukum. Persoalan ini bahkan selalu dijadikan legitimasi bagi praktik- praktik penyalahgunaan wewenang karena seolah aparat penegak hukum ditolerir untuk mencari sumber pendapatan dari luar APBN yang akibatnya banyak kita saksikan aparat penegak hukum menjadi pelindung suatu sindikat kejahatan, memeras pencari keadilan dan lain-lain. Perilaku tersebut diantaranya juga dapat dikategorikan sebagai tindak pidana korupsi. ${ }^{3}$

\section{B. Dasar Hukum Pemberatasan Korupsi}

Mengingat masalah Korupsi adalah masalah yang dari dulu butuh perhatian yang sangat serius, sehingga perlu adanya penangan yang khusus. Bukan itu saja untuk memberantasnya butuh undang-undang yang khusus juga. Penanganan masalah Korupsi telah di mulai ketika seluruh wilayah Negara Republik Indonesia dinyatakan dalam keadaan perang yaitu atas dasar Undang-undang nomor 74 tahun 1957 jo Undang-undang nomor 79 tahun 1957 dalam rangka pemberantasan tindak pidana korupsi telah dikeluarkan peraturan Penguasa Perang Pusat/Kepala Staf Angkatan Darat tanggal 16 April 1958 Nomor Prt/Peperpu/013/1958 serta peraturan-peraturan pelaksanaannya dan Peraturan Penguasa Perang Pusat/Kepala Staf Angkatan Laut tanggal 17 April 1958 Nomor Prt/Z/I/7. Oleh karena peraturan Penguasa Perang Pusat tersebut hanya berlaku untuk sementara, maka pemerintah Republik Indonesia menganggap bahwa Peraturan Penguasa Perang Pusat yang dimaksud perlu diganti dengan 
peraturan perundang-undangan yang berbentuk undangundang.

Dengan adanya keadaan yang mendesak dan perlunya diatur segera tindak pidana Korupsi, penggantian Peraturan Penguasa Perang Pusat tersebut ditetapkan dengan perundang- undangan yang berbentuk Peraturan Pemerintah Pengganti Undang-Undang, yaitu dengan peraturan pemerintah Pengganti undang-undang Nomor 24 Tahun 1960 Tentang Pengusutan, Penuntutan, dan Pemeriksaan Tindak Pidana Korupsi, yang kemudian atas dasar Undang-Undang Nomor 1 Tahun 1960 Tentang Pengusutan, Penuntutan, Dan Pemeriksaan Tindak Pidana Korupsi. Didalam penerapannya ternyata Undang-undang Nomor 24 Tahun 1960 masih belum mencapai hasil seperti yang diharapkan sehingga terpaksa diganti lagi dengan Undang-Undang Nomor 3 Tahun 1971 Tentang Pemberantasan Tindak Pidana Korupsi.

Setelah lebih dari dua dasawarsa berlaku, ternyata Undang-Undang Nomor 3 Tahun 1971 tersebut sudah tidak sesuai lagi dengan perkembangan kebutuhan hukum dalam masyarakat, apalagi dengan terjadinya praktik-praktik korupsi, kolusi, dan nepotisme yang melibatkan para penyelenggara Negara dengan para penguasa. Oleh karena itu, sudah sewajarnya jika kemudian MPR sebagai Lembaga tertinggi Negara saat itu menetapkan TAP. MPR Nomor XI/MPR/1998 Tentang Penyelenggara Negara yang Bersih dan Bebas dari Korupsi, Kolusi, dan Nepotisme yang antara lain menetapkan agar diatur lebih lanjut dengan undang-undang tentang upaya pemberantasan tindak pidana korupsi yang dilakukan dengan tegas, dengan melaksanakan secara konsisten Undang-Undang Tindak Pidana Korupsi.

Atas dasar TAP MPR Nomor XI/MPR/1998 ini, kemudian ditetapkan Undang-Undang Nomor 31 Tahun 1999 tentang Pemberantasan Tindak Pidana Korupsi yang mulai berlaku sejak tanggal 16 Agustus 1999, dan dimuat dalam lembaran Negara Republik Indonesia Tahun 1991 Nomor 140, dan kemudian Undang-undang Nomor 3 Tahun 1971 tantang 
Tindak Pidana Korupsi dinyatakan tidak berlaku lagi. Namun kemudian diadakan perubahan terhadap Undang-Undang Nomor 31 Tahun 1999 dengan menetapkan Undang-undang Nomor 20 Tahun 2001 tentang perubahan atas Undang-Undang Nomor 31 Tahun 1999 tentang Pemberantasan Tindak Pidana Korupsi dan dimuat dalam lembaran Negara Republik Indonesia Tahun 2001 Nomor 134 yang mulai berlaku sejak tanggal 21 Nopember 2001.

Sehubungan dengan keseriusan Negara dalam memerangi korupsi maka terdapat serangkaian peraturan perundang-perundangan yang memiliki konsistensi tujuan yang sama dalam memerangi korupsi diantaranya :

1. UU No. 31 Tahun 1999 tentang Pemberantasan tindak pidana korupsi Jo perubahannya UU No. 20 tahun 2001

2. UU No. 28 tahun 1999 tentang penyelenggaraan Negara yang bersih dan bebas KKN (Good Governance)

3. UU No. 15 Tahun 2002 Tentang Tindak Pidana Pencucian uang.

4. UU No.30 Tahun 2002 Tentang Komisi Pembrantasan Tindak Pidana Korupsi.

5. UU No. 7 Tahun 2006 Tentang Pengesahan United Nations Convention Againts Corruption 2003.

6. PP No. 71 Tahun 2000 Tentang Tata Cara Pelaksanan Peran Masyarakat Dan Pemberian Penghargaan Dalam Pencegahan Dan Pemberantasan Tindak Pidana Korupsi.

7. PP No. 68 Tahun 1999 Tentang Tata Cara Pelaksanaan Peran Serta Masyarakat Dalam Penyelenggaraan Negara .

8. Inpres 5/2004 Tentang Percepatan Pemberantasan Korupsi.

Sebagai suatu refleksi bahwa di era orde baru dan juga pada awal reformasi masih jarang kita dengar ada pejabat pemerintahan yang divonis penjara karena melakukan tindak pidana korupsi. Tentunya hal itu terjadi karena belum ada keterbukaan dan pemerintahan masih bersifat kediktatoran yang mana saat itu penanganan tindak pidana korupsi hanya ditangani oleh Instansi Kepolisian dan Kejaksaan yang masih 
bisa diintervensi dan dikontrol pemerintah. Setelah era reformasi dengan kebebasan yang begitu luas dalam hal menyampaikan pendapat dan juga kebebasan terhadap pers. Karena penanganan tindak pidana korupsi pada masa itu dianggap kurang maksimal dan banyaknya pendapat masyarakat yang menginginkan pemberantasan korupsi yang banyak merugikan Negara sehingga dibentuklah Lembaga Khusus yang menangani Tindak Pidana Korupsi yaitu Komisi Pemberantasan Korupsi yang disingkat KPK melalui Undang- Undang Nomor 30 Tahun 2002, sehingga saat ini ada tiga instansi atau lembaga penegak hukum yang menangani kasus- kasus korupsi (kepolisian, kejaksaan dan KPK) sehingga dapat disidangkan di Lembaga Pengadilan.

\section{Penegakan Hukum Tindak Pidana Korupsi}

Setelah terbentuknya Komisi Pemberantasan Korupsi tidak bisa kita pungkiri kalau penanganan tindak korupsi sudah banyak dilakukan, baik itu oleh Komisi Pemberantasan korupsi, Kepolisian dan juga Kejaksaan. Sudah banyak aparat pemerintahan yang di jebloskan ke penjara dari berbagai instansi pemerintahan, mulai dari Hakim, Jaksa, Polisi, Menteri, Gubernur dan juga Bupati, hal itu merupakan dampak positif dari pemberantasan korupsi yang telah dilakukan oleh penegak hukum. Akan tetapi dengan banyaknya kasus Korupsi yang telah ditangani dan telah menjerat berbagai pejabat ternyata tidak menjadi efek jera bagi para pelaku korupsi, bahkan semakin banyak orang yang melakukan korupsi.

Menurut survey Internasional Transparency, Tahun 2012, Indonesia masih menduduki rangking 118 dari 176 Negara, dengan skore 2,8. 
CORRUPTION PERCEPTION INDEX 2012

(TRANSPARENCY INTERNATIONAL). ${ }^{4}$

\begin{tabular}{|c|c|c|c|c|c|c|}
\hline \multirow{2}{*}{ Rank } & \multirow{2}{*}{$\begin{array}{l}\text { Regional } \\
\text { Rank }\end{array}$} & \multirow{2}{*}{ Country/Territorial } & \multirow{2}{*}{$\begin{array}{l}\text { CPI } \\
2012 \\
\text { Score }\end{array}$} & \multicolumn{2}{|c|}{$\begin{array}{l}\text { Confidense } \\
\text { Interval }\end{array}$} & \multirow{2}{*}{$\begin{array}{l}\text { Surveys } \\
\text { Used }\end{array}$} \\
\hline & & & & $\begin{array}{l}\text { Lower } \\
\text { bound }\end{array}$ & $\begin{array}{l}\text { Upper } \\
\text { bound }\end{array}$ & \\
\hline 1. & 1 & New Zealand & 9,4 & 9,1 & 9,5 & 6 \\
\hline 3. & 2 & Singapore & 9,2 & 9,0 & 9,4 & 9 \\
\hline 8. & 3 & Australia & 8,7 & 8,3 & 9,0 & 8 \\
\hline 12. & 4 & Hongkong & 8,2 & 7,9 & 85 , & 8 \\
\hline 17. & 5 & Japan & 7,7 & 7,4 & 8,0 & 8 \\
\hline 37. & 6 & Taiwan & 5,6 & 5,4 & 5,9 & 9 \\
\hline 39. & 7 & Brunei Darussalam & 5,5 & 4,7 & 6,4 & 4 \\
\hline 39. & 7 & South Korea & 5,5 & 5,3 & 5,7 & 9 \\
\hline 43. & 9 & Macao & 5,3 & 3,3 & 6,9 & 3 \\
\hline 49. & 10 & Bhutan & 5,0 & 4,3 & 5,6 & 4 \\
\hline 56. & 11 & Malaysia & 4,5 & 4,0 & 5,1 & 9 \\
\hline 56. & 11 & Samoa & 4,5 & 3,3 & 5,3 & 3 \\
\hline 79. & 13 & China & 3,6 & 3,0 & 4,2 & 9 \\
\hline 84. & 14 & India & 3,4 & 3,2 & 3,6 & 10 \\
\hline 84. & 14 & Thailand & 3,4 & 3,0 & 3,8 & 9 \\
\hline 95. & 16 & Vanuatu & 3,2 & 2,3 & 4,7 & 3 \\
\hline 97. & 17 & Sri Lanka & 3,1 & 2,8 & 3,4 & 7 \\
\hline 99. & 18 & Tonga & 3,0 & 2,6 & 3,3 & 3 \\
\hline 118. & 19 & Indonesia & 2,8 & 2,4 & 3,2 & 9 \\
\hline 111. & 19 & Kiribati & 2,8 & 2,3 & 3,3 & 3 \\
\hline 111. & 19 & Solomon Island & 2,8 & 2,3 & 3,3 & 3 \\
\hline 120. & 22 & Viet Nam & 2,7 & 2,4 & 3,1 & 9 \\
\hline 130. & 23 & Maldives & 2,5 & 1,8 & 3,2 & 4 \\
\hline 139. & 24 & Bangladesh & 2,4 & 2,0 & 2,8 & 7 \\
\hline 139. & 24 & Pakistan & 2,4 & 2,1 & 2,7 & 7 \\
\hline 139. & 24 & Philippines & 2,4 & 2,1 & 2,7 & 9 \\
\hline
\end{tabular}

Kondisi yang demikian dari berbagai Survei Internasional menempatkan Indonesia sebagai salah satu Negara paling korup di dunia. Sebaliknya sebagai pembanding, di Australia, apabila dua ratus tahun lalu pemerintahannya sangat korup, maka kini menjadi salah satu negera paling kurang korup di dunia. Dibawah ini contoh hasil survey salah

http://www.transparency.org, diakses, 29 Oktober 2012. 
satu lembaga internasional mengenai perkembangan korupsi di beberapa Negara Asia, termasuk Indonesia.

Survei Political \& Economic Risk Consultancy (PERC)

The Annual Graft Ranking. ${ }^{5}$

\begin{tabular}{|l|l|l|l|}
\hline \multirow{2}{*}{ Negara } & \multicolumn{3}{|l|}{ Ranking Pada Tahun } \\
\cline { 2 - 4 } & 2004 & 2005 & $\mathbf{2 0 0 6}$ \\
\hline Indonesia & $\mathbf{9 , 2 5}$ & $\mathbf{9 , 1 0}$ & $\mathbf{8 , 1 6}$ \\
\hline Vietnam & $\mathbf{8 , 6 7}$ & $\mathbf{8 , 6 5}$ & $\mathbf{7 , 9 1}$ \\
\hline Philipina & $\mathbf{8 , 3 3}$ & $\mathbf{8 , 8 0}$ & $\mathbf{7 , 8 0}$ \\
\hline Thailand & 7,33 & $\mathbf{7 , 2 0}$ & $\mathbf{7 , 6 4}$ \\
\hline China & 7,33 & 7,68 & 7,58 \\
\hline India & $\mathbf{8 , 9 0}$ & $\mathbf{8 , 6 3}$ & $\mathbf{6 , 7 6}$ \\
\hline Malaysia & $\mathbf{7 , 3 3}$ & $\mathbf{6 , 8 0}$ & $\mathbf{6 , 1 3}$ \\
\hline Taiwan & $\mathbf{6 , 1 0}$ & $\mathbf{6 , 1 5}$ & $\mathbf{5 , 9 1}$ \\
\hline $\begin{array}{l}\text { Korea } \\
\text { Selatan }\end{array}$ & $\mathbf{6 , 6 7}$ & $\mathbf{6 , 5 0}$ & $\mathbf{5 , 4 4}$ \\
\hline Makao & & & $\mathbf{4 , 7 8}$ \\
\hline Hongkong & $\mathbf{3 , 6 0}$ & $\mathbf{3 , 5 0}$ & $\mathbf{1 , 1 3}$ \\
\hline Jepang & $\mathbf{3 , 5 0}$ & $\mathbf{3 , 4 6}$ & $\mathbf{3 , 0 1}$ \\
\hline Singapura & $\mathbf{0 , 5 0}$ & $\mathbf{0 , 6 5}$ & $\mathbf{1 , 3 0}$ \\
\hline
\end{tabular}

Dari tabel diatas dapat dilihat bahwa selama tiga tahun berturut-turut (2004, 2005, 2006) Indonesia menempati urutan pertama Negara terkorup di Asia.Walapun demikian tingkat korupsi di Indonesia selama tiga tahun berturut-turut mengalami penurunan dan itu merupakan bukti dari penanganan dan pemberantasan korupsi yang sedang berjalan oleh penegak hukum.

Selain itu data terbaru hasil survei PERC ini menyebutkan Indonesia mencetak nilai 9,07 dari angka 10 sebagai Negara paling korup 2010. Ini berarti selama 2 tahun terakhir, Indonesia mendapat citra semakin memprihatinkan. Pada tahun 2008, Indonesia menduduki posisi ke-3 dengan nilai tingkat korupsi 7.98 setelah Filipina (tingkat korupsi 9.0) 
dan Thailand (tingkat korupsi 8.0). ${ }^{6}$ Angka tingkat korupsi Indonesia semakin meningkat ditahun 2009 dibanding tahun 2008. Pada tahun 2009, Indonesia „,berhasile menyabet prestasi sebagai Negara terkorup dari 16 Negara surveilances dari PERC 2009. Indonesia mendapat nilai korupsi 8.32 disusul Thailand (7.63), Kamboja $(7,25)$, India $(7,21)$ and Vietnam $(7,11)$, Filipina $(7,0)$. Sementara Singapura $(1,07)$, Hongkong $(1,89)$, dan Australia $(2,4)$ menempati tiga besar Negara terbersih, meskipun ada dugaan kecurangan sektor privat. Sementara Amerika Serikat menempati urutan keempat dengan skor 2,89. Jadi, dari data PERC 2010, maka dalam kurun 20082010, peringkat korupsi Indonesia meningkat dari 7.98 (2008.),

8.32 (2009) dan naik menjadi 9.07 (2010) dibanding dengan 16 Negara Asia Pasifik lainnya. ${ }^{7}$

Tingginya angka korupsi di Indonesia seperti digambarkan pada tabel dan data yang diuraikan tersebut di atas disebabkan tidak hanya terjadi di tingkat elit, namun dapat dipastikan masalah ini terdapat hampir diseluruh lapisan Institusi Negara ini. Tingkat korupsi di masingmasing lapisan tersebut juga beragam, mulai dari korupsi yang jumlahnya kecil-kecilan hingga korupsi besar-besaran yang jumlahnya dapat mencapai angka trilyunan rupiah. Korupsi disamping melibatkan kekuasaan juga melibatkan masyarakat pada umumnya. Korupsi membebani mayoritas masyarakat Indonesia terutama masyarakat miskin. Perbuatan korupsi dapat menciptakan resiko ekonomi-makro yang tinggi, membahayakan kestabilan keuangan, serta mengkompromikan keamanan dan hukum serta ketertiban umum. ${ }^{8}$

6 http://nusantaranews.wordpress.com/2010/03/09/prestasi-terus-naikindonesia-negara-terkorup-asia-2010/. Okezone, 11 Maret 2008. Diakses 29 Oktober 2013.

7 Ibid. 
8 Tjandara Sridjaja Pradjonggo, Op. Cit., hal.9. 
Mohammad Jasin mengemukakan lima hal penyebab utama korupsi di Indonesia, di antaranya :

1. Rendahnya integritas dan profesionalisme.

2. Lemahnya komitmen dan konsistensi penegakan hukum dan peraturan perundangan.

3. Adanya peluang di lingkungan kerja tugas jabatan dan lingkungan masyarakat yang mendukung timbulnya korupsi.

4. Sikap yang tamak, lemahnya keimanan, kejujuran, dan rasa malu.

5. Sistem penggajian yang tidak professional. ${ }^{9}$

Seperti sudah dijelaskan sebelumnya bahwa korupsi tersebut tidak hanya terjadi di tingkat pusat, akan tetapi sudah banyak kasus korupsi yang terjadi di daerah-daerah baik ditingkat provinsi maupun kabupaten/kota. Kurangnya pengawasan dan juga sistem politik demokrasi langsung yang banyak menghabiskan biaya secara pribadi dan kelompok, sehingga intensitas korupsi kian meningkat. Olehnya itu sebagaimana fakta yang disampaikan Koordinator Investigasi dan Advokasi FITRA (Forum Indonesia untuk Transparansi Anggaran), Uchok Sky Khadafi, dalam rilis yang diterima Tribunnews.com, Senin (1/10/2012). Dari kerugian Negara 2005 hingga 2011, ternyata banyak yang belum dikembalikan oleh pemprov kepada kas Negara. Berikut peringkat provinsi terkorup berdasarkan kerugian Negara dan kasus: ${ }^{10}$

1. DKI Jakarta, Rp 721, 5 miliar, 715 kasus

2. Aceh $\mathrm{Rp} 669,8$ miliar dan 620 kasus

3. Sumatera Utara, Rp 515,5 miliar, 334 kasus

4. Papua, Rp 476,9 miliar, 281 kasus

5. Kalimantan Barat, Rp 289,8 miliar, 334 kasus

6. Papua Barat, $\mathrm{Rp} 169$ miliar, 514 kasus

7. Sulawesi Selatan, Rp 157,7 miliar, 589 kasus

9 Ibid.

10 http://www.tribunnews.com/nasional/2012/10/01/ini-dia-peringkatprovinsi-terkorup-di-indonesia. Diakses 29 Oktober 2013. 
8. Sulawesi Tenggara, Rp 139,9 miliar, 513 kasus

9. Riau Rp 125,2 miliar, 348 kasus

10. Bengkulu, Rp 123,9 miliar, 257 kasus

11. Maluku Utara, Rp 114,2 miliar, 732 kasus

12. Kalimantan Timur, Rp 80,1 miliar, 244 kasus

13. Sumatera Selatan, Rp 56,4 miliar, 239 kasus

14. Nusa Tenggara Barat, Rp 52,8 miliar, 307 kasus

15. Sulawesi Tengah, Rp 52,8 miliar, 294 kasus

16. Sulawesi Barat, Rp 51,3 miliar, 335 kasus

17. Gorontalo, Rp 48,8 miliar, 203 kasus

18. Maluku, Rp 47,8 miliar, 326 kasus

19. Nusa Tenggara Timur, Rp 44,4 miliar, 219 kasus

20. Jawa Barat, Rp 32,4 miliar, 363 kasus

21. Lampung, Rp 28,4 miliar, 181 kasus

22. Sumatera Barat, Rp 27,4 miliar, 188 kasus

23. Kalimantan Selatan, Rp 22,8 miliar, 221 kasus

24. Kalimantan Tengah, Rp 21,4 miliar, 153 kasus

25. Banten, Rp 20,1 miliar, 207 kasus

26. Kepulauan Riau, Rp 16,1 miliar, 109 kasus

27. Sulawesi Utara, Rp 16 miliar, 227 kasus

28. Jambi, Rp 15,8 miliar, 172 kasus

29. Jawa Timur, Rp 11,424 miliar, 153 kasus

30. Jawa Tengah, Rp 10,4 miliar, 145 kasus

31. Bali, Rp 6,2 miliar, 81 kasus

32. DIY, Rp 4,7 miliar, 23 kasus

33. Kepulauan Bangka Belitung, Rp 1, 9 miliar, 76 kasus

Dari data FITRA terhadap rangking daerah-daerah di Indonesia terkorup di atas maka dapat dilihat bahwa Maluku menempati urutan 18 besar dari 33 provinsi di Indonesia pada tahun 2005 sampai pada tahun 2011 dengan besar kerugian Negara Rp 47,8 miliar dari 326 kasus. Namun demikian pada rilis terbaru dari data FITRA tahun 2013 Maluku kini menempati urutan ke 12 ini menandaakan adanya peningkatan 
prestasi korupsi di Propinsi Maluku, dapat terlihat dalam urutan sebagai berikut :11

1. Provinsi Sumatera Utara Rp400,100,810,000 (278 kasus)

2. Aceh Rp308,333,807 (387 kasus)

3. Papua Barat Rp207,333,870,000 (478 kasus)

4. DKI Jakarta Rp207,395,680,000 (967 kasus)

5. Papua $191,122,680,000$ (355 kasus)

6. Lampung Rp182,346,440,000 (264 kasus)

7. Riau Rp109,290,820,000 (375 kasus)

8. Sulawesi Selatan Rp79,428,720.000 (242 kasus)

9. Kalimantan Barat Rp58,991,610,000 (330 kasus)

10. Maluku Utara Rp55,055,550,000 (750 kasus)

11. Sulawesi Tenggara Rp53,705,720,000 (454 kasus)

12. Maluku Rp47,077,430.000 (387 kasus)

13. Sumatera Selatan Rp40,363,210,000 (431 kasus)

14. Jawa Barat Rp39,760,140,000 (420 kasus)

15. Jambi Rp39,709,820,000 (147 kasus)

16. Sulawesi Barat Rp39,578,780,000 (327 kasus)

17. Sumatera Barat Rp38,147,540,000 (242 kasus)

18. Bengkulu Rp34,332,030,000 (203 kasus)

19. Nusa Tenggara Timur Rp28,020,190,000 (285 kasus)

20. Sulawesi Tengah Rp26,505,330,000 (234 kasus)

21. Gorontalo Rp24,307,860,000 (255 kasus)

22. Jawa Tengah Rp22,940,620,000 (110 kasus)

23. Bali Rp21,507,660,000 (66 kasus)

24. Kalimantan Timur Rp18,809,760,000 (251 kasus)

25. Kepulauan Riau Rp15,190,210,000 (155 kasus)

26. Sulawesi Utara Rp 14,471,390,000 (208 kasus)

27. Banten Rp 10,203,430,000 (130 kasus)

28. Kalimantan Selatan Rp7,833,060,000 (184 kasus)

29. Nusa Tenggara Barat Rp7,814,960,000 (179 kasus)

30. Kalimantan Tengah Rp5,616,030,000 (166 kasus)

31. Kepulauan Bangka Blitung Rp2,298,720,000 (89 kasus)

32. D.I. Yogyakarta Rp1,897,450,000 (89 kasus)

$11 \quad$ Data

FITRA,

2013, http://indonesiatimurvoice.blogdetik.com/2013/08/13/versi-fitra 
Sebagai daerah kepulauan dibandingkan dengan daerah lainnya yang ada di Indonesia penanganan perkara tindak pidana korupsi di Provinsi Maluku boleh dikatakan cukup rumit. Dalam Tahun 2012 saja tercatat perkara korupsi yang sudah ditangani pihak Kejaksaan wilayah Maluku terbilang cukup banyak perkara. Ini tentu sangat membanggakan bagi penegakan hukum kasus korupsi di Maluku, karena dengan kondisi serta karakteristik wilayah yang 96,4 \% terdiri dari laut dan 3,6\% adalah daratan, disamping tantangan faktor cuaca yang seringkali berubah-ubah membuat lembaga penegak hukum ini tidak pernah mengenal lelah untuk melakukan upaya penanggulangannya. Selain itu, penanganan perkara korupsi juga ditangani oleh penyidik dari Direktorat Reserse dan Kriminal Khusus Polda Maluku dan Pengadilan Tindak Pidana Korupsi, di mana selama tahun 2012 - 2013 tercatat kurang lebih 17 perkara korupsi yang diperiksa dan diputus oleh Pengadilan Tipikor. ${ }^{12}$

Berbagai upaya yang dilakukan oleh pihak lembagalembaga penegak hukum tersebut di atas tentunya merupakan sesuatu hal yang patut dibanggakan. Betapa tidak, karena temyata berbagai kasus korupsi di Maluku telah banyak mengalami penurunan dibandingkan dengan tahun-tahun sebelumnya. Ini tentu merupakan wujud kerja keras dari berbagai pihak, termasuk partisipasi masyarakat dan lembaga swadaya masyarakat. Pada lain pihak, tidak dapat dipungkiri bahwa ternyata tindak pidana korupsi di Indonesia memang semakin sulit untuk diatasi.

Olehnya itu dalam memerangi korupsi ini, seperti halnya yang terjadi di berbagai daerah di Indonesia, Kabupaten Buru walaupun umur kabupaten ini masih tergolong muda namun telah terdapat kasus-kasus korupsi (pelaku tindak pidana

12 Ahmad Latupono, Tesis, 2012, Efektifitas Penanganan Perkara Tindak Pidana Korupsi Pada Pengadilan Tindak Pidana Korupsi Di Wilayah Kepulauan, Unpatti, Ambon hal.2. 
korupsi) yang sudah terjadi di instansi-instansi pemerintahan. Dari beberapa instansi pemerintah daerah Kabupaten buru yang telah terindikasi melakukan tindak pidana korupsi diantaranya pada Dinas Pendidikan dan Kebudayaan Kabupaten Buru, Dinas Kesehatan, Dinas Pertanian dan juga Dinas Tenaga Kerja Dan Transmigrasi. Yang mana tahapannya sudah dalam proses pemeriksaan oleh kepolisian. Sehingga perlu untuk dilakukan pengkajian secara yuridis terhadap proses penegakan hukum dalam kasus tindak pidana korupsi di Kabupaten Buru.

Dengan demikian, sejalan dengan penjelasan tersebut maka penulis pada penulisan buku ini akan mencoba membahas mengenai penegakan hukum terhadap pelaku tindak pidana korupsi di Kabupaten Buru. 


\section{BAB II \\ SISTEM NEGARA HUKUM}

Secara konseptual agar menelusuri lebih jauh terhadap tindak pidana korupsi dalam sistem peradilan pdana oleh penegak hukum di Kabupaten Buru, maka ada beberapa teori yang dapat digunakan.

Namun sebelumnya dapat dijelaskan bahwa secara historis dilihat dari sejarahnya konsepsi korupsi mulai berkembang di barat pada permulaan abad ke-19, yaitu setelah adanya revolusi Perancis, Inggris, dan Amerika), yakni ketika prinsip pemisahan antara keuangan umum/Negara dan keuangan pribadi mulai diterapkan. Korupsi sendiri berasal dari bahasa latin corruptio atau corruptus, yang berarti perbuafan busuk, buruk, bejat, tidak jujur, dapat disuap, tidak bermoral, menyimpang dari kesucian dan kata-katai atau ucapan yang menghina atau memfitnah. Corruptio berasal dari kata corrumpere" suatu kata latin yang lebih tua. Dari bahasa latin itulah turun ke banyak bahasa Eropa seperti Inggris yaitu corruption, corupt; perancis yaitu cornrption; dan Belanda yaitu corruptie, korcuptie. Dari bahasa Belanda inilah kata itu turun ke bahasa lndonesia yaitu korupsi. ${ }^{13}$ Perkataan "corruption", yang berarti kerusakan. Di samping itu, perkataan korupsi dipakai pula untuk menunjuk keadaan atau perbuatan yang busuk. Korupsi banyak disangkutkan kepada ketidak jujuran seseorang dalam bidang keuangan. ${ }^{14}$

Substansi penanganan tindak pidana korupsi, maka yang perlu diperhatikan dalam penanggulangan kejahatan pada umumnya adalah faktor-faktor penyebab korupsi yang antara lain mencakup berbagai dimensi' baik dari bidang moral, sosial, ekonomi, politik, budaya administrasi, dan sebagainya. Menghadapi faktor-faktor penyebab korupsi tersebut, perangkat

13 Andi Hamzah, 2005, Pemberantasan Korupsi, Jakarta : PT. Raja Grafindo persada. hal. 4. 
14 Sudarto, 1986, Hukum dan Hukum Pidana, Bandung, Alumni, hal. 115. 
hukum bukan merupakan alat yang efektif untuk menanggulangi korupsi. upaya penanggulangan korupsi tidak dapat dilakukan hanya dengan menggunakan perangkat hukum. Keterbatasan kemampuan hukum pidana itu, menurut Barda Nawawi Ariefi, disebabkan hal-hal berikut : ${ }^{15}$

1. Sebab-sebab terjadinya kejahatan (khususnya korupsi) sangat kompleks dan berada di luar jangkauan hukum pidana.

2. Hukum pidana hanya merupakan bagian kecil (subsistem) dari sarana kontrol sosial yang tidak mungkin mengatasi masalah kejahatan sebagai masalah kemanusiaan dan kemasyarakatan yang sangat kompleks (sebagai masalah sosiopsikologis, sosiopolitik, sosioekonomi, sosiokultural, dan sebagainya).

3. Penggunaan hukum pidana dalam menanggulangi kejahatan hanya merupakan "kurieren am symptom" (penanggulangan/pengobatan gejala), oleh karena itu, hukum pidana hanya merupakan 'pengobatan simptomatik" dan bukan "pengobatan kausatif.

4. Sanksi hukum pidana hanya merupakan "remedium" yang mengandung sifat kontradiktif/paradoksal dan mengandung unsur-unsur serta efek sampingan yang negatif.

5. Sistem pemidanaan bersifat fragmentair dan individual/personal, tidak bersifat structural/fungsional.

6. Keterbatasan jenis sanksi pidana dan sistem perumusan sanksi pidana yang bersifat kaku dan imperativ.

7. Bekerjanya/berfungsinya hukum pidana memerlukan sarana pendukung yang lebih bervariasi dan lebih menuntut "biaya tinggi.

Sehingga berdasarkan penjelasan di atas dapat diasumsikan bahwa disamping penanggulangan korupsi dalam proses penegakan hukum melalui sarana hukum pidana, kebijakan penanggulangan tindak pidana korupsi juga harus diusahakan

15 Ibid., hal. 86. 
dan diarahkan pada usaha-usaha untuk mencegah, menangani dan menghapus faktor-faktor yang berpotensi menjadi penyebab terjadinya korupsi serta mengoptimalkan sistem penegakan hukum terhadap pelaku tindak pidana korupsi secara tegas. Demikian, maka dapat diuraikan konsep teoretik dalam mendukung penelitian ini adalah sebagai berikut:

\section{A. Teori Negara Hukum}

Pada awalnya konsep Negara hukum sebenarnya dimulai sejak Plato mengemukakan penyelenggaraan Negara yang baik, yakni Negara yang didasarkan pada pengaturan hukum. ${ }^{16}$ Gagasan ini kemudian didukung oleh Aritoteles, muridnya yang menulis buku "Politea", dimana menurutnya suatu Negara yang baik ialah Negara yang diperintah dengan konstitusi dan berkedaulatan hukum. Karena itu terdapat tiga unsur pemerintahan yang berkonstitusi, yakni : Pertama, pemerintahan dilaksanakan untuk kepentingan umum ; Kedua, pemerintahan dilaksanakan menurut hukum yang berdasarkan pada ketentuan-ketentuan umum, dan bukan hukum yang dibuat secara sewenang-wenang yang menyampaikan konvensi dan; Ketiga, pemerintahan berkonsitusi berarti pemerintahan yang dilaksanakan atas kehendak rakyat, bukan berupa paksaan atau tekanan yang dilaksanakan pemerintahan despoti. ${ }^{17}$

Padmo Wahjono mengemukakan bahwa Negara Hukum adalah Negara yang menjamin hak-hak asasi. Negara Hukum merupakan pengertian yang ideal sekali dan merupakan syarat mutlak (condition sine quanon). Negara Hukum dianggap sebagai pelengkap dari Negara demokrasi. Lebih lanjut Padmo menyebutkan empat syarat atau unsur Negara Hukum yaitu : 18

1. Mengakui adanya hak asasi manusia

2. Harus ada pemisahan kekuasaan

16 Azhari Tahir, 1992, Negara Hukum, Bulan Bintang, Jakarta, hal. 2.

17 Ridwan HR. 2007, Hukum Administrasi Negara, Raja Grafindo. Jakarta, hal. 2 .

18 Atmosudirdjo Prajudi, 1994, Teori Administrasi, STIALAN, Jakarta, hal. 117. 
3. Pemerintah harus berdasarkan Undang-Undang (wetmatigheid van bestuur)

4. Adanya pengadilan administrasi yang berdiri sendiri.

Mochtar Kusumaatmadja memberikan pengertian Negara Hukum sebagai, Negara yang berdasarkan Hukum, dimana kekuasaan tunduk pada Hukum dan semua orang sama dihadapan hukum . 19 Secara garis besar, Stahl mengariskan bahwa Negara hukum (rechtstaat) memiliki unsurunsur sebagai berikut:20

1. Mengakui dan melindungi hak-hak asasi manusia;

2. Untuk melindungi terhadap hak-hak asasi tersebut maka penyelenggara Negara harus dilakukan pemisahan atau pembagian kekuasaan untuk menjamin hak-hak itu;

3. Dalam menjalankan tugasnya, pemerintahan berdasarkan peraturan perundang-undangan;

4. Jika dalam menjalankan tugasnya berdasarkan perundangundangan pemerintah masih melanggar hak asasi, maka peradilan administrasi yang akan menyelesaikannya.

Pada bagian lainnya Bothink menyatakan bahwa Negara hukum adalah "de staat, waarin de wilsvijhedi van gezagsdragers is beperkt door grenzen van recht", yakni Negara di mana kebebasan kehendak, pemegang kekuasaan dibatasi oleh ketentuan hukum. Olehnya itu Istilah Negara Hukum menunjuk pada sebuah konsep tentang Negara dimana pemerintah dan rakyat bertindak atas dasar hukum dan bukan atas kemauannya semata. Dengan kata lain Negara Hukum adalah Negara yang berdasarkan Hukum, dimana kekuasaan tertinggi dalam Negara tersebut adalah Hukum (Supremasi Hukum). Sehingga dapat mewujudkan Equality before of the Law yang bermakna bahwa, semua orang baik pejabat pemerintah maupun

19 Mochtar Kusumaatmadja, 1995, Pemantapan Cita Hukum dan Asas Hukum Nasional di Masa Kini dan Masa Yang Akan Datang, Makalah, Jakarta. hal. 1. 20 Agus Salim Andi Gadjong, 2007, Pemerintah Daerah Kajian Politik dan Hukum, Ananta. Jakarta, 2007. 
masyarakat biasa adalah sama statusnya menurut pandangan hukum. Unsur ini merupakan hal yang baik sebab tidak ada rasdiskiriminasi subjek hukum dalam hukum. Menurut Prof R. Djokosutono mengatakan bahwa Negara hukum menurut UUD 1945 adalah berdasarkan pada kedaulatan hukum. Hukumlah yang berdaulat. Negara adalah merupakan subjek hukum, dalam arti rechstaat (badan hukum publik). Menurut M. Scheltema ada empat asas atau unsur utama Negara Hukum dan setiap unsur utama diikuti beberapa unsur turunannya sebagai berikut : ${ }^{21}$

1. Asas Kepastian Hukum, yang unsur turunannya adalah :

a. Asas Legalitas

b. Undang-undang yang mengatur mengenai tindakan yang berwenang sedemikian rupa, sehingga warga dapat mengetahui apa yang dapat diharapkan.

c. Undang-Undang Tidak boleh berlaku surut

d. Hak Asasi dijamin dengan Undang-Undang

e. Pengendalian yang bebas dari pengaruh kekuasaan lain

2. Asas Persamaan, yang Unsur turunannya adalah :
a. Tindakan yang berwenang diatur dalam Undang- undang dalam arti materiil
b. Adanya pemisahan kekuasaan

3. Asas Demokrasi, yang unsur turunannya adalah :
a. Hak untuk memilih dan dipilih bagi warga Negara
b. Peraturan untuk badan yang berwenang ditetapkan oleh parlemen
c. Parlemen mengawasi tindakan pemerintah

4. Asas Pemerintahan untuk rakyat, yang unsur turunannya adalah :
a. Hak Asasi di jamin dengan Undang-Undang Dasar
b. Pemerintah secara Efektif dan efisien

21 Muhammad Tahir Azhari, 1995, Negara Hukum Indonesia, UI-Press, Jakarta. hal.50. 
Berdasarkan hal tersebut yang dikemukakan diatas, maka Schelma berpendapat Bahwa unsur-unsur utama Negara Hukum satu bangsa dapat berbeda dari bangsa lainnya. Penyebab perbedaan itu adalah latar belakang sejarah suatu bangsa yang berbeda terutama Negara Hukumnya.

Unsur-unsur yang berlaku secara umum bagi setiap Negara Hukum sebagai berikut: 22

1. Adanya suatu sistem pemerintahan Negara yang didasarkan atas kedaulatan rakyat

2. Bahwa pemerintah dalam melaksanaan tugas dan kewajibannya harus berdasar atas hukum dan peraturan perundang-undangan.

3. Adanya jaminan terhadap hak asasi manusia.

4. Adanya pembagian kekuasaan dalam Negara

5. Adanya pengawasan dari dari badan-badan peradilan (rechterlicke controle) yang bebas dan mandiri, dalam arti lembaga peradilan tersebut benar-benar tidak memihak dan tidak berada di bawah pengaruh Eksekutif.

6. Adanya peran yang nyata dari anggota-anggota masyarakat atau warga Negara untuk turut serta mengawasi perbuatan dari pelaksanaan kebijakan yang dilaksanakan oleh pemerintah.

Konsep Rechsstaats dan Rule of Law secara prinsip banyak memiliki kesamaan, diantaranya menghendaki penyeleng- garaan pemerintahan berdasarkan Hukum, serta adanya pengakuan dan jaminan terhadap hak-hak asasi. Perbedaan antara keduanya berkaitan dengan teknis hukumnya, sehingga pembatasan kekuasaan pemerintah dilakukan melalui hukum tertulis. Hal ini menempatkan peraturan perundang-undangan sebagai sumber hukum utama, bahkan hakim di kenal "Corong Undang-Undang" begitu juga dengan lembaga susunan lembaga peradilannya, dalam Rechsstaats dipandang perlu adanya peradilan khusus yang mengadili sengketa antara 
pemerintah dengan rakyat. Sebaliknya pada Rule Of Law Hukum lebih berkembang melalui Yurisprudensi (putusan hakim), dimana hakim lebih memilih kebebasan dalam menggali Hukum yang hidup di masyarakat (The Living Law).

Dalam penjelasan UUD 1945 dikatakan bahwa Negara Indonesia berdasar atas hukum (rechstaat) tidak berdasarkan kekuasaan belaka (machstaat) oleh karena itu Negara tidak boleh melaksanakan aktivitasnya atas dasar kekuasaan belaka, tetapi harus berdasarkan Hukum Sehingga indikasi bahwa Indonesia adalah menganut konsep welfare state terdapat pada kewajiban pemerintah untuk mewujudkan tujuan-tujuan Negara, sebagaimana yang termuat dalam alinea ke empat UUD 1945, yaitu melindungi segenap bangsa indonesia dan seluruh tumpah darah indonesia, memajukan kesejahteraan umum, mencerdaskan kehidupan bangsa, dan melaksanakan ketertiban dunia. Tujuan-tujuan ini di upayakan perwujudannya melalui pembangunan yang dilakukan secara bertahap dan berkesinambungan dalam program jangka pendek, menengah dan panjang. ${ }^{23}$

Pemerintahan berdasar atas sistem konstitusional (hukum dasar) tidak bersifat absolutime (kekuasaan yang terbatas), karena kekuasaan eksekutif dan administrasi, di Indonesia berada dalam satu tangan, yaitu ada pada presiden maka administrasi harus berdasar atas sistem konstitusional tidak bersifat absolut. Artinya adiministarasi dalam menjalankan tugasnya dibatasi oleh peraturan perundangan. ${ }^{24}$

Dari uraian diatas, secara prinsip indonesia adalah suatu Negara yang berdasarkan atas Hukum dan untuk itu dapat di kemukakan dua pemikiran: ${ }^{25}$

1. Bahwa kekuasaan tertinggi di dalam Negara Indonesia ialah Hukum yang dibuat oleh rakyat melalui wakilwakilnya di

23 Ibid., hal. 3.

24 C.S.T. Kansil, dan Christine S.T. Kansil, 1997, Hukum Tata Negara Republik Indonesia 1, Penerbit Rineka Cipta, Jakarta. hal 87 -89.

25 Padmo Wahyono, 1982, Negara Republik Indonesia, CV.Rajawali, Jakarta. hal.17-18. 
lembaga legislative. Jadi suatu kedaulatan Hukum sebagai penjelma lebih lanjut dari paham kedaulatan rakyat.

2. Bahwa system pemerintahan Negara atau cara-cara pengendalian Negara memerlukan kekuasaan (power), namun tidak ada suatu kekuasaanpun di Indonesia yang tidak berdasarkan atas Hukum.

\section{B. Teori Sistem Hukum}

Lawrence M. Friedman menyebutkan berhasil atau tidaknya Penegakan hukum bergantung pada tiga unsur yakni: struktur, substansi, dan budaya hukum, satu sama lain memiliki hubungan kuat. 26

1. Substansi Hukum adalah norma (aturan, keputusan) hasil dari produk hukum .

2. Struktur Hukum diciptakan oleh sistem hukum yang mungkin untuk memberikan pelayanan dan penegakan hukum.

3. Budaya hukum adalah ide, perilaku, keinginan, pendapat dan nilai-nilai yang berkaitan dengan hukum ( positif / negatif ).

Substansi hukum dapat dikatakan sebagai salah satu faktor yang memberikan kontribusi dalam terjaninya suatu kejahatan apabila substansi tersebut lemah atau kabur maka memberikan peluang yang besar terhadap terjadinya pelanggaran hukum. Sebagai misal kasus korupsi, kasus ini terjadi karena substansi hukum mudah diciptakan untuk korupsi. Cara sederhana, menjadikan norma hukum yang tidak jelas atau kabur. Substansi hukum yang tidak jelas bukan hanya mudah untuk melakukan korupsi, tetapi juga memberikan kesempatan yang luas untuk aparat penegak hukum untuk "frizzing" sesuai dengan masing-masing kepentingan.

26 Friedman, M. 2001. Lawrence, American Law An Introduction, Second Edition (Hukum Amerika Sebuah Pengantar, Penerjemah Wishnu Basuki, Penerbit PT. Tatanusa, Jakarta, e-USU Repository (C2004 Universitas Sumatera Utara. hal. 78. 
Struktur Hukum/Pranata Hukum: Dalam teori Lawrence Meir Friedman hal ini disebut sebagai sistem Struktural yang menentukan bisa atau tidaknya hukum itu dilaksanakan dengan baik. Struktur hukum berdasarkan UU No. 8 Tahun 1981 meliputi; mulai dari Kepolisian, Kejaksaan, Pengadilan dan Badan Pelaksana Pidana (Lapas). Kewenangan lembaga penegak hukum dijamin oleh undang-undang. Sehingga dalam melaksanakan tugas dan tanggungjawabnya terlepas dari pengaruh kekuasaan pemerintah dan pengaruh-pengaruh lain. Namun teori tersebut banyak diselewengkan. Buktinya banyak penegak hukum yang korup dan jika ketahuan melakukan korupsi mereka dihukum sangat singkat. Penting untuk melakukan reformasi yang sangat mendasar untuk sistem pengadilan, tidak hanya reformasi kelembagaan atau mekanisme reformasi prosedural , tetapi juga tentang kepribadian dan kerja aparat pengadilan dan perilaku masyarakat hukum yang kurang optimal . Penegakan hukum progresif menjadi prioritas alternatif yang wajib digunakan untuk kasus korupsi seperti ini. karena penanggulangan kasus cenderung monoton sehingga Indonesia akan menjadi surga bagi koruptor. Dalam penegakan hukum progesif diperlukan penegak hukum yang memiliki integritas tinggi juga moralitas.

Kultur hukum menurut Lawrence Meir Friedman adalah: ${ }^{27}$ Sikap manusia terhadap hukum dan sistem hukumkepercayaan, nilai, pemikiran, serta harapannya. Kultur hukum adalah suasana pemikiran sosial dan kekuatan sosial yang menentukan bagaimana hukum digunakan, dihindari, atau disalahgunakan. Budaya hukum erat kaitannya dengan kesadaran hukum masyarakat. Semakin tinggi kesadaran hukum masyarakat maka akan tercipta budaya hukum yang baik dan dapat merubah pola pikir masyarakat mengenai hukum selama ini. Secara sederhana, tingkat kepatuhan masyarakat terhadap hukum merupakan salah satu indikator berfungsinya hukum. Masyarakat Indonesia sendiri belum terlalu paham dan patuh dengan proses hukum yang ada.

27 Ibid. 
Pelaksanaan hukum di Indonesia pun belum tampak adil. Korupsi dijadikan sebuah perilaku hukum yang negatif dan dilakukan terus menerus. Untuk mengubah budaya hukum kita harus selalu memahami tentang nilai-nilai, tradisi, kebiasaan, dan segala sikap dominan yang berlaku pada semua aspek hidup.

\section{Teori Penegakan Hukum}

Dari berbagai konsep pemikiran penegakan hukum sering diartikan sebagai upaya menerapkan aturan-aturan atau norma-norma yang bertujuan menjamin adanya kepastian hukum dan keadilan bagi masyarakat dan atau pencari keadilan. Muladi yang merumuskan penegakan hukum sebagai "usaha untuk menegakkan norma-norma dan kaidah-kaidah sekaligus nilai-nilai yang ada di belakang norma hukum itu sendiri". Dalam penjelasannya, Muladi mengatakan bahwa dalam hal ini, aparat penegak hukum wajib memahami benar- benar jiwa hukum (legal spirit) yang mendasari peraturan hukum yang harus ditegakkan, terkait dengan berbagai dinamika yang terjadi dalam proses pembuatan perundang- undangan (law making process). Radbruch (1961:12-13) sebagaimana dikutip Muladi menegaskan bahwa dalam suatu masyarakat yang tertib, maka (konsep) hukum itu dapat berbeda karena tatanan dari berbagai macam norma- Pada satu sisi, hukum dapat bersifat "ide-ide" (yuridis normatif dan pada sisi lainnya hukum juga bersifat 'kenyataan" (yuridis sosiologis). Jika demikian menurut Muladi, penegakan hukum harus berbasis "spirit of law"', yakni mendasari peraturan hukum yang hendak ditegakkan pada asas-asas hukum, karena hal ini terkait dengan pelbagai dinamika yang terjadi dalam proses pembuatan hukum (law making process). ${ }^{28}$

Penegakan hukum menurut Satjipto Rahardjo penegakan hukum adalah penegakan ide-ide atau konsep-konsep yang abstrak, dan merupakan usaha untuk mewujudkan ide-ide

28 Muladi, 1995, Kapita Selecta System Peradilan Pidana, Penerbit Universitas Diponegoro. Semarang . hal. 97. 
tersebut menjadi kenyataan. Terdapat 5 hal yang mempengaruhi penegakan hukum :29

1. Faktor hukum atau peraturan itu sendiri: Merupakan suatu hal yang sangat vital bahwa peraturan yang dibuat harus sesuai dan relevan terhadap objek hukum yang ada. Jika aturan-aturan itu sendiri tidak mampu merubah keadaan maka hukum yang ada itu dirasa sia-sia di rumuskan.

2. Faktor penegak hukum: Penegak hukum, dalam hal ini ialah aparat yang berfungsi menegakkan hukum, yaitu polisi, TNI, jaksa, MK, dan lembaga hukum lainnya. Pengaruh ini sangat besar dalam menentukan seberapa kuat penegakan hukum dalam suatu Negara, dan seharusnya memang orang-orang yang benar-banar terpilih untuk dapat dipercaya mengembankan amanah sebagai penegak hukum di tengah kekacauan hukum dalam suatu Negara.

3. Faktor sarana dan fasilitas: yang mendukung penegakan hukum sarana dan fasilitas merupakan alat bantu pendukung agar penegakan hukum berjalan lancar, dan terkendali. Di tengah zaman yang semakin modern, kejahatan, dan kriminalitas makin maju juga terjadi , untuk itu diperlukan penyesuaian sarana pada lembaga hukum agar berjalan efektif tanpa kendala.

4. Faktor masyarakat: Masyarakat merupakan objek yang akan dituju untuk menjalankah hukum yang berlau, maka dari itu, ditengah era demokrasi sekarang ini suara masyarakat harus lebih di dengar dalam merumuskan peraturan hukum yang akan dikeluarkan.

5. Faktor kebudayaan: Budaya merupakan suatu kekuatan sosial yang tidak tampak, yang dapat menggerakan orang dalam suatu perkumpulan atau kelompok. Untuk itu diperlukan penyesuaian terhadap budaya yang ada. Khususnya di tengah era desentralisasi yang menunjukan perbedaan budaya pada masing-masing daerah semakin kental. Maka dari itu tugas dari aparat hukum setempat

29 Satjipto Rahardjo, 2010, Penegakan Hukum Progresif, Penernit Buku Kompas, Jakarta. hal. 11. 
untuk lebih tanggap terhadap budaya yang ada dalam rangka penegakan hukum.

Menurut Hamis McRae (1995), bahwa penegakan hukum dilakukan dengan pendayagunaan kemampuan berupa penegakan hukum, dilakukan oleh orang-orang yang betulbetul ahli di bidangnya dan dalam penegakan hukum akan lebih baik jika penegakan hukum mempunyai pengalaman praktek berkaitan dengan bidang yang ditanganinya.

Menurut Joseph Golstein penegakan hukum pidana dapat dibedakan menjadi tiga bagian: 30

Pertama, Total Enforcement yaitu dimana ruang lingkup penegakan hukum pidana sebagaimana yang dirumuskan oleh hukum pidana substantif (substantive law of crimes). Penegakan hukum pidana secara total ini tidak mungkin dilakukan, sebab para penegak hukum termasuk Kepolisian dibatasi secara ketat oleh hukum acara pidana, seperti adanya aturan-aturan tentang penangkapan, penahanan, penggeledahan, penyitaan dan pemeriksaan pendahuluan. Selain itu mungkin terjadi hukum pidana substantif sendiri memberikan batasan-batasan, misalnya dibutuhkannya aduan (klacht delicten) sebagai syarat penuntutan pada delik-delik aduan.

Kedua, Setelah ruang lingkup penegakan hukum yang bersifat total tersebut dikurangi area of no enforcement, maka muncullah suatu bentuk penegakan hukum pidana yang kedua yaitu Full Enforcement. Namun dalam ruang lingkup ini-pun para penegak hukum termasuk Polri tidak bisa diharapkan menegakkan hukum secara maksimal karena adanya berbagai keterbatasan, baik dalam bentuk waktu, sarana-prasarana, kualitas sumberdaya manusia, perundang-undangan dan sebagainya sehingga mengakibatkan dilakukannya discretions. Sehingga menurut Joseph Golstein, yang tersisa adalah Actual Enforcement.

Ketiga, pelaksanaan Actual Enforcement ini pun tidak tertutup kemungkinan untuk terjadinya berbagai 
penyimpangan yang dilakukan oleh aparat penegak hukum termasuk Kepolisian.

Sebagaimana yang dikemukakan oleh La Patra dalam bukunya Analizing the Criminal Justice System, bahwa penegakan hukum pidana sebagai suatu sistem adalah interface, yaitu interaksi, interkoneksi dan interdepedensi sistem peradilan pidana dengan lingkungan yang lebih luas disekitarnya. Hal ini dapat digambarkan dalam suatu skema interface: Interaksi, Interkoneksi dan Inter depedensi Sistem Peradilan Pidana dengan lingkungannya. ${ }^{31}$

Penegakan hukum menurut Soerjono Soekanto, adalah situasi dimana hukum yang berlaku dapat dilaksanakan, ditaati dan berdaya guna sebagai alat kontrol sosial atau sesuai tujuan dibuatnya hukum tersebut.

Faktor-faktor yang mempengaruhi penegakan hukum: 32

1. Hukum/UU /peraturan.

2. Penegak hukum ( pembentuk hukum maupun penerap hukum).

3. Sarana atau fasilitas pendukung.

4. Masyarakat

5. Budaya hukum (legal cultur).

Dalam kelima faktor tersebut dapat dijelaskan bahwa :

1. Undang-undang

Undang-undang dalam arti material adalah peraturan tertulis yang berlaku umum dan dibuat oleh Penguasa Pusat maupun Daerah yang sah (Purbacaraka \& Soerjono Soekanto, 1979). Mengenai berlakunya undangundang tersebut, terdapat beberapa asas yang tujuannya adalah agar undang-undang tersebut mempunyai dampak yang positif.

31 La Patra, 1978, Analizing the Criminal Justice System, LexingtonBooks, Toronto, hal. 56.

32 Soerjono Soekanto, 1983, Beberapa Aspek Sosio Yurudis Masyarakat, Alumni, Bandung, hal. 5. 
Asas-asas tersebut antara lain (Purbacaraka \& Soerjono Soekanto, 1979): 33

1. Undang-undang tidak berlaku surut.

2. Undang-undang yng dibuat oleh penguasa yang lebih tinggi,

3. mempunyai kedudukan yang lebih tinggi pula.

4. Undang-undang yang bersifat khusus menyampingkan undang-undang yang bersifat umum, apabila pembuatnya sama.

5. Undang-undang yang berlaku belakangan, membatalkan undang-undang yan berlaku terdahulu.

6. Undang-undang tidak dapat diganggu guat.

7. Undang-undang merupakan suatu sarana untuk mencapai kesejahteraan spiritual dan materiel bagi masyarakat maupun pribadi, melalui pelestaian ataupun pembaharuan (inovasi).

\section{Penegak Hukum}

Penegak hukum merupakan golongan panutan dalam masyarakat, yang hendaknya mempunyai kemampuan- kemampuan tertentu sesuai dengan aspirasi masyarakat. Mereka harus dapat berkomunikasi dan mendapat pengertian dari golongan sasaran, disamping mampu menjalankan atau membawakan peranan yang dapat diterima oleh mereka.

Ada beberapa halangan yang mungkin dijumpai pada penerapan peranan yang seharusnya dari golongan sasaran atau penegak hukum, Halangan-halangan tersebut, adalah:

a. Keterbatasan kemampuan untuk menempatkan diri dalam peranan pihak lain dengan siapa dia berinteraksi.

b. Tingkat aspirasi yang relatif belum tinggi.

c. Kegairahan yang sangat terbatas untuk memikirkan masa depan, sehingga sulit sekali untuk membuat proyeksi. 
d. Belum ada kemampuan untuk menunda pemuasan suatu kebutuhan tertentu, terutama kebutuhan material.

e. Kurangnya daya inovatif yang sebenarnya merupakan pasangan konservatisme.

Halangan-halangan tersebut dapat diatasi dengan membiasakan diri dengan sikap-sikap, sebagai berikut:

1. Sikap yang terbuka terhadap pengalaman maupun penemuan baru.

2. Senantiasa siap untuk menerima perubahan setelah menilai kekurangan yang ada pada saat itu.

3. Peka terhadap masalah-masalah yang terjadi di sekitarnya.

4. Senantiasa mempunyai informasi yang selengkap mungkin mengenai pendiriannya.

5. Orientasi ke masa kini dan masa depan yang sebenarnya merupakan suatu urutan.

6. Menyadari akan potensi yang ada dalam dirinya.

7. Berpegang pada suatu perencanaan dan tidak pasrah pada nasib.

8. Percaya pada kemampuan ilmu pengetahuan dan teknologi di dalam meningkatkan kesejahteraan umat manusia.

9. Menyadari dan menghormati hak, kewajiban, maupun kehormatan diri sendiri dan ihak lain.

10. Berpegang teguh pada keputusan-keputusan yang diambil atas dasar penalaran dan perhitingan yang mantap. ${ }^{34}$

a. Faktor Sarana atau Fasilitas

Tanpa adanya sarana atau fasilitas tertentu, maka tidak mungkin penegakan hukum akan berjalan dengan lancar. Sarana atau fasilitas tersebut antara lain, mencakup tenaga manusia yang berpendidikan dan 
trampil, organisasi yang baik, peralatan yang memadai, keuangan yang cukup, dan seterusnya.

Sarana atau fasilitas mempunyai peran yang sangat penting dalam penegakan hukum. Tanpa adanya sarana atau fasilitas tersebut, tidak akan mungkin penegak hukum menyerasikan peranan yang seharusnya dengan peranan yang aktual. Khususnya untuk sarana atau fasilitas tesebut, sebaiknya dianut jalan pikiran, sebagai berikut: 35

1) Yang tidak ada-diadakan yang baru betul.

2) Yang rusak atau salah-diperbaiki atau dibetulkan.

3) Yang kurang-ditambah.

4) Yang macet-dilancarkan.

5) Yang mundur atau merosot-dimajukan atau ditingkatkan.

b. Faktor Masyarakat

Penegakan hukum berasal dari masyarakat, dan bertujuan untuk mencapai kedamaian dalam masyarakat. Oleh karena itu, dipandang dari sudut tertentu, maka masyarakat dapat mempengaruhi penegakan hukum tersebut.

Masyarakat Indonesia mempunyai kecendrungan yang besar untuk mengartikan hukum dan bahkan mengidentifikasikannya dengan petugas (dalam hal ini penegak hukum sebagai pribadi). Salah satu akibatnya adalah, bahwa baik buruknya hukum senantiasa dikaitkan dengan pola prilaku penegak hukum tersebut.

c. Faktor Kebudayaan

Kebudayaan (system) hukum pada dasarnya mencakup nilai-nilai yang mendasari hukum yang berlaku, nilai-nilai yang merupakan konsepsi abstrak mengenai apa yang dianggap baik (sehingga dianuti) dan apa yang dianggap buruk (sehingga dihindari). 
Pasangan nilai yang berperan dalam hukum, adalah sebagai berikut : 36

1) Nilai ketertiban dan nilai ketentraman.

2) Nilai jasmani/kebendaan dan nilai rohani / keakhlakan.

3) Nilai kelanggengan / konservatisme dan nilai keba- ruan /inovatisme.

\section{Teori Penanggulangan Kejahatan}

Secara general fenomena korupsi yang muncul dengan menggunakan pemikiran yang rasional dan terorganisir, yang dalam konteks kebijakan hukum dikenal dengan istilah kebijakan kriminal (politic criminal). oleh Marc Ancel dirumuskan bahwa politik criminal adalah "the rational organization of the control of crime by socity. (Marc Ancel, 1965) Menurut Barda Nawawi Arief, definisi ini tidak berbeda dengan pendapat dari Hoefnagels yang berpendapat bahwa "criminal policy is the rational organization of the social reaction to crime". Hal ini berarti dapat dirumuskan bahwa politik kriminal merupakan suatu usaha yang rasional dari masyarakat dalam penanggulangan kejahatan. ${ }^{37}$

Dalam kaitan dengan tindak pidana korupsi, Barda Nawawi Arief berpendapat bahwa masalah korupsi merupakan masalah yang kompleks sifatnya. Dalam kaitan itu, maka ditakatan bahwa: "masalah korupsi terkait dengan berbagai kompleksitas masalah, antara lain masalah moral/sikap mental, masalah pola hidup serta budaya dan lingkungan sosial, masalah kebutuhan/tuntutan ekonomi dan kesenjangan sosial-ekonomi, masalah struktur/sistem ekonomi. masalah sistem/budaya politik, masalah mekanisme pembangunan dan lemahnya birokrasi/prosedur administrasi (termasuk sistem pengawasan) di bidang keuangan dan perayanan publik. Jadi, kausa dan kondisi yang bersifat kriminogen untuk timbulnya korupsi sangatlah luas

36 Ibid.

37 Barda Nawawi Arief 2, Op. Cit., hal. 98. 
(multidimensi), yaitu bisa di bidang moral, sosial, ekonomi, politik, budaya birokrasi/administrasi dan sebagainya". ${ }^{38}$

Lebih lanjut Barda mengatakan bahwa hukum pidana mempunyai keterbatasan dan kelemahan sebagai sarana untuk menanggulangi kejahatan (termasuk pemberantasan tindak pidana korupsi), yaitu: 39

1. Sebab-sebab terjadi kejahatan (khususnya korupsi) sangat kompleks dan berada di luar jangkauan hukum pidana.

2. Hukum pidana hanya merupakan bagian bagian kecil (subsistem) dari sarana kontrol sosial yang tidak mungkin mengatasi masalah kejahatan sebagai masalah kemanusiaan dan kemasyarakatan yang sangat kompleks (sebagai masalah sosiopisikologis, sosiopolitik, sosioekonomi, sosiokultural, dan sebagainya).

3. Penggunaan hukum pidana dalam menanggulangi kejahatan hanya merupakan "kurieren am symptom" (penanggulangan/pengobatan gejala), oleh karena itu, hukum pidana hanya. merupakan "pengobatan simptomatik", dan bukan "pengobatan kausatif.

4. Sanksi hukum pidana hanya merupakan remedium yang mengandung sifat kontradiktif/paradoksar dan mengandung unsur-unsur serta efek sampingan yang negativ.

5. Sistem pemidanaan bersifat fragmentair dan individual/personal, tidak bersifat struktural/fungsional.

6. Keterbatasan jenis sanksi pidana dan sistem perumusan sanksi pidana yang bersifat kaku dan imperativ.

7. Bekerjanya/berfungsinya hukum pidana memerlukan sarana pendukung yang lebih bervariasi dan lebih menuntut biaya tinggi. 
Demikian halnya yang disampaikan oleh Romli Atmasasmita bahwa "pendekatan legalistik yang berorientasi represif hanya merupakan pengobatan yang bersifat simptomatik, dan tidak merupakan sarana hukum yang ampuh untuk memberantas korupsi" sehingga diperlukan pendekatan komprehensif. 40

Oleh karena itu maka korupsi merupakan suatu kejahatan yang oleh E. H. Sutherland menjelaskan bahwa Kejahatan adalah perbuatan yang melanggar UU (ditinjau dari sudut yuridis) sehingga ia menggolongkan perbuatan yang melanggar UU sebagai suatu kejahatan \& jikatidak diatur dalam UU adalah bukan kejahatan. Dan ditambahka oleh Menurut Soedjono Dirjosisworo bahwa kejahatan adalah sebagai perilaku yang merugikan, menjengkelkan dan tidak dapat dibiarkan berlangsung dan apabila berlangsung akan mengakibatkan masyarakat menderita sesuatu yang tidak diinginkan.

Olehnya itu Kejahatan adalah masalah sosial yang dihadapi oleh masyarakat di seluruh negara semenjak dahulu dan pada hakikatnya merupakan produk dari masyarakat sendiri. Kejahatan dalam arti luas, menyangkut pelanggaran dari norma-norma yang dikenal masyarakat, seperti normanorma agama, norma moral hukum. Norma hukum pada umumnya dirumuskan dalam undang-undang yang dipertanggungjawabkan aparat pemerintah untuk menegakkannya, terutama kepolisian, kejaksaan dan pengadilan. Namun, karena kejahatan langsung mengganggu keamanan dan ketertiban masyarakat, maka wajarlah bila semua pihak baik pemerintah maupun warga masyarakat, karena setiap orang mendambakan kehidupan bermasyarakat yang tenang dan damai.

Seperti yang dikemukakan oleh E.H.Sutherland dan Cressey yang mengemukakan bahwa dalam crime prevention

40 Romli Atmasasmita, 1998, Prospek Penangilangan Korupsi Di Indonesia Memasuki Abad ke XXI : Suatu Reoreinlasi atas Kebijakan Hukum Pidana di Indonesia, Pidato Pengukuhan Jabatan Guru Besar Madya dalam Ilmu Hukum pada Fakultas Hukum Universitas Padjajaran, Bandung, 25 September, 1998. 
dalam pelaksanaannya ada dua buah metode yang dipakai untuk mengurangi frekuensi dari kejahatan, yaitu : ${ }^{41}$

Metode untuk mengurangi pengulangan dari kejahatan: Merupakan suatu cara yang ditujukan kepada pengurangan jumlah residivis (pengulangan kejahatan) dengan suatu pembinaan yang dilakukan secara konseptual.

Metode untuk mencegah the first crime: Merupakan satu cara yang ditujukan untuk mencegah terjadinya kejahatan yang pertama kali (the first crime) yang akan dilakukan oleh seseorang dan metode ini juga dikenal sebagai metode prevention (preventif).

Berdasarkan uraian di atas dapat dilihat bahwa upaya penanggulangan kejahatan mencakup aktivitas preventif dan sekaligus berupaya untuk memperbaiki perilaku seseorang yang telah dinyatakan bersalah (sebagai seorang narapidana) di lembaga pemasyarakatan. Dengan kata lain upaya penanggulangan kejahatan dapat dilakukan secara preventif dan represif.

\section{a. Upaya preventif}

Penanggulangan kejahatan secara preventif dilakukan untuk mencegah terjadinya atau timbulnya kejahatan yang pertama kali . Mencegah kejahatan lebih baik daripada mencoba untuk mendidik penjahat menjadi lebih baik kembali, sebagaimana semboyan dalam kriminologi yaitu usaha-usaha memperbaiki penjahat perlu diperhatikan dan diarahkan agar tidak terjadi lagi kejahatan ulangan.

Sangat beralasan bila upaya preventif diutamakan karena upaya preventif dapat dilakukan oleh siapa saja tanpa suatu keahlian khusus dan ekonomis.

Barnest dan Teeters menunjukkan beberapa cara untuk menanggulangi kejahatan yaitu: ${ }^{42}$

1) Menyadari bahwa akan adanya kebutuhan-kebutuhan untuk mengembangkan dorongan-dorongan sosial atau

41 Romli Atmasasmita. 1983, Bunga Rampaian Kriminologi. Rajawali, Jakarta, hal.66.

42 Ibid., hal. 79 
tekanan-tekanan sosial dan tekanan ekonomi yang dapat mempengaruhi tingkah laku seseorang ke arah perbuatan jahat.

2) Memusatkan perhatian kepada individu-individu yang menunjukkan potensialitas kriminal atau sosial, sekalipun potensialitas tersebut disebabkan gangguangangguan biologis dan psikologis atau kurang mendapat kesempatan sosial ekonomis yang cukup baik sehingga dapat merupakan suatu kesatuan yang harmonis .

Menyadari tingginya tingkat kejahatan, maka secara langsung atau tidak langsung mendorong pula perkembangan dari pemberian reaksi terhadap kejahatan dan pelaku kejahatan pada hakikatnya berkaitan dengan maksud dan tujuan dari usaha penanggulangan kejahatan tersebut.

Menurut Hoefnagels (Arief, 1991:2) upaya penanggulangan kejahatan dapat ditempuh dengan cara :43

1) Criminal application: (penerapan hukumpidana)

Contohnya : penerapan Pasal 354 KUHP dengan hukuman maksimal yaitu 8 tahun baik dalam tuntutan maupun putusannya.

2) Preventif without punishment: (pencegahan tanpa pidana)

Contohnya : dengan menerapkan hukuman maksimal pada pelaku kejahatan, maka secara tidak langsung memberikan prevensi (pencegahan) kepada publik walaupun ia tidak dikenai hukuman atau shock therapy kepada masyarakat.

3) Influencing views of society on crime and punishment (mas media mempengaruhi pandangan masyarakat mengenai kejahatan dan pemidanaan lewat mas media).

Contohnya: mensosialisasikan suatu undang-undang dengan memberikan gambaran tentang bagaimana delik itu dan ancaman hukumannya.

43 Barda Nawawi Arief. 1991, Upaya Non dalam Kebijakan Penanggulan Kejahatan, Bahan Seminar Kriminologi. UNDI. Semarang. hal. 2. 


\section{b. Upaya represif}

Upaya represif adalah suatu upaya penanggulangan kejahatan secara konsepsional yang ditempuh setelah terjadinya kejahatan. Penanggulangan dengan upaya represif dimaksudkan untuk menindak para pelaku kejahatan sesuai dengan perbuatannya serta memperbaikinya kembali agar mereka sadar bahwa perbuatan yang dilakukannya merupakan perbuatan yang melanggar hukum dan merugikan masyarakat, sehingga tidak akan mengulanginya dan orang lain juga tidak akan melakukannya mengingat sanksi yang akan ditanggungnya sangat berat.

Dalam membahas sistem represif, tentunya tidak terlepas dari sistem peradilan pidana kita, dimana dalam sistem peradilan pidana paling sedikit terdapat 5 (lima) sub- sistem yaitu sub-sistem kehakiman, kejaksaan, kepolisian, pemasyarakatan, dan kepengacaraan, yang merupakan suatu keseluruhan yang terangkai dan berhubungan secara fungsional.

Upaya represif dalam pelaksanaannya dilakukan pula dengan metode perlakuan (treatment) dan penghukuman (punishment). Lebih jelasnya uraiannya sebagai berikut ini :

1) Perlakuan ( treatment)

Dalam penggolongan perlakuan, penulis tidak membicarakan perlakuan yang pasti terhadap pelanggar hukum, tetapi lebih menitikberatkan pada berbagai kemungkinan dan bermacam-macam bentuk perlakuan terhadap pelanggar hukum sesuai dengan akibat yang ditimbulkannya.

Perlakuan berdasarkan penerapan hukum, menurut Abdul Syani yang membedakan dari segi jenjang berat dan ringannya suatu perlakuan,yaitu : ${ }^{44}$

a) Perlakuan yang tidak menerapkan sanksi-sanksi pidana, artinya perlakuan yang paling ringan

44 Abdulsyani. 1987. Sosiologi Kriminologi. Ramaja Karya, Bandung. hal. 139. 
diberikan kepada orang yang belum telanjur melakukan kejahatan. Dalam perlakuan ini, suatu penyimpangan dianggap belum begitu berbahaya sebagai usaha pencegahan.

b) Perlakuan dengan sanksi-sanksi pidana secara tidak langsung, artinya tidak berdasarkan putusan yang menyatakan suatu hukum terhadap si pelaku kejahatan.

Adapun yang diharapkan dari penerapan perlakuan-perlakuan ini ialah tanggapan baik dari pelanggar hukum terhadap perlakuan yang diterimanya. Perlakuan ini dititikberatkan pada usaha pelaku kejahatan agar dapat kembali sadar akan kekeliruannya dan kesalahannya, dan dapat kembali bergaul di dalam masyarakat seperti sedia kala .

Jadi dapat disimpulkan bahwa perlakuan ini mengandung dua tujuan pokok, yaitu sebagai upaya pencegahan dan penyadaran terhadap pelaku kejahatan agar tidak melakukan hal-hal yang lebih buruk lagi dimaksudkan agar si pelaku kejahatan ini di kemudian hari tidak lagi melakukan pelanggaran hukum, baik dari pelanggaran-pelanggaran yang mungkin lebih besar merugikan masyarakat dan pemerintah.

2) Penghukuman (punishment)

Jika ada pelanggar hukum yang tidak memungkinkan untuk diberikan perlakuan (treatment), mungkin karena kronisnya atau terlalu beratnya kesalahan yang telah dilakukan, maka perlu diberikan penghukuman yang sesuai dengan perundangundangan dalam hukum pidana.

Oleh karena Indonesia sudah menganut sistem pemasyarakatan, bukan lagi sistem kepenjaraan yang penuh dengan penderitaan, maka dengan sistem pemasyarakatan hukuman dijatuhkan kepada pelanggar hukum adalah hukuman yang semaksimal mungkin 
(bukan pembalasan) dengan berorientasi pada pembinaan dan perbaikan pelaku kejahatan.

Seiring dengan tujuan dari pidana penjara sekarang, Sahardjo mengemukakan seperti yang dikutip oleh Abdulsyani sebagai berikut : Menyatakan bahwa tujuan dari pemasyarakatan yang mengandung makna bahwa tidak hanya masyarakat yang diayomi terhadap diulanginya perbuatan jahat oleh terpidana, tetapi juga orang-orang yang menurut Sahardjo telah tersesat diayomi oleh pohon beringin dan diberikan bekal hidup sehingga menjadi kaula yang berfaedah di dalam masyarakat Indonesia. ${ }^{45}$

Penanggulangan kejahatan dapat diartikan secara luas dan sempit. Menurut Sudarto, Dalam pengertian yang luas, maka pemerintah beserta masyarakat sangat berperan. Bagi pemerintah adalah keseluruhan kebijakan yang dilakukan melalui perundang-undangan dan badan-badan resmi yang bertujuan untuk menegakkan norma-norma sentral dari masyarakat. ${ }^{46}$

Peran pemerintah yang begitu luas, maka kunci dan strategis dalam menanggulangi kejahatan meliputi, ketimpangan sosial, diskriminasi nasional, standar hidup yang rendah, pengangguran dan kebodohan di antara golongan besar penduduk. Bahwa upaya penghapusan sebab dari kondisi menimbulkan kejahatan harus merupakan strategi pencegahan kejahatan yang mendasar. ${ }^{47}$

Lain halnya menurut Baharuddin Lopa bahwa "upaya dalam menanggulangi kejahatan dapat diambil beberapa langkah-langkah terpadu, meliputi langkah penindakan (represif) disamping langkah pencegahan

45 Ibid., hal. 141.

46 Sudarto, 1981, Suatu Dilema Dalam Pembaharuan Sistem Pidana Indonesia, Pidato Pengukuhan Guru Besar Tetap Dalam Mata Pelajaran Hukum Pidana Pada Universitas Diponegoro, Semarang 21 Desember 1974. Dalam Beberapa Guru Besar Berbicara Tentang Hukum (Kumpulan Pidato-Pidato Pengukuhan), Bandung Alumni. hal. 114.

47 Arief, 1991, Op. Cit. hal. 4. 
(preventif)." Langkah-langkah preventif menurut Baharuddin Lopa, itu meliputi : 48

a) Peningkatan kesejahteraan rakyat untuk mengurangi pengangguran, yang dengan sendirinya akan mengurangi kejahatan.

b) Memperbaiki sistem administrasi dan pengawasan untuk mencegah terjadinya penyimpanganpenyimpangan.

c) Peningkatan penyuluhan hukum untuk memeratakan kesadaran hukum rakyat.

d) Menambah personil kepolisian dan personil penegak hukum lainnya untuk lebih meningkatkan tindakan represif maupun preventif.

e) Meningkatan ketangguhan moral serta profesionalisme bagi para pelaksana penegak hukum.

Hal tersebut terkait dengan pandangan Jeremy Bentham (2006:307) bahwa yang mengemukakan bahwa "Tujuan hukuman adalah mencegah terjadinya kejahatan serupa, dalam hal ini dapat memberi efek jera kepada pelaku dan individu lain pun untuk berbuat kejahatan." ${ }^{49}$

\section{E. Teori Kebijakan Hukum Pidana}

Istilah "kebijakan" diambil dari istilah "policy" (Inggris) atau "politiek" (Belanda). Menurut Marc Ancel, pengertian kebijakan hukum pidana (penal policy) adalah suatu ilmu sekaligus seni yang pada akhirnya mempunyai tujuan praktis untuk memungkinkan peraturan hukum positif dirumuskan secara lebih baik dan untuk memberi pedoman tidak hanya kepada pembuat undang-undang, tetapi juga kepada pengadilan yang menerapkan undang-undang dan juga kepada penyelenggara atau pelaksana putusan pengadilan. ${ }^{50}$

48 Baharuddin Lopa. 2001, Kejahatan Korupsi dan Penegakan Hukum. Buku Kompas. Jakarta. hal. 16-17.

49 Ibid.

50 Barda Nawawi Arief, 2011, Bunga Rampai Kebijakan Hukum Pidana, Jakarta: Prenada Media Group. hal. 23. 
Selanjutnya Barda Nawawi Arief menyatakan bahwa pada hakikatnya masalah kebijakan hukum pidana bukanlah semata-mata pekerjaan teknik perundang-undangan yang dapat dilakukan secara yuridis normative dan sistematik dogmatik. Disamping pendekatan yuridis faktual juga dapat berupa pendekatan komprehensif dari berbagai disiplin ilmu sosial lainnya dan pendekatan integral dengan kebijakan social dan pembangunan nasional pada umumnya. ${ }^{51}$

Barda Nawawi mengemukakan pola hubungan antar kebijakan hukum pidana (penal policy) dengan upaya penanggulangan kejahatan, beliau mengatakan bahwa pencegahan dan penanggulangan kejahatan harus dilakukan denga pendekatan integral dan ada keseimbanga antara penal dan non penal. Pencegahan dan pendekatan kejahatan dengan sarana penal merupaka penal policy atau Penal law Enforcement policy, yang fungsionalisasinya melalui beberapa tahap seperti tahap Formulasi (kebijakan legislatif), Aplikasi (kebijakan yudikatif) dan Eksekusi (kebijakan Administratif). ${ }^{52}$

Lebih lanjut Barda Nawawi Arief bahwa: Upaya atau kebijakan untuk melakukan pencegahan dan penanggulangan kejahatan termasuk bidang kebijakan kriminal. Kebijakan kriminal ini pun tidak terlepas dari kebijakan yang lebih luas, yaitu kebijakan sosial yang terdiri dari kebijakan/upaya-upaya untuk kesejahteraan sosial dan kebijakan/upaya-upaya untuk perlindungan masyarakat. Sehingga kebijakan penanggulangan kejahatan dilakukan dengan menggunakan sarana "penal" (hukum pidana), maka kebijakan hukum pidana khususnya pada tahap kebijakan yudikatif harus memperhatikan dan mengarah pada tercapainya tujuan dari kebijakan social itu berupa "social welfare" dan "social defence". ${ }^{53}$

Upaya atau kebijakan pencegahan dan penanggulangan kejahatan termasuk bidang kebijakan criminal (criminal policy).

51 Ibid. hal 24.

52 Ibid.

53 Arief, Barda Nawawi. 2007, Masalah Penegakan Hukum dan Kebijakan Hukum Pidana dalam Penanggulangan Kejahatan. Jakarta : Kencana Prenada Media Group. hal. 77. 
Kebijakan criminal tidak terlepas dari kebijakan yang lebih luas, yaitu kebijakan social (social policy) yang terdiri dari kebijakan untuk kesejahteraan sosial (social welfare policy) dan kebijakan untuk perlindungan masyakarat (social defence policy). Apabila penanggulangan kejahatan (politik criminal) dilakukan dengan menggunakan sarana penal (hukum pidana) maka kebijakan hukum pidana (penal policy) khususnya pada tahap kebijakan yudikatif harus memperhatikan dan mengarah pada tercapainya tujuan dari kebjikana social itu berupa social wlfare dan social defence. ${ }^{54}$

Dapat dijelaskan hal-hal pokok :55

1. Pencegahakan dan penanggulangan kejahatan harus menunjang tujuan (goal) kesejahteran masyarakat dan perlindungan masyarakat

2. Pencegahan dan penanggulangan kejahatan harus dilakukan dengan pendekatan integral ada keseimbangan sarana penal dan non penal.

3. Dari sudut politik criminal kebijakan paling strategis melalui sarana non penal karena lebih bersifat preventif dan karena kebijakan penal mempunyai keterbatasan atau kelemahan antara lain :

a. Bersifat fragmentaris, tidak structural funsional

b. Simptotik, tidak eliminative

c. Individualistic atau offender oriented, tidak victimoriented

d. Harus didukung infrastructure dengan biaya tinggi.

4. Dalam melakukan sarana penal, terdapat beberapa tahap yang harus dilalui yaitu:
a. Tahap formulasi kebijakan,
b. Tahap aplikasi
c. Tahap eksekusi 
Dalam tahap formulasi, upaya pencegahan dan penanggulangan kejahatan bukan hanya tugas aparat penegak hukum, tetapi juga pembuat hukum dalam hal ini legislative. Kebijakan legislative merupakan tahap paling strategis dari penal policy. Jika terjadi kesalahan atau kelemahan dalam perumusan perundangang-undangan akan berdampak pada terhambatnya upaya pencegahan dan penanggulangan kejahatan pada tahap berikutnya.

Strategi dasar penanggulangan kejahatan diarahkan pada upaya meniadakan (eliminasi) atau menanggulangi dan memperbaiki keseluruhan kuasa dan kondisi yang menjadi faktor kriminogen untuk terjadinya kejahatan. Jadi diperlukan pendekatan integral dalam arti :

1. Tidak hanya strategi penanggulangan simptotik dan represif lewat pembaruan dan penegakan hukum tetapi juga penanggulangan kausatif dan preventif

2. Tidak hanya melakukan law reform tetapi juga social economic, political, cultural, moral and administrative reform

3. Tidak hanya melakukan pembaharuan satu perundangundangan, tetapi juga semua perundang-undangan yang member peluang untuk terjadinya kejahatan. ${ }^{56}$

Tujuan dari kebijakan menetapkan suatu sanski pidana tidak dapat dilepaskan dari tujuan politik criminal dalam arti keseluruhannnya yaitu perlindungan masyarakat untuk mencapai kesejahteraan. Hal itu sejalan dengan kesimpulan seminar Kriminologi ke- 3 tahun 1976 yang merumuskan sebagai berikut :

Hukum Pidana hendaknya dipertahankan sebagai salah satu sarana untuk social defence dalam arti melindungi masyarakat terhadap kejahatan dengan memperbaiki atau memulihkan kembali (rehabilitasi) si pembuat tanpa mengurangi keseimbangan kepentingan perorangan (pembuat) dan masyarakat. ${ }^{57}$ Suatu kebijakan kriminal harus dapat

56 Ibid.

57 Muladi, 2010, Teori-teori dan Kebijakan Pidana, hal. 91-92. 
mengintegrasikan dan mengharmonisasikan seluruh kegiatan preventif yang non-penal itu ke dalam suatu sistem kegiatan negara yang teratur dan terpadu. Sehubugan dengan itu, Radzinoowics sebagaimana dikutip dalam Muladi menyatakan bahwa: ${ }^{58}$ Criminal policy must combine the various preventive activities and adjust them so as to form a single comprehensive machine and finally coordinate the whole into an organized system of activity. Kebijakan krimimal yang integral diharapkan mencapai social defence.

Prof. Sudarto, SH pernah mengemukakan tiga arti mengenai kebijakan kriminal, yaitu : a). dalam arti sempit, ialah keseluruhan asas dan metode yang menjadi dasar dari reaksi terhadap pelanggaran hukum yang berupa pidana; b). dalam arti luas, ialah keseluruhan fungsi dari aparatur penegak hukum, termasuk di dalamnya cara kerja dari pengadilan dan polisi; c). dalam arti paling luas (yang beliau ambil dari Jorgen Jepsen), ialah keseluruhan kebijakan, yang dilakukan melalui perundang-undangan dan badan-badan resmi, yang bertujuan untuk menegakkan norma-norma sentral dari masyarakat. Prof. Sudarto mengemukakan bahwa kebijakan kriminal harus dilakukan pula dengan pendekatan yang berorientasi pada kebijakan sosial dengan memperhatikan hal-hal yang pada intinya sebagai berikut :59

1. Penggunaan hukum pidana harus memperhatikan tujuan pembangunan nasional yaitu mewujudkan masyarakat adil makmur yang merata materiil dan spirituil berdasarkan Pancasila; sehubungan dengan ini maka (penggunaan) hukum pidana bertujuan untuk menanggulangi kejahatan dan mengadakan pengugeran terhadap tindakan penanggulangan itu sendiri, demi kesejahteraan dan pengayoman masyarakat.

2. Perbuatan yang diusahakan untuk dicegah atau ditanggulangi dengan hukum pidana harus merupakan "perbuatan yang tidak dikehendaki" yaitu perbuatan yang

58 Ibid, hal. 159.

59 Sudarto, 1986, Hukum dan Hukum Pidana, Op.Cit., hal. 36-39. 
mendatangkan kerugian (materiil dan atau spirituil) atas warga masyarakat.

3. Penggunaan hukum pidana harus pula memperhitungkan prinsip biaya dan hasil (cost and benefit principle)

4. Penggunaan hukum pidana harus pula memperhatikan kapasitas atau kemampuan daya kerja dari badan-badan penegak hukum, yaitu jangan sampai ada kelampauan beban tugas (overbelasting). 


\section{BAB III \\ KONSEPSI TINDAK \\ PIDANA KORUPSI}

\section{A. Konsepsi Korupsi Secara Umum}

Pengertian korupsi menurut John A. Gardiner dan David

J. Olson sebagaimana yang dikutip oleh Martiman Prodjohamidjojo antara lain $:{ }^{60}$

1. Rumusan Korupsi dari sisi pandang teori pasar

Jacob Van Klaveren mengatakan bahwa seorang pengabdi negara (pegawai negeri) yang berjiwa korup menganggap kantor/instansinya sebagai perusahaan dagang, sehingga dalam pekerjaannya diusahakan pendapatannya akan diusahakan semaksimal mungkin.

2. Rumusan yang menekankan titik berat jabatan pemerintahan

M. Mc. Mullan mengatakan bahwa seorang pejabat pemerintahan dikatakan korup apabila menerima uang yang dirasakan sebagai dorongan untuk melakukan sesuatu yang bisa dilakukan dalam tugas dan jabatannya padahal seharusnya tidak boleh melakukan hal demikian selama menjalankan tugas. J.S. Nye berpendapat bahwa korupsi sebagai prilaku yang menyimpang dari kewajiban- kewajiban normal suatu peran instansi pemerintah, karena kepentingan pribadi (keluarga, golongan, kawan, teman), demi mengejar status dan gensi, atau melanggar peraturan dengan jalan melakukan atau mencari pengaruh bagi kepentingan pribadi.

3. Rumusan korupsi dengan titik berat pada kepentingan umum.

Carl J. Friesrich, mengatakan bahwa pola korupsi dikatakan ada apabila seorang memegang kekuasaan yang berwenang untuk melakukan hal-hal tertentu seperti seorang pejabat

60 Martiman Prodjohamidjojo, 2001, Penerapan Pembuktian Terbalik dalam Delik Korupsi (UU No. 20 Tahun 2001), CV. Mandar Maju, Jakrta, hal. 8-14 
yang bertanggung jawab melalui uang atau semacam hadiah lainnya yang tidak dibolehkan oleh undangundang; membujuk untuk mengambil langkah yang menolong siapa saja yang menyediakan hadiah dan dengan demikian benar- benar membahayakan kepentingan umum.

4. Rumusan korupsi dari sisi pandangan sosiologi

Makna korupsi secara sosiologis dikaji oleh Martiman Prodjohamiodjojo dengan mengemukakan pendapat Syeh Hussein Alatas yang mengatakan bahwa: "Terjadi korupsi adalah apabila seorang pengawai negeri menerima pemberian yang disororkan oleh seorang dengan maksud mempengaruhinya agar memberikan perhatian istimewa pada kepentingan-kepentingan sipemberi. Kadang-kadang juga berupa perbuatan menawarkan pemberian uang hadiah lain yang dapat menggoda pejabat. Termasuk dalam pengertian ini juga pemerasan yakni permintaan pemberian atau hadiah seperti itu dalam pelaksanaan tugas-tugas publik yang mereka urus bagi keuntungan mereka sendiri. ${ }^{61}$ Sementara H. A. Brasz mendefinisikan korupsi dalam pengertian sosiologis sebagai: "Penggunaan yang korup dari kekuasaan yang dialihkan, atau sebagai penggunaan secara diam-diam kekuasaan yang dialihkan berdasarkan wewenang yang melekat pada kekuasaan itu atau berdasarkan kemampuan formal, dengan merugikan tujuan- tujuan kekuasaan asli dan dengan menguntungkan orang luar atas dalih menggunakan kekuasaan itu dengan sah". ${ }^{62}$ Tampaknya H. A. Brasz dalam mendefinisikan korupsi sangat dipengaruhi oleh definisi kekuasaannya Van Doorn. ${ }^{63}$ Dari berbagai definisi korupsi yang dikemukakan,menurut Brasz terdapat dua unsur di dalamnya, yaitu penyalahgunaan kekuasaan yang melampaui batas kewajaran hukum oleh para pejabat atau aparatur negara; dan pengutamaan kepentingan pribadi

61 Ibid., hal. 11

62 Mochtar Lubis dan James C. Scott, 1995, Bunga Rampai Korupsi, Cet. ke3 (Jakarta: LP3ES), hal. 4.

63 Ibid., hal. 3. 
atau klien di atas kepentingan publik oleh para pejabat atau aparatur negara yang bersangkutan.

\section{B. Konsepsi Tindak Pidana Korupsi Secara Etimologis}

Pengertian tindak pidana korupsi dapat diartikan dalam dua kata yang terpisah, yaitu kata "tindak pidana" dan akata "korupsi". Pengertian kedua kata tersebut dapat kita lihat sebagai berikut: 64

1. Istilah "tindak pidana" merupakan istilah teknis juridis yang berasal dari bahasa Belanda yaitu "strafbaar feit" atau "delict" dimana kata ini berarti perbuatan yang diarang oleh peraturan hukum pidana dan dapat dikenakan sanksi pidana bagi siapa saja yang melanggarnya.

2. Istilah "Korupsi" berasal dari bahasa latin yaitu Corruptie atau corruptus. Selain itu kata korupsi juga berasal dari kata Corrumpere suatu kata yang lebih tua dan akhirnya diturunkan dalam bahasa Inggris yaitu Corruption, dalam bahasa Prancis Corruption dan bahasa Belanda Coruptie.

Sedangkan dalam kamus Bahasa Indonesia dikatakan Korupsi adalah perbuatan berupa menerima suap, memanfaatkan jabatan untuk mengeruk keuntungan secara tidak sah. ${ }^{65}$ Yang mana Definisi korupsi (bahasa Latin: corruptio dari kata kerja corrumpere artinya busuk, rusak, menggoyahkan, memutarbalik, menyogok) menurut Transparency International adalah perilaku pejabat publik, baik politikus|politisi maupun pegawai negeri, yang secara tidak wajar dan tidak legal memperkaya diri atau memperkaya mereka yang dekat dengannya, dengan menyalahgunakan kekuasaan publik yang dipercayakan kepada mereka.

Dari sudut pandang hukum, tindak pidana korupsi secara garis besar mencakup unsur-unsur sebagai berikut:

64 Andi Hamzah, 1991, Korupsi di Indonesia, Masalah dan Pemecahannya, PT. Gramedia Pustaka Utama, Jakarta. hal. 9. hal. 36 .

65 Daryanto, 1997, Kamus Lengkap Bahasa Indonesia, Apollo, Surabaya, 
1. Perbuatan melawan hukum;

2. Penyalahgunaan kewenangan, kesempatan, atau sarana;

3. Memperkaya diri sendiri, orang lain, atau korporasi;

4. Merugikan keuangan negara atau perekonomian negara;

Selain itu terdapat beberapa jenis tindak pidana korupsi yang lain, diantaranya:

1. memberi atau menerima hadiah atau janji (penyuapan);

2. penggelapan dalam jabatan;

3. pemerasan dalam jabatan;

4. ikut serta dalam pengadaan (bagi pegawai negeri/penyelenggara negara);

5. menerima gratifikasi (bagi pegawai negeri/penyelenggara negara).

Olehnya itu, menurut wujudnya atau sifatnya, perbuatan-perbuatan pidana adalah perbuatan-perbuatan yang melawan hukum khususnya korupsi merupakan perbuatan yang merugikan ekonomi dan keuangan negara, menguntungkan diri sendiri, orang lain atau corporation dalam arti merupakan perbuatan buruk dan menyimpang bertentangan dengan atau menghambat akan terlaksananya tata dalam pergaulan masyarakat yang dianggap baik dan adil. 66

Dari pengertian tin korupsi secara etimologi diatas dapat dipahami bahwa pada dasarnya korupsi merupakan suatu kegiatan yang bertentangan dengan ketentuan perundang- undangan, dimana perbuatan tersebut dilakukan untuk memperkaya diri pribadi secara tidak sah.

\section{Konsepsi Tindak Pidana Korupsi dalam Pandangan Ahli}

Menurut Moeljatno tindak pidana adalah Perbuatan yang dilarang oleh suatu aturan hukum larangan dengan mana 
disertai ancaman (sanksi) yang berupa pidana tertentu, bagi barang siapa yang melanggar larangan tersebut.

Pengertian straafbaarfeit menurut Simons dalam rumusannya adalah Tindakan yang melanggar hukum yang telah dilakukan dengan sengaja ataupun tidak dengan sengaja oleh seseorang yang dapat dipertanggungjawabkan atas tindakannya dan oleh Undang-Undang telah dinyatakan sebagai tindakan yang dapat dihukum. Rumusan pengertian tindak pidana (straafbaarfeit) yang dinyatakan oleh Simons juga diatur dalam asas hukum pidana Indonesia, yaitu asas legalitas (principle of legality) atau dalam bahasa latin biasanya dikenal dengan "Nullum Delictum Noella Poena Sine Praevia Lege Poenali", maksudnya bahwa "Tidak ada perbuatan yang dilarang dan diancam dengan pidana jika tidak ditentukan terlebih dahulu dalam perundangundangan". Tindak pidana akan melahirkan pertanggungjawaban pidana yang hanya dapat terjadi setelah sebelumnya seseorang melakukan tindak pidana, dimana pertanggungjawaban pidana dilakukan dengan asas yang berbeda yaitu dengan asas yang tidak tertulis "Tiada pidana tanpa kesalahan" 67. Tindak pidana merupakan suatu pengertian dasar dalam Hukum Pidana.

Tindak Pidana adalah pengertian yuridis, lain halnya dengan istilah perbuatan jahat atau kejahatan ( crime atau verbrechen atau misdaad) yang biasa diartikan seeara yuridis (hukum) atau secara kriminologis. Barda Nawawi Arief menyatakan" tindak pidana secara umum dapat diartikan sebagai perbuatan yang melawan hukum baik secara formal maupun secara materiil"

Menurut Wirjono Projodikoro, "Bahwa pengertian tindak pidana adalah suatu perbuatan yang pelakunya dapat dikenakan pidana, sedangkan menurut Moeljatno, perbuatan pidana adalah suatu perbuatan yang pelakunya dapat dikenakan pidana, bagi yang melanggar perbuatan tersebut.

67 Chairul Huda, 2006, Dari Tiada Pidana Tanpa Kesalahan Menuju Kepada Tiada Pertanggungjawaban Pidana Tanpa Kesalahan, Kencana Prenada Media, Jakarta, hal. 20. 
Jadi perbuatan yang dapat dikenakan pidana dibagi menjadi 2 (dua): 68

1. Perbuatan yang dilarang oleh undang-undang.

2. Orang yang melanggar larangan itu.

Selain pengertian korupsi dapat juga dijelaskan dalam pandangan beberapa ahli hukum. Yang dapat dijelaskan sebagai mana berikut : 69

1. Soejono Dirdjosisworo: menurutnya korupsi dapat diartikan dalam beberapa pengertian sebagai berikut :

a. Perbuatan yang dalam kenyataan menimbulkan

keadaan yang bersifat buruk.

b. Perilaku yang jahat dan tercela, atau kebejadan moral.

c. Sesuatu yang dikorup

d. Pengaruh-pengaruh yang korup.

2. Djoko Prakoso dan Ali Suryati : Menurutnya korupsi berarti kemerosotan dari keadaan yang semua baik, sehat, benar, menjadi penyelewengan, busuk, kemerosotan itu terletak pada fakta bahwa orang yang menggunakan kekuasaan, kewibawaan dan wewenang jabatan, menyimpang dari tujuan semula yang dimaksud. Dalam bukunya tersebut Djoko Prakoso dan Ali Suryati juga memasukkan upeti sebagai salah satu bentuk korupsi. ${ }^{70}$

3. Syed Hussein Alatas : Korupsi ada apabila seorang pejabat menerima pemberian yang disodorkan oleh seseorang swasta dengan maksud mempengaruhinya agar memberikan perhatian istimewa pada kepentingankepentingan si pemberi, terhadap perbuatan menarik perhatianseperti itu atau hal lain yang menggoda juga mencakup konsep itu. ${ }^{71}$

68 Sudarto, 1990, Hukum Pidana I, Semarang : Yayasan Sudarto, hal. 38. 69 Soedjono Dordjosisworo, 1986, Fungsi Perundang-undangan Pidana Dalam Penanggulangan Korupsi di Indonesia, Sinar Baru, Bandung. Hal. 17. 70 Djoko Prakoso dan Ati Suryati, 1986, Upetisme Ditinjau Dari Undangundang Pemberantasan Tindak Pidana Korupsi, Bumi Aksara, Jakarta. hal. 8.

71 Riduan Syahrani, 1983, Beberapa hal Tentang Hukum Acara Pidana, Alumni, Bandung, hal. 87. 
4. J.S.Nye : menjelaskan bahwa korupsi adalah sebagai perilaku menyimpang dari kewajiban-kewajiban normal suatu perusahaan jawatan pemerintah karena kepentingan pribadi (keluarga, golongan, dan kawan akrab) dalam melakukan atau mencari pengaruh bagi kepentingan pribadi, hal tersebut meliputi tindakan sebagai penyuapan, pemberian hadiah dengan maksud menyelewengkan pertimbangan seseorang dalam kedudukan pada jabatan dinasnya. ${ }^{72}$

Secara substansial oleh Andi Hamzah menggunakan Istilah korupsi dalan konsep perbuatan melawan hukum (wederrechtelijk) dikenal dalam ilmu hukum pidana yang diartikan perbuatan yang bertentangan dengan hukum objektif, hukum subjektif, dan tidak mempunyai hak sendiri (Andi Hamzah, terminologi hukum pidana, 2009:26). Pengertian ini mengisyaratkan bahwa unsur perbuatan melawan hukum bermakna lebih luas dibandingkan dengan istilah perbuatan pidana (strafbaarfeit) karena disamping melanggar aturan perundang-undangan, juga harus bertentangan dengan hukum subjektif (kepatutan, kelaziman, dan norma-norma adat dalam kehidupan masyarakat) dan hak orang lain. Untuk itu terdapat perbuatan melawan hukum dibedakan atas dua jenis yaitu perbuatan melawan hukum formil (formele wederrechtelijkheid) dan perbuatan melawan hukum materiil (materiele wederrechtelijkheid). Penerapan konsep perbuatan melawan hukum materiil tidak efektif dan kurang mendapat perhatian dalam sistem peradilan pidana di Indonesi.

Persoalan sifat melawan hukum menjadi perdebatan para ahli hukum pidana terkait sifat melawan hukum formil atau disebut on wet dan sifat melawan hukum materiil atau disebut on recht. Pelanggaran terhadap pasal yang diatur dalam KUHP dianggap melawan hukum secara formil meskipun anasir deliknya tidak disebut dalam pasal. Oleh C.S.T.Kansil, Jika dijadikan sebagai anasir delik, maka ia tidak hanya 
melawan hak secara formil, melainkan juga secara materiil, jadi unsur melawan hukum yang disebut dalam pasal yang bersangkutan harus dibuktikan melawan hukum formil dan materiilnya. Perbuatan melawan hukum dalam tindak pidana korupsi juga mencakup perbuatan melawan hukum dalam arti formil maupun dalam arti materiil, yakni meskipun perbuatan tersebut tidak diatur dalam peraturan perundang-undangan, namun apabila perbuatan tersebut dianggap tercela karena tidak sesuai dengan rasa keadilan atau norma-norma kehidupan sosial dalam masyarakat, maka perbuatan tersebut dapat dipidana.

Dengan demikian maka dapat disimpulkan bahwa korupsi adalah tindakan yang dilakukan oleh setiap orang yang secara melawan hukum melakukan perbuatan memperkaya diri sendiri atau orang lain atau suatu korporasi yang dapat merugikan negara atau perekonomian Negara. atau tindakan yang dilakukan oleh setiap orang yang kewenangan, kesempatan atau sarana yang ada padanya karena jabatan atau kedudukan yang dapat diartikan tindakan yang tidak menyetujui terhadap berbagai upaya yang dilakukan oleh setiap orang yang dengan tujuan menguntungkan diri sendiri atau orang lain atau suatu korporasi, menyalahgunakan kewenangan, kesempatan atau sarana yang ada padanya karena jabatan atau kedudukan yang dapat merugikan keuangan negara atau perekonomian negara dan diancam dengan pidana.

\section{Konsepsi Tindak Pidana Korupsi dalam Undang-Undang di Indonesia}

Secara histori Istilah korupsi pertama sekali hadir dalam khasanah hukum Indonesia dalam Undang-Undang RI Nomor

79 Tahun 1957 tentang Keadaan Bahaya, serta peraturan Penguasa Perang Nomor Prt/Perpu/013/1958 tentang Peraturan Pemberantasan Korupsi. Kemudian dimasukan juga dalam Undang-Undang RI Nomor 24/Prp/1960 tentang Pengusutan Penuntutan dan Pemeriksaan Tindak Pidana Korupsi dan Keputusan Presiden Nomor 228 Tahun 
1967 
tentang Tindak Pidana Korupsi. Undang-undang ini kemudian dicabut dan digantikan oleh Undang-Undang RI Nomor 3 Tahun 1971 Tentang Pemberantasan Tindak Pidana Korupsi, yang kemudian sejak tanggal 16 Agustus 1999 digantikan oleh Undang-undang Nomor 31 Tahun 1999 Tentang Tindak Pidana Korupsi dan akan mulai berlaku efektif paling lambat 2 tahun kemudian (16 Agustus 2001) dan kemudian dirubah dengan Undang-undang Nomor 20 Tahun 2001 tentang Perubahan atas Undang-Undang RI Nomor 31 Tahun 1999 tentang Tindak Pidana korupsi (tanggal 21 November 2001).

\section{Undang-Undang RI Nomor 79 Tahun 1957 tentang Keadaan} Bahaya:

Dalam undang-undang Nomor 79 Tahun 1957 tentang keadaan bahaya, kata "korupsi" tidak didefinisikan secara tegas namun pengertiannya digabungkan dengan perbuatan korupsi yang mana dapat dilihat dalam pasal 1 bagian 1 dan dijabarkan dalam pasal 2 dan pasal 3. Perbuatan korupsi diklasifikasikan menjadi dua yaitu perbuatan korupsi pidana dan perbuatan korupsi lainnya.

a. Perbuatan korupsi

Perbautan korupsi di dalam Pasal 1 Undang-undang Nomor 79 tahun 1957 dapat diklasifikasikan sebagai berikut :

1) Perbuatan seseorang yang dengan atau karena melakukan sesuatu kejahatan atau pelanggaran memperkaya diri sendiri atau orang lain atau suatau badan yang secara langsung atau tidak langsung merugikan suatau badan keuangan Negara atau daerah atau badan hukum lain, yang menggunakan modal atau kelonggaran-kelonggaran dari masyarakat.

2) Perbuatan seseorang yang dengan atau karena melakukan sesuatu kejahatan atau pelanggaran memperkaya diri sendiri atau orang lain atau suatau badan, serta yang dilakukan dengan menyalahgunakan suatu jabatan ataukedudukan. 
3) Kejahatan-kejahatan yang tercantum dalam pasal 209,210, 418, 419, dan 420 Kitab Undang-undang Hukum Pidana (KUHP).

b. Perbuatan korupsi lainnya

Perbuatan korupsi lainnya dapat dijelaskan dalam Pasal 2 Undang-Undang Nomor 79 Tahun 1957 berikut ini :

1) Perbuatan seseorang yang dengan atau karena melakukan sesuatu perbuatan melawan hukum memperkaya diri sendiri atau orang lain atau susuatu badan yang secara langsung atau tidak langsung merugikan keuangan Negara atau merugikan keuangan suatau badan yang menerima bantuan dari keuangan Negara atau daerah, atau bdan lain, yang menggunakan modal dan kelonggaran-kelonggaran dari masyarakat.

2) Perbuatan seseorang yang deangan atau karena meakukan sesuatu perbuatan melawan hukum memperkaya diri sendiri atau orang lain atau sesuatu badan yang dilakuakn dengan menyalahgunakan jabatan atau kedudukan.

2. Undang-Undang RI Nomor 24 Tahun 1960 Tentang Pengusutan, Penuntutan dan Pemeriksaan Tindak Pidana Korupsi

Pengertian Korupsi di dalam Undang-Undang Nomor 24 Tahun 1960 tertuang pada pasal 1 sebagai berikut :

a. Tindakan seseorang yang dangan atau karena melakukan sesuatu kejahatan atau pelanggaran memeperkaya diri sendiri atau orang lain atau sesuatu badan yang secara langsung atau tidak langsung merugikan keuangan Negara atau perekonomian dari keuangan Negara atau daerah atau badan hukum lain, yang mempergunakan modal dan kelonggarankelonggaran dari segara atau masyarakat.

b. Tindakan seseorang yang dengan atau karna melakukan sesuatu kejahatan atau pelanggaran memperkaya diri 
sendiri atau orang lain atau badan dan yang dilakukan dengan menyalahgunakan jabatan atau kedudukan.

c. Kejahatan-kejahatan yang tercantum dalam pasal 17 sampai dengan Pasal 21 peraturan ini dan dalam pasal 209,210, 415, 416, 417, 418, 419, 420, 423, 425, dan 435 Kitab Undang-undang Hukum Pidana (KUHP)

\section{Undang-Undang RI Nomor 3 tahun 1971 tentang Pemberantasan Tindak Pidana Korupsi}

Dalam undang-undang nomor 3 tahun 1971 ada dua sumber perumusan delik, yaitu bersumberkan pasal-pasal KUHP yang ditarik sebanyak 13 (tiga belas) pasal ditambah dengan 6 (enam) pasal yang dinaikkan pidananya dan perumusan dari Undang-undang ini sendiri sebanyak 7 (tujuh) perumusan delik dalam 4 (empat) pasal. Kedua ini tidak ditarik secara mutlak, seperti yang tersebut pada yang pertama. Pasal 1:

a. Di hukum karena tindak pidana korupsi ialah :

1) Barang siapa dengan melawan hukum melakukan perbuatan memperkaya diri sendiri atau orang lain, atau suatu badan, yang secara langsung atau tidak langsung merugikan keuangan Negara dan atau perekonomian Negara atau diketahui atau patut disangka olehnya bahwa perbuatan tersebut merugikan keuangan Negara atau perekonomian Negara.

2) Barang siapa dengan tujuan menguntungkan diri sendiri atau orang lain atau suatu badan menyalahgunakan kewenangan, kesempatan atau sarana yang ada padanya karena jabatan atau kedudukan yang secara langsung atau tidak langsung dapat merugikan keuangan Negara atau perekonomian Negara.

3) Barang siapa melakakukan kejahatan tercantum dalam pasal 219, 210, 387, 288,415, 416, 217, 418, 419, 420, 423, 435 KHP. 
4) Barang siapa memberi hadian atau janji kepada pegawai negeri seperti termasuk dalam pasal 2 mengingat sesuatu kekuasaan atau suatu wewenang yang melekat padanya atau kedudukannya atau oleh pemberi hadiah atau janji dianggap melekat pada jabatan atau kedudukan itu.

5) barang siapa tanpa alasan yang wajar dalam waktu yang sesingkat-singkatnya setelah menerima pemberian atau janji yang diberikan padanya seperti tersebut dalam pasal-pasal 418, 419, daan 420 KUHP tidak melaporkan pemberian atau janji tersebut kepada yang berwajib.

b. Barang siapa melakukan percobaan atau pemufakatan untuk melakukan tindak pidana-tindak pidana tersebut dalam ayat (1) a,b,c,d, dan e pasal ini.

Pasal 2 : "Pegawai negeri yang dimaksud oleh undangundang ini, meliputi juga orang-orang yang menerima gaji atau upah dari keuangan Negara atau daerah atau yang menerima gaji atau upah dari suatu badan/badan hukum yang menerima bantuan dari keuangan Negara atau daerah atau badan hukum lain yang mempergunakan modal dan kelonggaran-kelonggaran dari Negara atau masyarakat."

4. Undang-Undang RI Nomor 28 Tahun 1999 tentang Penyelenggaraan Negara Yang Bersih dan Bebas Korupsi, Kolusi dan Nepotisme.

Undang-Undang No. 28 Tahun 1999 tentang Penyelenggaraan Negara Yang Bersih dan Bebas Korupsi, Kolusi dan Nepotisme Pasal 1 ayat 3,4,5 dengan penjabaran

a. Korupsi adalah tindak pidana sebagaimana dimaksud dalam ketentuan peraturan perundang - undangan yang mengatur tindak pidana korupsi.

b. Kolusi adalah pemufakatan atau kerjasama secara melawan hukum atau penyelenggara negara atau antara 
penyelenggara negara dan pihak lain yang merugikan orang lain, masyarakat dan atau negara.

c. Nepotisme adalah setiap perbuatan penyelenggara negara secara melawan hukum yang menguntungkan kepentingan keluarganya dan atau kronnya diatas kepentingan masyarakat, bangsa dan negara.

\section{Undang-Undang RI Nomor 31 tahun 1999 tentang Pemberantasan Tindak pidana Korupsi}

Dalam undang-undang Nomor 31 Tahun 1999 ini dikenal ada 4 (empat) tipe tindak pidana korupsi. Untuk itu, maka penulis membahas pengertian korupsi berdasarkan masing- masing tipe tersebut, yaitu :

a. Pengertian korupsi tipe pertama

Pengertian korupsi ini tercantum dalam pasal 2 Undang-undang Nomor 31 Tahun 1999 yang menyebutkan bahwa " Setiap orang yang secara melawan hukum melakukan perbuatan yang memperkaya diri sendiri atau orang lain atau koorporasi yang dapat merugikan keuangan Negara atau perekonomian Negara, di pidana dengan pidana penjara seumur hisup atau penjara paling singkat 4 (empat) tahun atau yang paling lama 20 (dua puluh) tahun dan denda paling sedikit Rp 200.000.000,00 (dua ratus juta rupiah) dan paling banyak Rp. 1.000.000.000,00 (satu milyar rupiah).

Dari bunyi pasal 2 ini dapat ditarik unsureunsurnya yaitu :

1) Kegiatan memperkaya diri sendiri atau orang lain atau suatu koorporasi: Pengertian memperkaya diri sendiri dapat ditafsirkan suatu perbuatan dengan mana sipelaku bertambah kekayaannya oleh karena perbuatan tersebut.

2) Dapat merugikan keuangan atau perekonomian Negara: Pengertian merugikan keuangan atau perekonomian Negara menurut pembentuk undangundang dalam penjelasannya menentukan bahwa 
keuangan Negara adalah seluruh kekayaan Negara dalam bentuk apapun, yang dipisahkan atau yang tidak dipisahkan, termasuk di dalamnya segala bagian kekayaan Negara dan segala hak dan kewajiban yang timbul karena :

a) Berada dalam penguasaan, pengurusan, dan pertanggungjawaban pejabat negara, baik ditingkat pusat maupun daerah.

b) Berada dalam pengurusan dan pertanggung jawaban Badan Usaha Milik Negara/badan Usaha Milik daerah, Yayasan, badan Hukum, dan perusahaan yang menyertakan modal Negara, atau perusahaan yang menyertakan modal pihak ketiga berdasarkan perjanjian dengan Negara.

3) Dalam hal tertentu pelaku tindak pidana korupsi dapat dijatuhi pidana mati. Yang dimaksud dengan keaadaan tertentu adalah sebagai pemberatan bagi pelaku tindak pidana korupsi apabila tindak pidana tersebut dilakukan pada waktu Negara dalam keadaan bahaya sesuai dengan ndang-undang yang berlaku, pada waktu terjadi bencana alam nasional, atau pada waktu terjadi krisis ekonomi dan moneter.

b. Pengertian korupsi tipe kedua

Pengertian korupsi yang kedua ini tercantum dalam pasal 3 Undang-undang Nomor 31 Tahun 1999, yang berbunyi sebagai berikut :

"Setiap orang yang dengan tujuan menguntungkan diri sendiri atau orang lain atau koorporasi, menyalahgunakan kewenangan, kesempatan atau sarana yang ada padanya karena jabatan atau kedudukan yang dapat merugikan keuangan Negara atau perekonomian Negara, dipidana dengan pidana penajara seumur hidup atau pidana penajara paling singkat 1 (satu) tahun dan atau denda paling sedikit 
Rp. 50.000.000,00 (lima puluh juta rupiah) atau paling banyak Rp 1.000.000,00 (satu milyar rupiah)"

Dari bunyi pasal ini dapat ditarik unsur-unsurnya yaitu ;

1) Menyalahgunakan kewenangan, kesempatan atau sarana yang ada padanya karena jabatan atau kedudukan. Pada hakekatnya pengertian korupsi tipe kedua ini hanya dapat dikenakan terhadap para pegawai negeri karena hanya merekalah yang memiliki sarana dan kesempatan untuk perbuatan korupsi tipe kedua ini.

2) Perbuatan tersebut dapat mergikan keungan Negara atau perekonomian Negara. Dalam unsure ini terselip kata "dapat" yang berarti bahwa Jaksa/Penuntut umum tidaklah harus membuktikan adanya unsure kerugian Negara karena tindak pidana korupsi merupakan delik formal, yaitu adanya tindak pidana korupsi cukup dengan dipenuhinya unsure-unsur perbuatan yang sudah dirumuskan, bukan dengan timbulnya akibat.

c. Pengertian korupsi tipe ketiga

Pasa azasnya, pengertian korupsi tipe ketiga ini terdapatdalam ketentuan pasal 5,6,7,8,9,11, 12, 13, Undang-undang nomor 31 tahun 1999 yang berasal dari KUHP. Pengertian korupsi tipe ketiga ini dapat digolongkan lagi ke dalam 4 (empat) pengelompokan, yaitu :

1) Penarikan perbuatan yang berupa penyuapanyakni pasal 209, pasal 210, pasal 418, pasal 419 dan pasal 420 KUHP.

2) Penarikan perbuatan yang bersifat penggelapan, yakni pasal 415, 416, dan pasal 417 KUHP.

3) Penarikan perbuatan yang bersifat kerasukan yakni pasal 423 dan pasal 425 KUHP. 
4) Penarikan perbuatan yang berkolerasi dengan pemborongan, leveransir dan rekanan yakni pasal 387,388, dan pasal 435 KUHP.

d. Pengertian korupsi tipe keempat

Pada dasarnya pengertian korupsi tipe keempat adalah tipe korupsi percobaan, pembantuan dan permufakatan jahat serta pemberian kesempatan, sarana atau keterangan sehingga terjadinya tindak pidana korupsi.Perbuatan korupsi merupakan perbuatan yang sangat merugikan keuangan dan perekonomian Negara sehingga untuk itu maka percobaan melakukan tindak pidana korupsi ini juga merupakan delik yang berdiri sendiri dan dianggap selesai.

e. Pengertian korupsi tipe kelima

Sebenarnya pengertian korupsi tipe kelima ini bukanlah bersifat murni tindak pidana korupsi, tetapi tindak pidana lain yang berkaitan dengan tindak pidana korupsi sebagaimana hal ini terdapat dalam Bab III pasal

21 sampai dengan pasal 24 ndang-undang Nomor 31 Tahun 1999, yang berbunyi sebagai berikut :

1) Setiap orang yang dengan sengaja mencegah, merintangi, atau menggagalkansecara langsung atau tidak langsung penyidikan, penuntutan, dan pemeriksaan disidang pengadilan terhadap tersangka, terdakwa ataupun para saksi dalam perkara korupsi di pidana dengan pidana penjara paling singkat 3 (tiga) tahun dan paling lama 12 (dua belas) tahun dan atau denda paling sedikit Rp 150.000.000,- (seratus lima puluh juta rupiah) dan paling banyak Rp 600.000.000,- (enam ratus juta rupiah).

2) Dalam perkara Korupsi, pelanggaran terhadap ketentuan sebagaimana dimaksud dalam 220, pasal 231, pasal 241, pasal 422, pasal 429, atau pasal 430 Kitab Undang-Undang Hukum Pidana (KUHP) 
dengan pidana paling sedikit 1 (satu) tahun dan paling lama 6 (enam) tahun dan atau denda paling sedikit Rp 50.000.000,00 (lima puluh juta rupiah) dan paling banyak $\mathrm{Rp} 300.000 .000,00$ (tiga ratus Juta Rupiah) dan, Sanksi yg tidak memenuhi ketentan sebagaimana di maksud dalam pasal 31 Undangundang Nomor 31 Tahun 1999, di pidana dengan pidana penjara paling lama 3 (tiga) tahun atau denda paling banyak Rp 150.000.000,00 (seratus lima puluh juta rupiah).

\section{Undang-Undang RI Nomor 20 Tahun 2001 tentang Pemberantasan Tindak Pidana Korupsi}

Dalam undang-undang nomor 20 Tahun 2001 tentang Pemberantasan Tindak Pidana Korupsi tidak ada menyebutkan defenisi atau pengertian korupsi. Undangundang Nomor 20 tahun 2011 hanya menyebutkan instansi atau orang pribadi yang dapat melakukan tindak pidana korupsi, yaitu :

a. Korupsi adalah sekumpulan orang atau kekayaan yang terorganisasi baik merupakan badan hukum maupun bukan badan hukum.

b. Pegawai Negeri adalah meliputi :

1) Pegawai negeri sebagaimana dimaksud dalam Undang-undang tentang kepegawaian.

2) Pegawai Negeri sebagaimana dimaksud dalam Kitab Undang-Undang Hukum pidana.

3) Orang yang menerima gaji atau upah dari keuangan Negara atau daerah.

4) Orang yang menerima gaji atau upah dari suatu korporasi yang menerima bantuan dari keluarga Negara atau daerah, atau

5) Orang yang menerima gaji atau upah dari korporasi lain yang mempergunakan modal dan fasilitas dari Negara atau masyarakat. 
c. Setiap orang adalah perseorangan atau termasuk korporasi: Selanjutnya Undang-undang Nomor 20 tahun 2001 memberikan ketentuan pidana kepada 3 subjek yang dapat melakukan korupsi diatas serta menekankan pentingnya peran serta masyarakat dalam kegiatan penanggulangan dan pemberantasan korupsi.

\section{E. Kedudukan Korupsi Sebagai Tindak Pidana Khusus}

Istilah Hukum Pidana Khusus, sekarang diganti dengan istilah Hukum Tindak Pidana Khusus. Timbul pertanyaan apakah ada perbedaan dari kedua istilah ini. Seacara prinsipil tidak ada perbedaan antara kedua istilah ini. Oleh karena yang dimaksud dengan kedua istilah itu adalah UndangUndang Pidana yang berada di luar Hukum Pidana Umum yang mempunyai penyimpangan dari Hukum Pidana Umum baik dari segi Hukum Pidana Materil maupun dari segi Hukum Pidana Formal. Kalau tidak ada penyimpangan tidaklah disebut hukum Pidana Khusus atau Hukum Tindak Pidana Khusus. Hukum tindak pidana khusus mengatur perbuatan tertentu atau berlaku terhadap orang tertentu yang tidak dapat dilakukan oleh orang lain selain orang tertentu. Oleh karena itu hukum tindak pidana khusus harus dilihat dari substansi dan berlaku kepada siapa Hukum Tindak Pidana Khusus itu. Hukum Tindak pidana khusus ini diatur dalam Undang- Undang di luar Hukum Pidana Umum. Penyimpangan ketentuan hukum pidana yang terdapat dalam Undang- Undang pidana merupakan indikator apakah Undang-Undang pidana itu merupakan Hukum Tindak Pidana Khusus atau bukan. Sehingga dapat dikatakan bahwa Hukum Tindak Pidana Khusus adalah Undang-Undang Pidana atau Hukum Pidana yang diatur dalam UndangUndang pidana tersendiri. Pernyataan ini sesuai dengan pendapat Pompe yang mengatakan : "Hukum Pidana Khusus mempunyai tujuan dan fungsi tersendiri" Undang-Undang Pidana yang dikualifikasikan sebagai Hukum Tindak Pidana Khusus ada yang berhubungan dengan ketentuan Hukum Administrasi 
Negara terutama mengenai penya-lahgunaan kewenangan. Tindak pidana yang menyangkut penyalahgunaan kewenangan ini terdapat dalam perumusan tindak pidana korupsi. ${ }^{73}$

Dasar hukum dan kekhususan Tindak Pidana Korupsi adalah. Undang-Undang Pidana yang masih dikualifikasikan sebagai Hukum Tindak Pidana Khusus adalah UndangUndang RI No, 7 Drt Tahun 1955 tentang (Hukum Pidana Ekonomi), Undang-Undang RI No. 31 tahun 1999 jo UndangUndang RI No. 20 tahn 2002 Tentang Pemberantasan Tindak Pidana Korupsi dan UU No $1 /$ Perpu/2002 dan UU No 2/Perpu/2002. Yang mana secara substantif digolongkan sebagai dasar tidak pidana korupsi/hukum tindak pidana khusus yang mengatur perbuatan tertentu ; Untuk orang/golongan tertentu hukum tindak pidana khusus menyimpang dari hukum pidana matriil dan hukum pidana formal. Penyimpangan diperlukan atas dasar kepentingan hukum. Dasar Hukum Undang-Undang Pidana Khusus mdilihat dari hukum pidana adalah Pasal 103 KUHP. Pasal 103 ini mengandung pengertian :

1. Semua ketentuan yang ada dalam Buku I KUHP berlaku terhadap UU di luar KUHP sepenjang UU itu tidak menentukan lain.

2. Adanya kemungkinan UU termasuk UU Pidana di luar KUHP, karena KUHP tidak mengatur seluruh tindak pidana di dalamnya (tidak lengkap dan tidak mungkin lengkap).

Korupsi sebagai tindak pidana khusus dapat dikaji dalam perspektif delik sebagai berukut:

1. Rumusan Delik Korupsi Sebagai Tindak Pidana Formiil: ${ }^{74}$

Perbuatan korupsi merupakan delik pidana formiil yaitu adanya tindak pidana korupsi cukup dengan dipenuhinya unsur-unsur perbuatan yang dirumuskan,

73 Andi Hamzah. 1983, Hukum Pidana Ekonomi. Erlangga Jakarta. Hal. $25-42$.

74 Ichwan B. A, 2010, Perumusan Delik (Perbuatan) Korupsi, Artikel, 11, August, hal. 2-15 http://wanspeak.wordpress.com/2010/08/11/319/. 
bukan dengan timbulnya akibat. Hal ini dijelaskan dalam UU No. 31 tahun 1999, meskipun hasil korupsi telah dikembalikan kepada negara, pelaku tindak pidana korupsi tetap diajukan ke pengadilan dan tetap dipidana, yakni tercantum dalam pasal 4: "Pengembalian kerugian keuangan negara atau perekonomian negara tidak menghapuskan dipidananya pelaku tindak pidana sebagaimana dimaksud dalam Pasal 2 dan Pasal 3." Kerugian keuangan negara yang dimaksud dalam pasal 4 yaitu kerugian seluruh kekayaan negara dalam bentuk apapun, yang dipisahkan atau yang tidak dipisahkan, termasuk didalamnya segala bagian kekayaan negara dan segala hak dan kewajiban yang timbul karena:

a. berada dalam penguasaan, pengurusan, dan pertanggungjawaban pejabat Negara, baik di tingkat pusat maupun daerah;

b. berada dalam penguasaan, pengurusan dan pertanggungjawaban Badan Usaha Milik Negara/Badan Usaha Milik Daerah, yayasan, badan hukum, dan perusahaan yang menyertakan modal negara, atau perusahaan yang menyertakan modal pihak ketiga berdasarkan perjanjian dengan Negara. Sedangkan yang dimaksud dengan Perekonomian Negara adalah kehidupan perekonomian yang disusun sebagai usaha bersama berdasarkan asas kekeluargaan ataupun usaha masyarakat secara mandiri yang didasarkan pada kebijakan Pemerintah, baik ditingkat pusat maupun di daerah sesuai dengan ketentuan peraturan perundang- undangan yang berlaku yang bertujuan memberikan manfaat, kemakmuran, dan kesejahteraan kepada Seluruh kehidupan masyarakat.

Seseorang baru dapat dikenakan tindak pidana korupsi menurut Undang-Undang bila seseorang dengan sengaja menggelapkan surat berharga dengan cara menjual saham tersebut secara melawan hukum yang disimpannya 
karena kekuasaaanya/jabatannya atau membiarkan saham tersebut diambil atau digelapakan oleh orang lain atau membantu dalam melakukan perbuatan tersebut (Pasal 8 Undang-Undang No. 20 Tahun 2001 tentang Perubahan atas Undang-Undang No. 31 Tahun 1999 tentang Pemberantasan Tindak Pidana Korupsi). Rumusan delik korupsi sebagai delik formiil juga disebutkan dalam pasal 2 yang berbunyi:

“(1). Setiap orang yang secara melawan hukum melakukan perbuatan memperkaya diri sendiri atau orang lain yang suatu korporasi yang dapat merugikan keuangan negara atau perekonomian negara, dipidana dengan pidana penjara seumur hidup atau pidana penjara paling singkat 4 (empat) tahun dan paling lama 20 (dua puluh) tahun dan denda paling sedikit Rp. 200.000.000.00 (dua ratus juta rupiah) dan paling banyak Rp. 1.000.000.000,00 (satu miliar rupiah)."

“(2). Dalam hal tindak pidana korupsi sebagaimana dimaksud dalam ayat (1) dilakukan dalam keadaan tertentu pidana mati dapat dijatuhkan." Yang dimaksud dengan "keadaan tertentu" dalam ketentuan ini adalah keadaan yang dapat dijadikan alasan pemberatan pidana bagi pelaku tindak pidana korupsi yaitu apabila tindak pidana tersebut dilakukan terhadap dana- dana yang diperuntukkan bagi penanggulangan keadaan bahaya, bencana alam nasional, penanggulangan akibat kerusuhan sosial yang meluas, penanggulangan krisis ekonomi dan moneter, dan pengulangan tindak pidana korupsi.

Dalam ketentuan ini, kata "dapat" sebelum frasa "merugikan keuangan atau perekonomian negara" menunjukkan bahwa tindak pidana korupsi merupakan delik formil, yaitu adanya tindak pidana korupsi cukup dengan dipenuhinya unsur-unsur perbuatan yang sudah dirumuskan bukan dengan timbulnya akibat. Dengan rumusan delik materiil formil pada Pasal 2 tersebut, sanksinya sudah dapat dijatuhkan jika unsur melawan 
hukumnya telah dipenuhi. Hal ini juga dijelaskan dalam Pasal 4 undang-undang tersebut yang menyatakan bahwa pengembalian kerugian keuangan negara tidak menghapus unsur pidananya.

\section{Rumusan Delik Korupsi Sebagai Tindak Pidana Materiil} (Pidana Substantif): ${ }^{75}$

Agar dapat menjangkau berbagai macam perbuatan penyimpangan keuangan negara atau perekonomian negara yang semakin canggih dan rumit, maka tindak pidana yang diatur dalam Undang-undang ini dirumuskan sedemikian rupa sehingga meliputi perbuatan-perbuatan memperkaya diri sendiri atau orang lain atau suatu badan (korporasi) secara "melawan hukum" dalam pengertian formil dan materiil. Dengan perumusan tersebut, pengertian melawan hukum dalam tindak pidana korupsi dapat pula mencakup perbuatan-perbuatan tercela yang menurut masyarakat harus dituntut dan dipidana. Penjelasan Pasal 2 ayat (1), yang dimaksud dengan "secara melawan hukum" dalam pasal ini mencakup perbuatan melawan hukum dalam arti formil maupun dalam arti materiil, yaitu walaupun perbuatan tersebut tidak diatur dalam peraturan perundang-undangan, namun apabila perbuatan tersebut dianggap tercela karena tidak sesuai dengan rasa keadilan atau norma-norma kehidupan sosial dalam masyarakat, maka perbuatan tersebut dapat dipidana. Rumusan tindak pidana korupsi yang diatur dalam Undang-undang Nomor 3 Tahun 1971 dalam prakteknya sering ditafsirkan sebagai delik materiil, yakni delik yang selesai jika telah timbul akibat merugikan keuangan negara atau perekonomian negara. Sehingga, apabila pelaku mengembalikan hasil korupsi yang dilakukan, maka unsur kerugian negara dianggap sudah tidak ada lagi, sehingga pelaku tindak pidana korupsi tidak diajukan ke pengadilan atau dipidana. Sebaliknya, dengan delik formil yang dianut Undang-undang Nomor 31 Tahun 1999 yang telah diubah 
oleh Undang-Undang Nomor 20 tahun 2001, meskipun hasil korupsi telah dikembalikan kepada negara, pelaku tindak pidana korupsi tetap diajukan ke pengadilan dan dapat dipidana.

3. Rumusan Delik Korupsi Sebagai Delik Pidana Khusus Dalam Pasal 15 Undang-Undang RI No. 31 tahun 1999 yang berbunyi: ${ }^{76}$

"Setiap orang yang melakukan percobaan, pembantuan, atau permufakatan jahat untuk melakukan tindak pidana korupsi, dipidana dengan pidana yang sama sebagaimana dimaksud dalam Pasal 2, Pasal 3, Pasal 5 sampai dengan Pasal 14."

Dari berbagai penjelasan diatas, dapatlah pada substansi bahwa secara hukum materil dan formil dalam hukum pidana, telah meberikan legitimasi secara hukum bahwa korupsi merupakan salah satu bagian dari tindak pidana khusus di Indonesia. 


\section{BAB IV \\ LEMBAGA PENEGAKAN HUKUM \\ DALAM SISTEM PERADILAN PIDANA \\ DI INDONESIA}

\section{A. Sistem Peradilan Pidana Di Indonesia}

Proses penyelesaian perkara pidana berdasarkan hukum yang berlaku di Indonesia saat ini dilakukan dalam suatu sistem peradilan pidana (Criminal justice system). Sistem Peradilan Pidana atau Criminal Justice System kini telah menjadi suatu istilah yang menunjukan mekanisme kerja dalam penanggulangan kejahatan dengan mempergunakan dasar pendekatan sistem. Istilah criminal justice system menurut Ramington dan Ohlin sebagaimana dikutip oleh Romli Atmasasmita adalah sebagai berikut: ${ }^{77}$

Criminal justice sytem dapat diartikan sebagai pemakaian pendekatan sistem terhadap mekanisme administrasi peradilan pidana, dan peradilan pidana sebagai suatu sistem merupakan hasil interaksi antara peraturan perundang-undangan, praktik administrasi dan sikap atau tingkah laku sosial. Pengertian sistem itu sendiri mengandung implikasi suatu proses interaksi yang dipersiapkan secara rasional dan dengan cara efisien untuk memberikan hasil tertentu dengan segala keterbatasannya.

Marjono Reksodipoetro memberikan batasan bahwa sistem peradilan pidana adalah sistem pengendalian kejahatan yang terdiri dari lembaga-lembaga kepolisian, kejaksaan, pengadilan, dan lembaga pemasyarakatan. ${ }^{78}$ Berdasarkan apa yang dikemukakan oleh Marjono tersebut terlihat bahwa komponen atau sub sistem dalam sistem peradilan pidana adalah kepolisian, kejaksaan, pengadilan dan lembaga pemasyarakatan. 
Selanjutnya Marjono juga mengemukakan bahwa tujuan dari sistem peradilan pidana adalah mencegah masyarakat menjadi korban kejahatan, menyelesaikan kasus kejahatan yang terjadi sehingga masyarakat puas bahwa keadilan telah ditegakkan dan yang bersalah diadili, mengusahakan agar mereka yang pernah melakukan kejahatan tidak lagi mengulangi perbuatannya. ${ }^{79}$

Muladi mengemukakan bahwa sistem peradilan pidana merupakan suatu jaringan (network) peradilan yang menggunakan hukum pidana materiil, hukum pidana formal maupun hukum pelaksanaan pidana. Namun kelembagaan ini harus dilihat dalam konteks sosial. ${ }^{80} \mathrm{Hal}$ ini dimaksudkan untuk mencapai keadilan sesuai dengan apa yang dicitacitakan oleh masyarakat.

Menurut Romli Atmasasmita, dengan diundangkannya undang-undang No. 8 tahu 1981 tentang Acara pidana, menjadikan sistem peradilan pidana Indonesia menganut sistem akusator dan terpengarung oleh Due process model. ${ }^{81}$ Konsep Due Process model sangat menjunjung tinggi supremasi hukum, dalam perkara pidana tidak seorang pun berada dan menempatkan diri diatas hukum. Sistem akusator adalah suatu sistem yang menitik beratkan pembuktian dengan saksi dan bukti nyata. ${ }^{82}$

Konsep Due process model sangat menjunjung asas Presumption of innocence. Menurut konsep ini setiap pemeriksaan baik di tingkat penyidikan, penuntutan, maupun pemeriksaan di sidang pengadilan harus mengikuti prosedur formal sebagaimana yang telah ditetapkan oleh undangundang. adapun nilai-nilai yang melandasi due process model ini adalah: ${ }^{83}$

79 Ibid., hal. 3.

80 Ibid., hal. 5-6.

81 Trisno Raharjo, 2011, Mediasi Pidana Dalam Sistem Peradilan Pidana: Suatu Kajian Perbandingan dan Penerapannya di Indonesia, Buku Litera: Jogjakarta, hal. 1.

82 Ibid., hal. 6.

83 Ibid., hal. 5. 
1. Mengutamakan formal adjudicative dan adversary fact-finding. Hal ini berarti bahwa seorang tersangka harus diajukan ke muka pengadilan yang tidak memihak dan diperiksa sesudah tersangka memperoleh hanya secara penuh untuk melakukan pembelaan

2. Menekankan pada pencegahan dan menghapuskan sejauh mungkin kesalahan mekanisme administrasi peradilan.

3. Proses peradilan harus dikendalikan agar dapat dicegah penggunaannya sampai pada titik optimum karena keuasaan cenderung disalahgunakan atau memilih potensi untuk menempatkan individu pada kekuasaan yang koersif dari Negara.

4. Memegang teguh doktrin legal audit, yakni:

a. Seorang dianggap bersalah apabila penetapan kesalahannya dilakukan secara procedural dan dilakukan oleh mereka yang memiliki kewenangan untuk itu

b. Seseorang tidak dapat dianggap bersalah sekalipun kenyataan akan memberatkan jika perlindungan hukum yang diberikan undang-undang kepada orang yang bersangkutan tidak efektif penetapan kesalahan seseorang hanya dapat dilakukan oleh pengadilan yang tidak memihak:

1) Gagasan persamaan kedudukan di muka hukum lebih diutamakan

2) Lebih mengutamakan kesusilaan dan kegunaan sanksi pidana.

Sehingga Sistem peradilan pidana pada hakekatnya merupakan suatu proses penegakan hukum pidana. Oleh karena itu sistem peradilan pidana sangat terkait erat dengan perundang-undangan pidana itu sendiri, baik hukum pidana materiil maupun hukum pidana formil (acara pidana). Dalam hal ini sistem peradilan pidana adalah merupakan bentuk perwujudan penegakkan hukum "in concreto", sedangkan 
perundang-undangan merupakan perwujudan penegakkan hukum "in concreto" oleh penegak hukum.

\section{B. Lembaga Penegak Hukum dalam Sistem Peradilan Pidana di Indonesia}

Sistem Peradilan Pidan dikenal dengan tiga bentuk pendekatan yaitu: ${ }^{84}$

1. Pendekatan Normatif, memandang keempat aparatur penegak hukum (kepolisian, kejaksaan, pengadilan dan lembaga pemasyarakatan) sebagai institusi pelaksana peraturan perundang-undangan yang berlaku sehingga keempat aparatur tersebut marupakan bagian yang tidak terpisahkan dari sistem penegakan hukum semata-mata.

2. Pendekatan Administratif, memandang keempat aparatur penegak hukum sebagai suatu organisasi managemen yang memiliki mekanisme kerja, baik hubungan yang bersifat horisontal maupun yang bersifat vertikal sesuai dengan struktur organisasi yang berlaku dalam organisasi tersebut

3. Pendekatan Sosial, memandang keempat aparatur penegak hukum merupakan bagian yang tidak terpisahkan dari suatu sistem sosial sehingga masyarakat secara keseluruhan ikut bertanggung jawab atas keberhasilan atau ketidak berhasilan dari keempat aparatur penegak hukum tersebut dalam melaksanakan tugasnya.

Dari substansi pendekatan sistem peradilan pidana diatas, menjelaskan adanya bentuk komponen sebagai wujud kongkrit struktur penegakan hukum pidana atau bentuk ideal lembaga penegak hukum pidana. Komponen yang lazim diakui baik dalam kebijakan pidana (criminal policy) maupun dalam praktek:

1. Kepolisian

2. Kejaksaan

3. Pengadilan

84 A.Azis Maulana, 2013, Criminal Justice System Sistem Peradilan Pidana, Materi Kuliah Pada STIH sunan Giri, Malang, hal. 3. 


\section{Lembaga Pemasyarakatan}

Pendapat yang lain (Negel \& Romli Atmasasmita) memasukkan komponen "pembuat undang-undang dan penasihat hukum", dengan alasan :

1. Bahwa peran pembuat undang-undang justru sangat menentukan dalam politik kriminal (criminal policy) yaitu menentukan arah kebijakan hukum pidana dan hukum pelaksanaan pidana yang hendak ditempuh dan sekali gus menjadi tujuan dari penegakan hukum.

2. Bahwa keberhasilan penegakan hukum dalam kenyataannya dipengaruhi juga oleh peranan dan tanggungjawab para kelompok penasihat hukum. Peradilan yang cepat, sederhana dan jujur bukan sematamata ditujukan kepada keempat komponen penegak hukum saja, melainkan juga ditujukan kepada kelompok penasihat hukum sebagai komponen (baru) kelima.

Aplikasi atau penegakan hukum pidana yang tersedia tersebut dilaksanakan oleh instrumen-instrumen yang diberi wewenang oleh Undang Undang untuk melaksanakan kewenangan dan kekuasaannya masing-masing dan harus dilakukan dalam suatu upaya yang sistematis untuk dapat mencapai tujuannya. Upaya yang sistematis ini dilakukan dengan mempergunakan segenap unsur yang terlibat di dalamnya sebagai suatu kesatuan dan saling berhubungan (interelasi), serta saling mempengaruhi satu sama lain. Upaya yang demikian harus diwujudkan dalam sebuah sistem yang bertugas menjalankan penegakan hukum pidana tersebut, yaitu Sistem Peradilan Pidana (Criminal Justice Sytem) yang pada hakikatnya merupakan "sistem kekuasaan menegakkan hukum pidana". 85

Oleh karena itu, setiap aparat dari sistem peradilan pidana (criminal justice system) harus selalu mengikuti

85 Barda Nawawi Arief, 2001, Masalah Penegakan Hukum dan Kebijakan Penanggulangan Kejahatan, Citra Adtya Bakti, Bandung. hal. 28. 
perkembangan dari setiap perundang-undangan yang terbit karena aparat dalam sistem peradilan pidana tersebut "menyandarkan" profesinya pada hukum pidana dalam upaya mengantisipasi kejahatan yang terjadi.

Sistem Peradilan Pidana ini diwujudkan / diimplementasikan dalam 4 (empat) sub sistem, yaitu :

1. Kekuasaan "Penyidikan" oleh lembaga penyidik;

2. Kekuasaan Penuntutan oleh lembaga penuntut umum;

3. Kekuasaan mengadili dan menjatuhkan putusan oleh badan pengadilan;

4. Kekuasaan pelaksanaan putusan/pidana oleh badan/aparat pelaksana/eksekusi. ${ }^{86}$

Demikian, maka dapat dilihat masing-masing kewenangan lembaga penegak hukum yang merupakan sub sistem dalam Sistem Peradilan Pidana tersebut merupakan kekuasaan yang merdeka/independent dalam arti bebas dari pengaruh penguasa atau dari tekanan dari pihak luar. Akan tetapi kemandirian tersebut tidak bersifat parsial (fragmenter), tetapi kemandirian dalam satu sistem, yaitu Sistem Peradilan Pidana yang integral (Integrated Criminal Justice System). 87 Adapun implementasi dari masing-masing sub sistem dalam Sistem Peradilan Pidana tersebut adalah sebagai berikut :

\section{Kekuasaan Penyidikan oleh lembaga penyidik;}

Berdasarkan Kitab Undang Undang Hukum Acara Pidana (KUHAP) / UU No. 8 1981, Pasal 1 angka, maka yang dimaksud dengan Penyidik adalah Pejabat Polisi Negera Republik Indonesia atau Pejabat Pegawai Negeri Sipil (PPNS) tertentu yang diberi wewenang khusus oleh undang-undang untuk melakukan penyidikan. Dengan demikian, secara umum yang diberi kewenangan untuk melakukan penyidikan suatu tindak pidana adalah Kepolisian Republik Indonesia (POLRI), namun untuk

86 Ibid.

87 Barda Nawawi Arief, 2003, Sistem Peradilan Pidana Terpadu dalam Kaitannya dengan Pembaruan Kejaksaan, dalam Media Hukum Vol. 2 Nomor 1, Tahun 2003, hal 30. 
tindak pidana tertentu ada juga lembaga lain yang diberi kewenangan untuk melakukan penyidikan, seperti :

a. Kejaksaan untuk Tindak Pidana Korupsi dan Tindak Pidana HAM ;

b. Aparat Dirjen Pajak untuk Tindak Pidana Perpajakan;

c. Aparat Bea Cukai untuk Tindak Pidana Kepabeanan;

d. Aparat Kehutanan untuk Tindak Pidana Kehutanan.

a. Kekuasaan Penuntutan oleh lembaga penuntut umum;

Apabila dalam Kekuasaan Penyidikan, terdapat beberapa lembaga yang dapat melakukan penyidikan, maka dalam menjalankan kekuasaan penuntutan hanya satu lembaga yang berwenang melaksanakan yaitu lembaga Kejaksaan Republik Indonesia. Hal tersebut tertuang dalam Ketentuan Umum KUHAP angka 6 dan angka 7 serta tecantum pula dalam Undang Undang Nomor 16 Tahun 2004 tentang Kejaksaan Republik Indonesia pada Pasal 2 ayat (1) yang menyebutkan bahwa "Kejaksaan Republik Indonesia yang selanjutnya dalam Undang Undang ini disebut Kejaksaan adalah lembaga pemerintahan yang melaksanakan kekuasaan Negara di bidang penuntutan serta kewenangan lain berdasarkan undang-undang."

\section{b. Kekuasaan mengadili dan menjatuhkan putusan oleh} badan pengadilan;

Yang dimaksud dengan Kekuasaan mengadili sebagaimana diatur dlam Pasal 1 angka 9 KUHAP adalah serangkaian tindakan hakim untuk menerima, memeriksa dan memutus perkara pidana berdasarkan asas bebas, jujur dan tidak memihak di sidang pengadilan dalam hal dan menurut cara yang diatur dalam undang-undang ini. Selanjutnya berdasarkan Pasal 1 angka 8 KUHAP, yang diberi wewenang ini adalah Hakim sebagai Pejabat Peradilan Negara yang diberi wewenang oleh undang-undang untuk mengadili. 
c. Kekuasaan pelaksanaan putusan/pidana oleh badan/aparat pelaksana/eksekusi:

Kekuasaan ini dimiliki oleh Jaksa Penuntut Umum karena di samping berwenang melaksanakan penuntutan, Jaksa Penuntut Umum juga berwenang melaksanakan penetapan hakim dan putusan pengadilan yang telah memperoleh kekuatan hukum tetap. Hal tersebut diatur dalam Ketentuan Umum KUHAP Pasal 1angka 6 dan angka 7 serta juga diatur dalam Pasal 30 Undang Undang Nomor 16 tahun 2004 tentang Kejaksaan Republik Indonesia.

Dengan demikian dalam proses penegakan hukum pidana, unsur-unsur sistem peradilan pidana meliputi : Kepolisian, Kejaksaan, Pengadilan dan Lembaga Pemasyarakatan. Keempat unsur inilah yang merupakan sub-sistem dari sistem peradilan pidana, sehingga keberhasilan upaya penegakan hukum sangat dipengaruhi oleh keterkaitan dan ketergantungan keempat unsur tersebut. Oleh karena itu, Yang dimaksud dengan sistem peradilan pidana dapat juga dikatakan sebagai sistem pengendalian kejahatan yang terdiri dari lembaga-lembaga Kepolisian, Kejaksaan, Pengadilan dan Pemasyarakatan terpidana. ${ }^{88}$

\section{Mekanisme / Tata Acara Penegakan Hukum Dalam Sistem Peradilan Pidana Di Indonesia.}

UU No. 8 tahun 1981 atau dikenal sebagai Kitab Undangundang Hukum Acara Pidana (KUHAP), terdiri atas 22 bab disertai penjelasannya secara lengkap. Isi undang-undang menunjukkan sistematika dan mekanisme sistem peradilan pidana adalah sebagai berikut:

Bab I : Ketentuan Umum. Pasal 1

Bab II : Ruang Lingkup Berlakunya Undang-undang.

Pasal 2

88 Mardjono Reksodiputro, 1993, Sistem Peradilan Pidana di Indonesia, Pidato Pengukuhan Guru Besar tetap dalam Ilmu Hukum pada Fakultas Hukum Universitas Indonesia, hal.1. 


$\begin{array}{ll}\text { Bab III } & \text { : Dasar Peradilan. Pasal } 3 \\ \text { Bab IV } & \text { : Penyidik dan Penuntut Umum. Pasal } 4 \text { s/d } 15 \\ & - \text { Bagian Kesatu : Penyelidik dan Penyidik. } \\ & \text { Psl.4 s/d } 9 \\ - & \text { Bagian kedua } \quad \text { : Penyidik Pembantu. Psl. } 10 \\ & \text { s/d } 12 \\ - & \text { Bagian ketiga } \quad \text { : Penuntut Umum. Psl. } 13 \\ & \text { s/d } 15 .\end{array}$

Bab V : Penangkapan, Penahanan, Penggeledahan, Badan Pemasukan Rumah, Penyitaan dan Pemeriksaan Surat.

- Bagian kesatu : Penangkapan. Psl. 16 s/d. 19

- Bagian kedua : Penahanan. Psl. 20 s/d. 31

- Bagian ketiga : Penggeledahan. Psl. 32 s/d. 37

- Bagian keempat : Penyitaan. Psl. 38 s/d. 46

- Bagian kelima : Pemeriksaan Surat. Psl.47 s/d. 49

Bab VI : Tersangka dan terdakwa. Pasal $50 \mathrm{~s} / \mathrm{d} .68$

Bab VII : Bantuan Hukum. Pasal. 69 s/d. 74

Bab VIII : Berita Acara. Pasal 75

Bab IX : Sumpah atau Janji. Pasal. 76

Bab X : Wewenang Pengadilan untuk Mengadili

- Bagian kesatu : Pra-peradilan. Psl. 77 s/d. 83

- Bagian kedua : Pengadilan Negeri. Psl. 84 s/d. 86

- Bagian ketiga : Pengadilan Tinggi. Ps1. 87

- Bagian keempat : Mahkamah Agung. Psl. 88

Bab XI : Koneksitas. Pasal 89 s/d. 94

Bab XII : Ganti Kerugian dan Rehabilitasi

- Bagian kesatu : Ganti Kerugian. Psl. 95 s/d. 96

- Bagian kedua : Rehabilitasi. Psl. 97

Bab XII : Penggabungan Perkara Gugatan Ganti Kerugian. Psl.98 s/d. 101.

Bab XIV : Penyidikan

- Bagian kesatu : Penyelidikan. Psl. 102 s/d. 105 
- Bagian kedua : Penyidikan. Psl. 106 s/d. 136

Bab XV : Penuntutan. Pasal. 137 s/d. 144

Bab XVI : Pemeriksaan di Sidang Pengadilan

- Bagian kesatu : Panggilan dan Dakwaan Psl. $145 \mathrm{~s} / \mathrm{d} .146$

- Bagian kedua : Memutuskan sengketa mengenai wewenang mengadili. Psl. 147 s/d.151.

- Bagian ketiga : Acara pemeriksaan biasa. Psl.152 s/d. 182

- Bagian keempat : Pembuktian dan pemutusan dalam acara pemeriksaan biasa. Psl. 183 s/d. 202

- Bagian kelima : Acara pemeriksaan singkat. Psl. 203 s/d. 204.

- Bagian keenam : Acara Pemeriksaan Cepat.

Paragraf 1 : Acara pemeriksaan Tindak Pidana Ringan. Psl. $205 \mathrm{~s} / \mathrm{d}$.

Paragraf 2 : Acara Pemeriksaan Perkara Pelanggaran Lalu Lintas Jalan. Psl. 211 s/d. 216

- Bagian ketujuh : Pelbagai ketentuan. Psl. 217 s/d.232.

Bab XVII : Upaya Hukum Biasa

- Bagian kesatu : Pemeriksaan Tingkat Banding. Psl. 233 s/d. 243.

- Bagian kedua : Pemeriksaan untuk Kasasi. Psl. 244 s/d. 258.

Bab XVIII : Upaya Hukum Luar Biasa

Bagian kesatu : Pemeriksaan Tingkat Kasasi demi kepentingan hukum. Psl. 259 s/d. 262.

Bagian kedua : Peninjauan kembali Putusan Pengadilan yang telah memperoleh kekuatan hukum tetap. Psl. 263 s/d. 269.

Bab XIX : Pelaksanaan Putusan Pengadilan. Psl. 270 s/d 276 
Bab XX : Pengawasan dan Pengamatan Pelaksanaan Putusan Pengadilan.

Psl. 277 s/d. 283.

Bab XXI : Ketentuan Peralihan. Pasal. 284.

Bab XXII : Ketentuan Penutup. Psal 285 s/d. 286.

Oleh karena itu Mekanisme peradilan pidana sebagai suatu proses, atau disebut "criminal Justice Proses", dimulai dari proses penangkapan, penggeledahan, penahanan, penuntutan dan pemeriksaan di muka sidang pengadilan, serta diakhiri dengan pelaksanaan pidana di lembaga pemasyarakatan. 


\section{BAB V \\ SISTEM PERADILAN TINDAK PIDANA KORUPSI DI INDONESIA}

Sistem peradilan pidana lahir untuk menanggulangi dan mencegah kejahatan. Sebagai suatu "proses" maka "the criminal justice process" melibatkan lembaga-lembaga dan prosedurprosedur yang dibuat untuk menangani kejahatan dan orangorang yang disangka melakukan kejahatan itu. Sistem ini bertujuan untuk menanggulangi kejahatan hingga sampai batas yang dapat ditoleransi masyarakat, sebab untuk menghilangkan sama sekali kejahatan merupakan hal yang mustahil. Dalam sistem ini bekerja para penegak hukum (law enforcement agencies) yang sesuai fungsi, tugas dan wewenang masing-masing bekerja bersama untuk mencapai tujuan tadi. Agar mereka dapat bekerja dengan baik, harus dibuat kerangka hukum yang mengatur bagaimana sistem ini bekerja. Dalam penjelasan di atas, sistem peradilan pidana mencakup tiga komponen: (1) penegak hukum;

(2) proses peradilan (hakim, jaksa penuntut umum, dan pengacara); dan pemasyarakatan (petugas LP, petugas pelepasan bersyarat, dan petugas pengawas hukuman percobaan). Institusi yang bekerja dalam sistem ini (dapat juga disebut sub-sistem) pada umumnya adalah kepolisian, kejaksaan, dan pengadilan. Dalam tindak pidan korupsi, terdapat institusi Komisi Pemberantasan Korupsi (KPK) untuk menanggulangi kejahatan korupsi.

\section{A. Peradilan Tindak Pidana Korupsi}

Di dalam Undang-Undang No. 46 Tahun 2009 tentang Pengadilan Tindak Pidana Korupsi juga diatur tentang hukum acara yang dalam beberapa hal berbeda dengan hukum acara umum Dalam undang-undang dinyatakan bahwa pemeriksaan di sidang Pengadilan Tindak Pidana Korupsi dilakukan berdasarkan hukum acara pidana yang berlaku, kecuali ditentukan lain dalam undang-undang ini 
(Pasal 25). Perkara 
tindak pidana korupsi diperiksa, diadili, dan diputus oleh Pengadilan Tindak Pidana Korupsi tingkat pertama dalam waktu paling lama 120 hari kerja terhitung sejak tanggal perkara dilimpahkan ke Pengadilan Tindak Pidana Korupsi (Pasal 29). Pasal 30 hingga Pasal 32 juga mengatur mengenai batasan waktu. Untuk pemeriksaan tingkat banding tindak pidana korupsi diperiksa dan diputus dalam jangka waktu paling lama 60 hari kerja terhitung sejak tanggal berkas perkara diterima oleh Pengadilan Tinggi (Pasal 30). Pemeriksaan tingkat kasasi tindak pidana korupsi diperiksa dan diputus dalam jangka waktu paling lama 120 hari kerja terhitung sejak tanggal berkas perkara diterima oleh Mahkamah Agung (Pasal 31). Dalam hal putusan pengadilan dimintakan peninjuan kembali, pemeriksaan perkara tindak pidana korupsi diperiksa dan diputus dalam waktu paling lama 60 hari kerja terhitung sejak tanggal berkas perkara diterima oleh Mahkamah Agung (Pasal 32).

Di luar Undang-Undang Pengadilan Tindak Pidana Korupsi (Undang-Undang No. 46 tahun 2009) di atas, kita juga harus melihat ketentuan dalam Undang-Undang Komisi Pemberantasan Korupsi (Undang-Undang No. 30 Tahun 2002). Di dalam upaya penanggulangan korupsi, Komisi Pemberan- tasan Korupsi didukung dengan ketentuan yang bersifat strategis antara lain: 1) perluasan alat bukti yang sah serta ketentuan tentang asas pembuktian terbalik; 2) wewenang untuk penyelidikan, penyidikan, dan penuntutan terhadap penyelenggara negara, tanpa ada hambatan prosedur karena statusnya selaku pejabat negara. Mengenai hukum acara dalam memproses perkara tindak pidana korupsi secara lebih luas diatur di dalam Undang-Undang No. 20 Tahun 2001 jo Undang-Undang No. 31 Tahun 1999. Khusus mengenai alat bukti, menurut undang-undang ini, alat bukti petunjuk mengalami perluasan, yaitu di samping yang diperoleh dari keterangan saksi, surat, dan keterangan terdakwa, juga diperoleh dari alat bukti lain yang berupa informasi yang diucapkan, dikirim, diterima, atau disimpan secara elektronik 
dengan alat optik atau yang serupa dengan itu tetapi tidak terbatas pada data penghubung elektronik (electronic data interchange), surat elektronik (e-mail), telegram, teleks, dan faksmili, dan dari dokumen, yakni setiap rekaman data atau informasi yang dapat dilihat, dibaca dan atau didengar yang dapat dikeluarkan dengan atau tanpa bantuan suatu sarana, baik yang tertuang di atas kertas, benda fisik apapun selain kertas, maupun yang terekam secara elektronik, yang berupa tulisan, suara, gambar, peta, rancangan, foto, huruf, tanda, angka, atau perforasi yang memiliki makna.

Adapun bentuk umum dalam penanganan tindak pidana korupsi adalah sebagai berikut:

1. Penyelidikan (Undang Undang Nomor 8 Tahun 1981

Penyelidikan (pasal 1 ayat 5) Penyelidikan adalah serangkaian tindakan penyelidik untuk mencari dan menemukan suatu peristiwa yang diduga sebagai tindak pidana guna menentukan dapat atau tidaknya dilakukan penyidikan menurut cara yang diatur dalam undangundang ini. Penyelidikan dilakukan oleh Polisi dan khusus TIPIKOR juga dilakukan oleh Jaksa (pasal 284 KUHP dan KPK (pasal 6 Undang Undang no 30 Tahun 2002).

2. PENYIDIKAN (Undang Undang Nomor 8 Tahun 1981 /KUHAP)

Penyidikan (pasal 1 ke 2 KUHAP) Penyidikan adalah serangkaian tindakan penyidik dalam hal dan menurut cara yang diatur dalam undang-undang ini untuk mencari serta mengumpulkan bukti yang dengan bukti itu membuat terang tentang tindak pidana yang terjadi dan guna menemukan tersangkanya. Penyidikan dilakukan oleh Penyidik (polri, jaksa dan KPK dalam pasal 6 Undang Undang no 30 Tahun 2002)

3. PENUNTUTAN (Pasal 1 Ke 7 Undang Undang Nomor 8 Tahun 1981 /KUHAP)

Penuntutan adalah tindakan penuntut umum untuk melimpahkan perkara pidana ke pengadilan negeri yang berwenang dalam hal dan menurut cara yang diatur dalam 
undang-undang ini dengan permintaan supaya diperiksa dan diputus oleh hakim di sidang pengadilan. Penuntutan dilakukan oleh Jaksa penuntut Umum pada kejaksaan ( Pasal 1 Ke 8 KUHAP) atau pada KPK Pasal 6 UU KPK).

4. Peradilan/Proses Mengadili (Pasal ke 9 Undang Undang Nomor 8 Tahun 1981/KUHAP)

Mengadili adalah serangkaian tindakan hakim untuk menerima, memeriksa, dan memutus perkara pidana berdasarkan asas bebas, jujur, dan tidak memihak di sidang pengadilan dalam hal dan menurut cara yang diatur dalam undang-undang ini. Hakim adalah pejabat peradilan negara yang diberi wewenang oleh undang-undang untuk mengadili. (pasal 1 ke 8 )

a. Peradilan Tingkat pertama Pada Pengadilan Negeri

b. Peradilan Banding pada Pengadilan Tinggi

c. Peradilan Kasasi pada Mahkamah Agung

\section{B. Hukum Acara atau Tahapan Sistem Peradilan Tindak Pidana Korupsi}

Proses ini dimulai apabila terdapat laporan dari sesorang atau informasi yang diterima oleh Kepolisian, Kejaksaan dan KPK tentang adanya dugaan telah terjadinya perbuatan yang merugikan keuangan negara dan perekonomian negara yang dilakukan secara melawan hukum atau penyalahgunaan kekuasaan seorang pejabat, atau perbuatan curang yang dilakukan pengusaha dan pemberian serta penerimaan gratifikasi oleh pejabat negara.

\section{Proses Penyelidikan (Pulbaket)}

Berdasarkan laporan atau informasi yang diterima oleh Penyelidik maka, penyelidik melakukan pengumpulan keterangan dan barang bukti. Untuk memastikan bahwa perbuatan yang dilaporkan tersebut merupakan perbuatan melawan hukum atau menyalahgunakan kekuasaan atau perbuatan curang yang menimbulkan kerugian keuangan atau perekonomian negara, atau perbuatan gratifikasi. Apabila penyelidik setelah mendapatkan keterangan dan barang bukti beranggapan bahwa perbuatan merupakan 
perbuatan pidana korupsi, maka pemeriksaan dilanjutkan pada tahap penyidikan namun apabila dugaan tersebut tidak didukung oleh keterangan dan barang bukti maka kausus diberhentikan. Pada tahap ini belum ada orang yang disangkakan sebagai pelaku. Mereka yang memberikan keterangan biasanya disebut sebagai terperiksa. Oleh karena itu belum ada proses pemberian bantuan hukum.

a. Pasal 43 (undang-Undang Nomor 30 Tahun 2002)

(1) Penyelidik adalah Penyelidik pada Komisi Pemberantasan Korupsi yang diangkat dan diberhentikan oleh Komisi Pemberantasan Korupsi.

(2) Penyelidik sebagaimana dimaksud pada ayat (1) melaksanakan fungsi penyelidikan tindak pidana korupsi.

b. Pasal 44 :

(1) Jika penyelidik dalam melakukan penyelidikan menemukan bukti permulaan yang cukup adanya dugaan tindak pidana korupsi, dalam waktu paling lambat 7 (tujuh) hari kerja terhitung sejak tanggal ditemukan bukti permulaan yang cukup tersebut, penyelidik melaporkan kepada Komisi Pemberantasan Korupsi.

\section{Penyelidikan lebih lanjut oleh KPK}

a. Proses Penyidikan

Apabila penyidik berpendapat bahwa perbuatan tersebut merupakan perbuatan tindak pidana korupsi, maka tahapan selanjutnya adalah tahap untuk mengumpulkan alat bukti dan menemukan tersangkanya. Agar tugasnya dapat dilaksanakan maka penyidik diberikan wewenag, yaitu;

1) Pasal 7 :

(1) Penyidik sebagaimana dimaksud dalam Pasal 6 ayat (1) huruf a karena kewajibannya mempunyai wewenang :

(a) menerima Laporan atau pengaduan dari seorang tentang adanya tindak pidana; 
(b) melakukan tindakan pertama pada saat di tempat kejadian;

(c) menyuruh berhenti seorang tersangka dan memeriksa tanda pengenal diritersangka;

(d) melakukan penangkapan, penahanan, penggeledahan dan penyitaan;

(e) melakukan pemeriksaan dan penyitaan surat;

(f) mengambil sidik jari dan memotret seorang;

(g) memanggil orang untuk didengar dan diperiksa sebagai tersangka atau saksi;

(h) mendatangkan orang ahli yang diperlukan dalam hubungannya dengan pemeriksaan perkara;

(i) mengadakan penghentian penyidikan;

(j) mengadakan tindakan lain menurut hukum yang bertanggung jawab.

(2) Bukti permulaan yang cukup dianggap telah ada apabila telah ditemukan sekurang-kurangnya 2 (dua) alat bukti, termasuk dan tidak terbatas pada informasi atau data yang diucapkan, dikirim, diterima, atau disimpan baik secara biasa maupun elektronik atau optik.

(3) Dalam hal penyelidik melakukan tugasnya tidak menemukan bukti permulaan yang cukup sebagaimana dimaksud pada ayat (1), penyelidik melaporkan kepada Komisi Pemberantasan Korupsi dan Komisi Pemberantasan Korupsi menghentikan penyelidikan.

(4) Dalam hal Komisi Pemberantasan Korupsi berpendapat bahwa perkara tersebut diteruskan, Komisi Pemberantasan Korupsi melaksanakan penyidikan sendiri atau dapat melimpahkan perkara tersebut kepada penyidik kepolisian atau kejaksaan. 
(5) Dalam hal penyidikan dilimpahkan kepada kepolisian atau kejaksaan sebagaimana dimaksud pada ayat (4), kepolisian atau kejaksaan wajib melaksanakan koordinasi dan melaporkan perkembangan penyidikan kepada Komisi Pemberantasan Korupsi.

(6) Penyidik sebagaimana dimaksud dalam Pasal 6 ayat (1) huruf $b$ mempunyai wewenang sesuai dengan undang-undang yang menjadi dasar hukumnya masing-masing dan dalam pelaksanaan tugasnya berada di bawah koordinasi dan pengawasan penyidik tersebut dalam Pasal 6 ayat (1) hurufa.

(7) Dalam melakukan tugasnya sebagaimana dimaksud dalam ayat (1) dan ayat (2), penyidik wajib menjunjung tinggi hukum yang berlaku.

2) Pasal 8

(1) Penyidik membuat berita acara tentang pelaksanaan tindakan sebagaimana dimaksud dalam Pasal 75 dengan tidak mengurangi ketentuan lain dalam undang-undang ini.

(2) Penyidik menyerahkan berkas perkara kepada penuntut umum.

(3) Penyerahan berkas perkara sebagaimana dimaksud dalam ayat (2) dilakukan:

(a) pada tahap pertama penyidik hanya menyerahkan berkas perkara;

(b) dalam hal penyidikan sudah dianggap selesai, penyidik menyerahkan tanggung jawab atas tersangka dan barang bukti kepada penuntut umum.

3) Pasal 9

Penyelidik dan penyidik sebagaimana dimaksud dalam Pasal 6 ayat (1) huruf a mempunyai wewenang melakukan tugas masingmasing pada umumnya di seluruh wilayah Indonesia, khususnya 
di daerah hukum masing-masing di mana ia diangkat sesuai dengan ketentuan undang-undang.

Alat bukti yang harus dikumpulkan oleh penyidik adalah minimal dua alat bukti diantara alat bukti seperti diatur di dalam Pasal 184 KUHAP, yaitu;

(1) Alat bukti yang sahialah:

(a) keterangan saksi;

(b) keterangan ahli;

(c) surat;

(d) petunjuk;

(e) keterangan terdakwa.

(2) Hal yang secara umum sudah diketahui tidak perlu dibuktikan.

4) Pasal 185

(1) Keterangan saksi sebagai alat bukti ialah apa yang saksi nyatakan di sidang pengadilan.

(2) Keterangan seorang saksi saja tidak cukup untuk membuktikan bahwa terdakwa bersalah terhadap perbuatan yang didakwakan kepadanya.

(3) Ketentuan sebagaimana dimaksud dalam ayat (2) tidak berlaku apabila disertai dengan suatu alat bukti yang sah lainnya.

(4) Keterangan beberapa saksi yang berdiri sendirisendiri tentang suatu kejadian atau keadaan dapat digunakan sebagai suatu alat bukti yang sah apabila keterangan saksi itu ada .hubungannya satu dengan yang lain sedemikian rupa, sehingga dapat membenarkan adanya suatu kejadian atau keadaan tertentu.

(5) Baik pendapat maupun rekàan, yang diperoleh dari hasil pemikiran saja, bukan merupakan keterangan saksi.

(6) Dalam menilai kebenaran keterangan seorang saksi, hakim harus dengan sungguh-sungguh memperhatikan: 
(a) persesuaian antara keterangan saksi satu dengan yang lain;

(b) persesuaian antara keterangan saksi dengan alat bukti lain;

(c) alasan yang mungkin dipergunakan oleh saksi untuk memberi keterangan yang tertentu;

(d) cara hidup dan kesusilaán saksi serta segala sesuatu yang pada umumnya dapat mempengaruhi dapat tidaknya keterangan itu dipercaya.

(7) Keterangan dari saksi yang tidak disumpah meskipun sesuai satu dengan yang lain tidak merupakan alat bukti namun apabila keterangan itu sesuai dengan keterangan dari saksi yang disumpah dapat dipergunakan sebagai tambahan alat bukti sah yanglain.

5) Pasal 186

Keterangan ahli ialah apa yang seorang ahli nyatakan di sidang pengadilan.

6) Pasal 187

Surat sebagaimana tersebut pada Pasal 184 ayat

(1) huruf c, dibuat atas sumpah jabatan atau dikuatkan dengan sumpah, adalah:

(1) berita acara dan surat lain dalam bentuk resmi yang dibuat oleh pejabat umum yang berwenang atau yang dibuat di hadapannya, yang memuat keterangan tentang kejadian atau keadaan yang didengar, dilihat atau yang dialaminya sendiri, disertai dengan alasan yang jelas dan tegas tentang keterangannya itu;

(2) surat yang dibuat menurut ketentuan peraturan perundang-undangan atau surat yang dibuat oleh pejabat mengenal hal yang termasuk dalam tata laksana yang menjadi tanggung jawabnya dan yang diperuntukkan bagi pembuktian sesuatu hal atau sesuatu keadaan; 
(3) surat keterangan dari seorang ahli yang memuat pendapat berdasarkan keahliannya mengenai sesuatu hal atau sesuatu keadaan yang diminta secara resmi dan padanya;

(4) surat lain yang hanya dapat berlaku jika ada hubungannya dengan isi dari alat pembuktian yang lain.

7) Pasal 188

(1) Petunjuk adalah perbuatan, kejadian atau keadaan, yang karena persesuaiannya, baik antara yang satu dengan yang lain, maupun dengan tindak pidana itu sendiri, menandakan bahwa telah terjadi suatu tindak pidana dan siapa pelakunya.

(2) Petunjuk sebagaimana dimaksud dalam ayat (1) hanya dapat diperoleh dari;

(a) keterangan saksi;

(b) surat;

(c) keterangan terdakwa.

(3) Penilaian atas kekuatan pembuktian dari suatu petunjuk dalam setiap keadaan tertentu dilakukan oleh hakim dengan arif lagi bijaksana, setelah ia mengadakan pemeriksaan dengan penuh kecermatan dan kesaksamaan berdasarkan hati nuraninya.

8) Pasal 189

(1) Keterangan terdakwa ialah apa yang terdakwa nyatakan di sidang tentang perbuatan yang ia lakukan atau yang ia ketahui sendiri atau alami sendiri.

(2) Keterangan terdakwa yang diberikan di luar sidang dapat digunakan untuk membantu menemukan bukti di sidang, asalkan keterangan itu didukung oleh suatu alat bukti yang sah sepanjang mengenai hal yang didakwakan kepadanya. 
(3) Keterangan terdakwa hanya dapat digunakan terhadap dirinya sendiri.

(4) Keterangan terdakwa saja tidak cukup untuk membuktikan bahwa ia bersalah melakukan perbuatan yang didakwakan kepadanya, melainkan harus disertal dengan alat bukti yang lain.

9) Pasal 190

(1) Selama pemeriksaan di sidang, jika terdakwa tidak ditahan, pengadilan dapat memerintahkan dengan surat penetapannya untuk menahan terdakwa apabila dipenuhi ketentuan Pasal 21 dan terdapat alasan cukup untuk itu.

(2) Dalam hal terdakwa ditahan, pengadilan dapat memerintahkan dengan surat penetapannya untuk membebaskan terdakwaa jika terdapat alasan cukup untuk itu dengan mengingat ketentuan Pasal 30.

10) Pasal 109

(1) Dalam hal penyidik telah mulai melakukan penyidikan suatu peristiwa yang merupakan tindak pidana, penyidik memberitahukan hal itu kepada penuntut umum.

(2) Dalam hal penyidik menghentikan penyidikan karena tidak terdapat cukup bukti atau peristiwa tersebut ternyata bukan merupakan tindak pidana atau penyidikan dihentikan demi hukum, maka penyidik memberitahukan hal itu kepada penuntut umum, tersangka atau keluarganya.

(3) Dalam hal penghentian tersebut pada ayat (2) dilakukan oleh penyidik sebagaimana dimaksud dalam Pasal 6 ayat

(1) huruf b, pemberitahuan mengenai hal itu segera disampaikan kepada penyidik dan penuntut umum.

11) Pasal 110

(1) Dalam hal penyidik telah selesai melakukan penyidikan, penyidik wajib segera menyerahkan berkas perkara itu kepada penuntut umum. 
(2) Dalam hal penuntut umum berpendapat bahwa hasil penyidikan tersebut ternyata masih kurang lengkap, penuntut umum segera mengembalikan berkas perkara itu kepada penyidik disertai petunjuk untuk dilengkapi.

(3) Dalam hal penuntut umum mengembalikan hasil penyidikan untuk dilengkapi, penyidik wajib segera melakukan penyidikan tambahan sesuai dengan petunjuk dari penuntut umum.

(4) Penyidikan dianggap telah selesai apabila dalam waktu empat belas hari penuntut umum tidak mengembalikan hasil penyidikan atau apabila sebelum batas waktu tersebut berakhir telah ada pemberitahuan tentang hal itu dari penuntut umum kepada penyidik.

b. Wewenang Penyidik KPK

1) Pasal 12 (Undang-Undang nomor 30 Tahun 2002)

2) Dalam melaksanakan tugas penyelidikan, penyidikan, dan penuntutan sebagaimana dimaksud dalam Pasal 6 huruf c, Komisi Pemberantasan Korupsi

berwenang :

(a) melakukan penyadapan dan merekam pembicaraan;

(b) memerintahkan kepada instansi yang terkait untuk melarang seseorang bepergian ke luar negeri;

(c) meminta keterangan kepada bank atau lembaga keuangan lainnya tentang keadaan keuangan tersangka atau terdakwa yang sedang diperiksa;

(d) memerintahkan kepada bank atau lembaga keuangan lainnya untuk memblokir rekening yang diduga hasil dari korupsi milik tersangka, terdakwa, atau pihak lain yang terkait;

(e) memerintahkan kepada pimpinan atau atasan tersangka untuk memberhentikan sementara tersangka dari jabatannya; 
(f) meminta data kekayaan dan data perpajakan tersangka atau terdakwa kepada instansi yang terkait;

(g) menghentikan sementara suatu transaksi keuangan, transaksi perdagangan, dan perjanjian lainnya atau pencabutan sementara perizinan, lisensi serta konsesi yang dilakukan atau dimiliki oleh tersangka atau terdakwa yang diduga berdasarkan bukti awal yang cukup ada hubungannya dengan tindak pidana korupsi yang sedang diperiksa;

(h) meminta bantuan Interpol Indonesia atau instansi penegak hukum negara lain untuk melakukan pencarian, penangkapan, dan penyitaan barang bukti di luar negeri;

(i) meminta bantuan kepolisian atau instansi lain yang terkait untuk melakukan penangkapan, penahanan, penggeledahan, dan penyitaan dalam perkara tindak pidana korupsi yang sedang ditangani.

3) Pasal 40

Komisi Pemberantasan Korupsi tidak berwenang mengeluarkan surat perintah penghentian penyidikan dan penuntutan dalam perkara tindak pidana korupsi.

4) Pasal 41

Komisi Pemberantasan Korupsi dapat melaksanakan kerja sama dalam penyelidikan, penyidikan, dan penuntutan tindak pidana korupsi dengan lembaga penegak hukum negara lain sesuai dengan peraturan perundang-undangan yang berlaku atau berdasarkan perjanjian internasional yang telah diakui oleh Pemerintah Republik Indonesia.

5) Pasal 42

Komisi Pemberantasan Korupsi berwenang mengkoordinasikan dan mengendalikan 
penyelidikan, penyidikan, dan penuntutan tindak pidana korupsi yang dilakukan bersama-sama oleh orang yang tunduk pada peradilan militer dan peradilan umum

\section{c. Hak-Hak Tersangka Tindak Pidana Korupsi}

1) Pasal 50

(a) Tersangka berhak segera mendapat pemeriksaan oleh penyidik dan selanjutnya dapat diajukan kepada penuntut umum.

(b) Tersangka berhak perkaranya segera dimajukan ke pengadilan oleh penuntut umum.

(c) Terdakwa berhak segera diadili oleh pengadilan.

2) Pasal 51

Untuk rnempersiapkan pembelaan:

(a) tersangka berhak untuk diberitahukan dengan jelas dalam bahasa yang dimengerti olehnya tentang apa yang disangkakan kepadanya pada waktu pemeriksaan dimulai,

(b) terdakwa berhak untuk diberitahukan dengan jelas dalam bahasa yang dimengerti olehnya tentang apa yang didakwakan kepadanya

3) Pasal 52

Dalam pemeriksaan pada tingkat penyidikan dan pengadilan, tersangka atau terdakwa berhak memberikan keterangan secara bebas kepada penyidik atau hakim

4) Pasal 53

(a) Dalam pemeriksaan pada tingkat penyidikan dan pengadilan, tersangka atau terdakwa berhak untuk setiap waktu mendapat bantuan juru bahasa sebagaimana dimaksud dalam Pasal 177.

(b) Dalam hal tersangka atau terdakwa bisu dan atau tuli diberlakukan ketentuan sebagainiana dimaksud dalam Pasal 178. 
5) Pasal 54

Guna kepentingan pembelaan, tersangka atau terdakwa berhak mendapat bantuan hukum dari seorang atau lebih penasihat hukum selama dalam waktu dan pada setiap tingkat pemeriksaan, menurut tatacara yang ditentukan dalam undangundang ini.

6) Pasal 55

Untuk mendapatkan penasihat hukum tersebut dalam Pasal 54, tersangka atau terdakwa berhak memiih sendiri penasihat hukumnya.

7) Pasal 56

(a) Dalam hal tersangka atau terdakwa disangka atau didakwa melakukan tindak pidana yang diancam dengan pidana mati atau ancaman pidana lima belas tahun atau lebih atau bagi mereka yang tidak mampu yang diancam dengan pidana lima tahun atau lebih yang tidak mempunyai penasihat hukum sendiri, pejabat yang bersangkutan pada semua tingkat pemeriksaan dalam proses peradilan wajib menunjuk penasihat hukum bagi mereka.

(b) Setiap penasihat hukum yang ditunjuk untuk bertindak sebagaimana dimaksud dalam ayat (1), memberikan bantuannya dengan cuma-cuma.

8) Pasal 57

(a) Tersangka atau terdakwa yang dikenakan penahanan berhak menghubungi penasihat hukumnya sesuai dengan ketentuan undangundang ini.

(b) Tersangka atau terdakwa yang berkebangsaan asing yang dikenakan penahanan berhak menghubungi dan berbicara dengan perwakilan negaranya dalam menghadapi proses perkaranya. 
9) Pasal 58

Tersangka atau terdakwa yang dikenakan penahanan berhak meng hubungi dan menerima kunjungan dokter pribadinya untuk kepentingan kesehatan baik yang ada hubungannya dengan proses perkara maupun tidak.

10) Pasal 59

Tersangka atau terdakwa yang dikenakan penahanan berhak diberitahukan tentang penahanan atas dirinya oleh pejabat yang berwenang pada semua tingkat pemeriksaan dalam proses peradilan, kepada keluarganya atau orang lain yang serumah dengan tersangka atau terdakwa ataupun orang lain yang bantuannya dibutuhkan oleh tersangka atau terdakwa untuk mendapatkan bantuan hukum atau jaminan bagi penangguhannya.

11) Pasal 60

Tersangka atau terdakwá berhak menghubungi dan menerima kunjungan dari pihak yang mempunyai hubungán kekeluargaan atau lainnya dengan tersangka atau terdakwa guna mendapatkan jaminan bagi penangguhan penahanan ataupun untuk usaha mendapatkan bantuan hukum.

12) Pasal 61

Tersangka atau terdakwa berhak secara langsung atau dengan perantaraan penasihat hukumnya menghubungi dan menerima kunjungan sanak keluarganya dalam hal yang tidak ada hubungannya dengan perkara tersangka atau terdakwa untuk kepentingan pekerjaan atau untuk kepentingan kekeluargaan.

13) Pasal 62

(a) Tersangka atau terdakwa berhak mengirim surat kepada penasihat hukumnya, dan menerima surat dari penasihat hukumnya dan sanak keluarga setiap kali yang diperlukan olehnya, untuk 
keperluan itu bagi tersangka atau terdakwa disediakan alat tulis menulis.

(b) Surat menyurat antara tersangka atau terdakwa dengan penasihat hukumnya atau sanak keluarganya tidak diperiksa oleh penyidik, penuntut umum, hakim atau pejabat rumah tahanan negara kecuali jika terdapat cukup alasan untuk diduga bahwa surat menyurat itu disalahgunakan.

(c) Dalam hal surat untuk tersangka atau terdakwa ditilik atau diperiksa oleh penyidik, penuntut umum, hakim atau pejabat rumah tahanan negara, hal itu diberitahukan kepada tersangka atau terdakwa dan surat tersebut dikirim kembali kepada pengirimnya setelah dibubuhi cap yang berbunyi "telah ditilik".

14) Pasal 63

Tersangka atau terdakwa berhak menghubungi dan menerima kunjungan dari rohaniwan.

15) Pasal 64

Terdakwa berhak untuk diadili di sidang pengadilan yang terbuka untuk umum.

16) Pasal 65

Tersangka atau terdakwa berhak untuk mengusahakan diri mengajukan saksi dan atau seseorang yang memiliki keahlian khusus guna memberikan keterangan yang menguntungkan bagi dirinya.

17) Pasal 66

Tersangka atau terdakwa tidak dibebani kewajiban pembuktian.

18) Pasal 67

Terdakwa atau penuntut umum berhak untuk minta banding terhadap putusan pengadilan tingkat pertama kecuali terhadap putusan bebas, lepas dari segala tuntutan hukum yang menyangkut masalah 
kurang tepatnya penerapan hukum dan putusan pengadilan dalam acara cepat.

19)Pasal 68

Tersangka atau terdakwa berhak menuntut ganti kerugian dan rehabilitasi sebagaimana diatur dalam Pasal 95.

\section{d. Prosedur Penuntutan}

1) Pasal 137 (KUHAP)

Penuntut umum berwenang melakukan penuntutan terhadap siapapun yang didakwa melakukan suatu tindak pidana dalam daerah hukumnya dengan melimpahkan perkara ke pengadilan yang berwenang mengadili.

2) Pasal 138

(a) Penuntut umum setelah menerima hasil penyidikan dan penyidik segera mempelajari dan menelitinya dan dalam waktu tujuh hari wajib memberitahukan kepada penyidik apakah hasil penyidikan itu sudah lengkap atau belum.

(b) Dalam hal hasil penyidikan ternyata belum lengkap, penuntut umum mengembalikan berkas perkara kepada penyidik disertai petunjuk tentang hal yang harus dilakukan untuk dilengkapi dan dalam waktu empat belas hari sejak tanggal penerimaan berkas, penyidik harus sudah menyampaikan kembali berkas perkara itu kepada penuntut umum.

3) Pasal 139

Setelah penuntut umum menerima atau menerima kembali hasil penyidikan yang lengkap dari penyidik, ia segera menentukan apakah berkas perkara itu sudah memenuhi persyaratan untuk dapat atau tidak dilimpahkan ke pengadilan. 
4) Pasal 140

(a) Dalam hal penuntut umum berpendapat bahwa dari hasil penyidikan dapat dilakukan penuntutan, ia dalam waktu secepatnya membuat surat dakwaan.

(b) ---

(c) Dalam hal penuntut umum memutuskan untuk menghentikan penuntutan karena tidak terdapat cukup bukti atau peristiwa tersebut ternyata bukan merupakan tindak pidana atau perkara ditutup demi hukum, penuntut umum menuangkan hal tersebut dalam surat ketetapan.

(d) Isi surat ketetapan tersebut diberitahukan kepada tersangka dan bila ia ditahan, wajib segera dibebaskan.

(e) Turunan surat ketetapan itu wajib disampaikan kepada tersangka atau keluarga atau penasihat hukum, pejabat rumah tahanan negara, penyidik dan hakim.

(f) Apabila kemudian ternyata ada alasan baru, penuntut umum dapat melakukan penuntutan terhadap tersangka

5) Pasal 141

Penuntut umum dapat melakukan penggabungan perkara dan membuatnya dalam satu surat dakwaan, apabila pada waktu yang sama atau hampir bersamaan ia menerima beberapa berkas perkara dalam hal:

(a) beberapa tindak pidana yang dilakukan oleh seorang yang sama dan kepentingan pemeriksaan tidak menjadikan halangan terhadap penggabungannya;

(b) beberapa tindak pidana yang bersangkut-paut satu dengan yang lain;

(c) beberapa tindak pidana yang tidak bersangkutpaut satu dengan yang lain, akan tetapi yang satu 
dengan yang lain itu ada hubungannya, yang dalam hal ini penggabungan tersebut perlu bagi kepentingan pemeriksaan.

6) Pasal 142

Dalam hal penuntut umum menerima satu berkas perkara yang memuat beberapa tindak pidana yang dilakukan oleh beberapa orang tersangka yang tidak termasuk dalam ketentuan Pasal 141, penuntut umum dapat melakukan penuntutan terhadap masing-masing terdakwa secara terpisah.

(a) Penuntut umum melimpahkan perkara ke pengadilan negeri dengan permintaan agar segera mengadii perkara tersebut disertai dengan surat dakwaan.

(b) Penuntut umum membuat surat dakwaan yang diberi tanggal dan ditandatangani serta berisi:

(1) nama lengkap, tempat lahir, umur atau tanggal lahir, jenis kelamin, kebangsaan, tempat tinggal, agama dan pekerjaan tersangka;

(2) uraian secara cermat, jelas dan lengkap mengenai tindak pidana yang didakwakan dengan menyebutkan waktu dan termpat tindak pidana itu dilakukan.

(c) Surat dakwaan yang tidak memenuhi ketentuan sebagaimana dimaksud dalam ayat (2) huruf $b$ batal demi hukum.

(d) Turunan surat pelimpahan perkara beserta surat dakwaan disampaikan kepada tersangka atau kuasanya atau penasihat hukumnya dan penyidik, pada saat yang bersamaan. dengan penyampaian surat pelimpahan perkara tersebut ke pengadilan negeri. 


\section{e. Penuntutan oleh KPK}

7) Pasal 51

(1) Penuntut adalah Penuntut Umum pada Komisi Pemberantasan Korupsi yang diangkat dan diberhentikan oleh Komisi Pemberantasan Korupsi.

(2) Penuntut Umum sebagaimana dimaksud pada ayat (1) melaksanakan fungsi penuntutan tindak pidana korupsi.

(3) Penuntut sebagaimana dimaksud pada ayat (1) adalah Jaksa Penuntut Umum.

8) Pasal 52

(1) Penuntut Umum, setelah menerima berkas perkara dari penyidik, paling lambat 14 (empat belas) hari kerja terhitung sejak tanggal diterimanya berkas tersebut, wajib melimpahkan berkas perkara tersebut kepada Pengadilan Negeri.

(2) Dalam hal sebagaimana dimaksud pada ayat (1), Ketua Pengadilan Negeri wajib menerima pelimpahan berkas perkara dari Komisi Pemberantasan Korupsi untuk diperiksa dan diputus.

\section{a. Pemeriksaan di Sidang Pengadilan}

\section{1) Prosedur Panggilan}

9) Pasal 145

(1) Pemberitahuan untuk datang ke sidang pengadilan dilakukan Secara sah, apabila disampaikan dengan surat panggilan kepada terdakwa di alamat tempat tinggalnya atau apabila tempat tinggalnya tidak diketahui, disampaikan di tempat kediaman terakhir.

(2) Apabila terdakwa tidak ada di tempat tinggalnya atau ditempat kediaman terakhir, surat panggilan disampaikan melalui kepala desa yang berdaerah hukum tempat tinggal terdakwa atau tempat kediaman terakhir.

(3) Dalam hal terdakwa ada dalam tahanan surat panggilan disampaikan kepadanya melalui pejabat rumah tahanan negara.

(4) Penerimaan surat panggilan oleh terdakwa sendiri ataupun oleh orarig lain atau melalui orang lain, dilakukan dengan tanda penerimaan. 
(5) Apabila tempat tinggal maupun tempat kediaman terakhir tidak dikenal, surat panggilan ditempelkan pada tempat pengumuman di gedung pengadilan yang berwenang mengadili perkaranya.

10) Pasal 146

(1) Penuntut umum menyampaikan surat panggilan kepada terdakwa yang memuat tanggal, hari, serta jam sidang dan untuk perkara apa ia dipanggil yang harus sudah diterima oleh yang bersangkutan selambat-lambatnya tiga hari sebelum sidang dimulai.

(2) Penuntut umum menyampaikan surat panggilan kepada saksi yang memuat tanggal, hari serta jam sidang dan untuk perkara apa ia dipanggil yang harus sudah diterima oleh yang bersangkutan selambat-Iambatnya tiga hari sebelum sidang dimulai.

\section{2) Proses Pemeriksaan di Depan Sidang Pengadilan Negeri}

11) Pasal 5 (Undang-Undang Nomor 46 Tahun 2009)

Pengadilan Tindak Pidana Korupsi merupakan satusatunya pengadilan yang berwenang memeriksa, mengadili, dan memutus perkara tindak pidana korupsi.

12) Pasal 6

Pengadilan Tindak Pidana Korupsi sebagaimana dimaksud dalam Pasal 5 berwenang memeriksa, mengadili, dan memutus perkara:

a. tindak pidana korupsi;

b. tindak pidana pencucian uang yang tindak pidana asalnya adalah tindak pidana korupsi; dan/atau

c. tindak pidana yang secara tegas dalam undang-undang lain ditentukan sebagai tindak pidana korupsi.

13) Pasal 7

Pengadilan Tindak Pidana Korupsi pada Pengadilan Negeri Jakarta Pusat juga berwenang memeriksa, mengadili, dan memutus perkara tindak pidana korupsi sebagaimana dimaksud dalam Pasal 6 yang dilakukan oleh warga negara Indonesia di luar wilayah negara Republik Indonesia. 


\section{3) Kewenangan Hakim}

\section{4) Pasal 10}

(1) Dalam memeriksa, mengadili, dan memutus perkara tindak pidana korupsi, Pengadilan Tindak Pidana Korupsi, pengadilan tinggi, dan Mahkamah Agung terdiri atas Hakim Karier dan Hakim ad hoc.

(2) Hakim Karier sebagaimana dimaksud pada ayat (1) ditetapkan berdasarkan keputusan Ketua Mahkamah Agung. (3) Hakim Karier yang ditetapkan sebagaimana dimaksud pada ayat (1) selama menangani perkara tindak pidana korupsi dibebaskan dari tugasnya untuk memeriksa, mengadili, dan memutus perkara lain.

(4) Hakim ad hoc pada Pengadilan Tindak Pidana Korupsi, pengadilan tinggi, dan pada Mahkamah Agung sebagaimana dimaksud pada ayat (1) diangkat dan diberhentikan oleh Presiden atas usul Ketua Mahkamah Agung.

(5) Hakim ad hoc sebagaimana dimaksud pada ayat (4) diangkat untuk masa jabatan selama 5 (lima) tahun dan dapat diangkat kembali untuk 1 (satu) kali masa jabatan.

15) Pasal 25

Pemeriksaan di sidang Pengadilan Tindak Pidana Korupsi dilakukan berdasarkan hukum acara pidana yang berlaku, kecuali ditentukan lain dalam Undang-Undang ini.

16) Pasal 26

(1) Dalam memeriksa, mengadili, dan memutus perkara tindak pidana korupsi dilakukan dengan majelis hakim berjumlah ganjil sekurang-kurangnya 3 (tiga) orang hakim dan sebanyak- banyaknya 5 (lima) orang hakim, terdiri dari Hakim Karier dan Hakim ad hoc.

(2) Dalam hal majelis hakim sebagaimana dimaksud pada ayat

(1) berjumlah 5 (lima) orang hakim, maka komposisi majelis hakim adalah 3 (tiga) banding 2 (dua) dan dalam hal majelis hakim berjumlah 3 (tiga) orang hakim, maka komposisi majelis hakim adalah 2 (dua) banding 1 (satu).

(3) Penentuan mengenai jumlah dan komposisi majelis hakim sebagaimana dimaksud pada ayat (1) dan ayat (2) ditetapkan 
oleh ketua pengadilan masing-masing atau Ketua Mahkamah Agung sesuai dengan tingkatan dan kepentingan pemeriksaan perkara kasus demi kasus.

(4) Ketentuan mengenai kriteria dalam penentuan jumlah dan komposisi majelis hakim dalam memeriksa, mengadili, dan memutus perkara tindak pidana korupsi sebagaimana dimaksud pada ayat (3) diatur dengan Peraturan Mahkamah Agung

17) Pasal 28

(1) Semua alat bukti yang diajukan di dalam persidangan, termasuk alat bukti yang diperoleh dari hasil penyadapan, harus diperoleh secara sah berdasarkan ketentuan peraturan perundang-undangan.

(2) Hakim menentukan sah tidaknya alat bukti yang diajukan di muka persidangan baik yang diajukan oleh penuntut umum maupun oleh terdakwa.

18) Pasal 29

Perkara tindak pidana korupsi diperiksa, diadili, dan diputus oleh Pengadilan Tindak Pidana Korupsi tingkat pertama dalam waktu paling lama 120 (seratus dua puluh) hari kerja terhitung sejak tanggal perkara dilimpahkan ke Pengadilan Tindak Pidana Korupsi.

19) Pasal 30

Pemeriksaan tingkat banding Tindak Pidana Korupsi diperiksa dan diputus dalam waktu paling lama 60 (enam puluh) hari kerja terhitung sejak tanggal berkas perkara diterima oleh Pengadilan Tinggi.

20) Pasal 31

Pemeriksaan tingkat kasasi Tindak Pidana Korupsi diperiksa dan diputus dalam waktu paling lama 120 (seratus dua puluh) hari kerja terhitung sejak tanggal berkas perkara diterima oleh Mahkamah Agung.

21) Pasal 32

Dalam hal putusan pengadilan dimintakan peninjauan kembali, pemeriksaan perkara tindak pidana korupsi diperiksa dan diputus dalam waktu paling lama 60 (enam puluh) hari 
kerja terhitung sejak tanggal berkas perkara diterima oleh Mahkamah Agung.

22) Pasal 34

Pada saat Undang-Undang ini mulai berlaku:

a. perkara tindak pidana korupsi yang sedang diperiksa oleh Pengadilan Tindak Pidana Korupsi pada Pengadilan Negeri Jakarta Pusat yang dibentuk berdasarkan Undang-Undang Nomor 30 Tahun 2002 tentang Komisi Pemberantasan Tindak Pidana Korupsi atau yang sedang diperiksa pada setiap tingkat pemeriksaan, tetap diperiksa dan diadili sampai perkara tindak pidana korupsi tersebut diputus sesuai dengan peraturan perundang-undangan;

b. perkara tindak pidana korupsi yang sedang diperiksa oleh pengadilan negeri atau yang sedang diperiksa pada setiap tingkat pemeriksaan, tetap diperiksa dan diadili sampai perkara tindak pidana korupsi tersebut diputus sesuai dengan peraturan perundang-undangan.

23) Pasal 35

(1) Dengan Undang-Undang ini untuk pertama kali Pengadilan Tindak Pidana Korupsi dibentuk pada setiap pengadilan negeri di ibu kota provinsi.

Dengan demikian berdasarkan uraian di atas maka perlu bagi setiap elemen penegak hukum dalam tindak pidana korupsi agar perlu dimaksimalkan perannya sehingga tindak pidana korupsi dapat dicegah dan ditangani secara baik, optimal, sistematis dan terkendali di Negara Kesatuan Republik Indonesia. 


\section{BAB VI \\ GAMBARAN UMUM \\ PENYELENGGARAAN \\ PEMERINTAHAN}

Secara formal pemerintahan Kabupaten Buru ditetapkan sebagai kabupaten administratif terlepas dari Kabupaten Maluku Tengah Provinsi Maluku pada tahun 1999 pada masa kepemimpinan Presiden Abdurrahman Wahid melalui UndangUndang Nomor 46 Tahun 1999 tentang Pembentukan Provinsi Maluku Utara, Kabupaten Buru dan Kabupaten Maluku Tenggara Barat (Lembaran Negara Republik Indonesia Tahun 1999 Nomor 174, Tambahan Lembaran Negara Republik Indonesia Nomor 3895), sebagaimana telah diubah dengan Undang-undang Nomor 6 Tahun 2000 tentang Perubahan Atas Undang-undang Nomor 46 Tahun 1999 tentang Pembentukan Provinsi Maluku Utara., Kabupaten Buru dan Kabupaten Maluku Tenggara Barat (Lembaran Negara Repubiik Indonesia Tahun 2000 Nomor 23, Tambahan Lembaran Negara Republik Indonesia Nomor 3961).

\section{A. Sejarah Singkat Kabupaten Buru}

Pada Perang Dunia II, Di zaman pendudukan jepang, wilayah Buru memiliki posisi penting dalam pertahanan dan keamanan. Hal ini dikarenakan Namlea yang merupakan salah satu wilayah di Buru menjadi pangkalan transit pesawatpesawat tempur Jepang yang terlibat perang dengan pasukan sekutu. Seiring dengan kemerdekaan Indonesia dan berdirinya pemerinthan RI, pada tahun 1945, provinsi Maluku juga dibentuk, Wilayah Buru memiliki luas sebesar $12.345 \mathrm{~km}^{2}$, terdiri dari satu pulau besar yaitu pulau Buru dan beberapa pulau kecil yaitu Pulau Ambalau, Puau Pasir Putih, Pulau Fogi, Pulau Tomahu, dan Pulau Oki. Semula wilayah ini memiliki dua kecamatan saja, yakni kecamatan Buru Utara dengan 
Ibukota Namlea dan Kecamatan Buru Selatan dengan Ibukota Leksula. ${ }^{89}$

Pada awal orde baru, Wilayah Buru ditetapkan sebagai Camp tahanan politik. Sebayak 12.000 orang tapol PKI pada tahun 1969 diberangkatkan dengan kapal laut ke Pulau Buru, di tanah buru mereka bekerja megelolah tanah bekas hutan yang penuh pepohonan. Sejak tahun 1950-an, kawasan camp itu sudah direncanakan sebagai daerah transmigrasi karena tanahnya cocok untuk daerah pertanian. ${ }^{90}$ Sejalan dengan bergulirnya reformasi yang membawa angin perubahan dalam tatanan kehidupan bangsa Indonesia, masyarakat masyarakat burupun menuntut diadakannya perubahan. Mereka menuntut pemekaran wilayah Buru menjadi kabupaten Buru. Meski persiapan infrastruktur dan SDM masih jauh dari yang diharapkan, namun tuntutan pemekaran wilayah ini tetap kukuh. Dengan diberlakukannya UndangUndang No. 22 Tahun 1999 tentang Pemerintahan Daerah dan diberikannya kekuasaan untuk mengatur dan mengurus rumah tangganya tersendiri. Maka masyarakat buru dengan dukungan pemerintah Provinsi Maluku dan berbagai pihak lainnya, mendapatkan pengakuan sebagai kabupaten, barulah pada tanggal 12 Oktober 1999, Kabupaten buru secara resmi terbentuk. ${ }^{91}$

Kabupaten Buru pada saat terbentuk terdiri dari tiga kecamatan yaitu Kecamatan Buru Utara, Kecamatan Buru selatan dan Kecamatan Buru Utara Barat. Namun secara adat, di wilayah kabupaten Buru sendiri juga terbagi dalam 8 wilayah pertuanan yaitu Kayeli, Lilialy, Tagalisa, Lisela, Masarete, Fogi, Wisama dan Ambalau. Tiap petuanan ini dipimpina oleh seorang raja.

Pada awal pemerintahan kabupaten Buru dipimpin oleh R. S. Sangadji yang merupakan penjabat sementara Bupati dari tahun 1999 sampai tahun 2001, pada tahun tahun 2001

sampai

89 Badan Pusat Statistik Kabupaten Buru (BPS), Buru Dalam Angka Tahun 20013, hal. ii

90 Ibid., hal. iii

91 Ibid. 
dengan 2011 dipimpin oleh Drs. Husnie Hentihu sebagai Bupati defenitif, kemudian tahun 2012 hingga saat ini Bupati kabupaten Buru dipimpin oleh Ramly Umasugi, S,Pi, MM.

\section{B. Kondisi Geografi Wilayah Administratif Pemerintahan}

\section{Letak Geografis}

Pulau Buru (9.599 Km2), yang memiliki panjang $(140 \mathrm{~km})$ dan lebar $(90 \mathrm{~km})$ dengan puncak bukit/gunung tertingginya adalah Kan Palatmada (2.429 m). Terdapat 3 (tiga) blok pegunungan yang masing-masing dipisahkan oleh struktur kelurusan lembah. Pada bagian barat tapak Kan Palatmada dengan ketinggian diatas $2000 \mathrm{~m}$, dimana dibatasi oleh lembah depresi Sungai Nibe-Danau Rana dan Sungai Wala. Pada blok tengah dengan ketinggian diatas $1000 \mathrm{~m}$ yang dibentuk oleh Teluk Kayeli dan Lembah Apu, sedangkan blok selatan dibentuk oleh Lembah Kalua dengan Gunung Batabual (1.731 m). Kabupaten Buru terletak antara $2^{\circ} 25^{\text {ec }}-3^{\circ} 55^{\text {ce }}$ Lintang Selatan dan $125^{\circ} 70^{\text {ee }}-127^{\circ} 21^{\text {ec }}$ Bujur Timur. ${ }^{92}$

\section{Luas Wilayah Administratif}

Kabupaten Buru sebelum pemekaran Buru Selatan memiliki luas wilayah $12.655,58 \mathrm{Km} 2$ dengan 10 (sepuluh) kecamatan (Namlea, Waeapo, Airbuaya, Waplau, Batabual, Lolong Guba, Waelata, Fena Leisela, Teluk Kaiely, Lilialy ) dan 106 (seratus enam) desa. Setelah pemekaran Buru Selatan pada tahun 2008, luas wilayah Kabupaten Buru menjadi 7.595,58 $\mathrm{Km}^{2}(69,42 \%$ luas pulau buru), dengan batas-batas wilayah sebagai berikut :

a. Sebelah Utara berbatasan dengan Laut Seram

b. Sebelah Selatan berbatasan dengan Kabupaten Buru Selatan

c. Sebelah Barat berbatasan dengan Laut Buru

d. Sebelah Timur berbatasan dengan Selat Manipa. ${ }^{93}$

92 Ibid., hal. 1

93 Ibid 


\section{Satuan Kerja Perangkat Daerah (SKPD) Pada Lingkup Pemerintahan}

Tabel 1 SKPD Pada Lingkup Pemda Buru

\begin{tabular}{|c|c|c|c|}
\hline No & 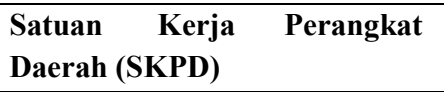 & $\begin{array}{ll}\text { Perda } & \text { Pembantukan } \\
\text { SKPD } & \\
\end{array}$ & Ket \\
\hline 1 & Inspektorat & Perda No. 22 / 2008 & \\
\hline 2. & Sekretariat DPRD & $\begin{array}{l}\text { Perda No. } 01 / 2008 \\
\text { Diubah dengan Perda } \\
\text { No. } 05 / 2012\end{array}$ & \\
\hline 3 & Badan Kepegawaian Daerah & Perda No. $18 / 2008$ & \\
\hline 4 & Badan Ketahanan Pangan & Perda No. $11 / 2012$ & \\
\hline 5 & Badan Kesbangpol & $\begin{array}{l}\text { Perda No. } 20 / 2008 \\
\text { diubah dengan } \\
\text { No. } 02 / 2013\end{array}$ & \\
\hline 6 & $\begin{array}{l}\text { Badan Perencanaan } \\
\text { Pembangunan Daerah }\end{array}$ & $\begin{array}{l}\text { Perda No. } 17 / 2008 \\
\text { diubah dengan Perda } \\
\text { No. } 01 / 2013\end{array}$ & \\
\hline 7 & $\begin{array}{l}\text { Badan Penanggulangan } \\
\text { Bencana Daerah }\end{array}$ & Perda No. $01 / 2010$ & \\
\hline 8 & $\begin{array}{l}\text { Badan Pemberdayaan } \\
\text { Masyarakat Desa }\end{array}$ & Perda No. 19 / 2008 & \\
\hline 9 & Badan Lingkungan Hidup & Perda No. 13 / 2012 & \\
\hline 10 & $\begin{array}{l}\text { Badan Pengelolaan Keuangan } \\
\text { dan Kekayaan Daerah }\end{array}$ & Perda No. 10 / 2012 & \\
\hline 11 & $\begin{array}{l}\text { Dinas Kependudukan, Capil } \\
\text { \& KB }\end{array}$ & $\begin{array}{l}\text { Perda No. } 08 / 2008 \\
\text { diubah dengan } \\
\text { No. } 01 / 2010\end{array}$ & \\
\hline 12 & Dinas Pertanian & Perda No. 07 / 2012 & \\
\hline 13 & Dinas Perindag & Perda No. $05 / 2008$ & \\
\hline 14 & Dinas Koperasi dan UKM & Perda No. 06 / 2008 & \\
\hline 15 & $\begin{array}{l}\text { Dinas Tenaga Kerja dan } \\
\text { Transmigrasi }\end{array}$ & Perda No. 07 / 2008 & \\
\hline 16 & $\begin{array}{l}\text { Dinas Pendidikan dan } \\
\text { Kebudayaan }\end{array}$ & Perda No. 03 / 2008 & \\
\hline 17 & Dinas Sosial & Perda No. 010 / 2008 & \\
\hline 18 & $\begin{array}{l}\text { Dinas Tata Kota Kebersihan } \\
\text { dan Pemadam Kebakaran }\end{array}$ & $\begin{array}{ll}\text { Perda No. } & 12 / 2008 \\
\text { diubah dengan } & \text { Perda } \\
\text { No. } 08 / 2012\end{array}$ & \\
\hline
\end{tabular}




\begin{tabular}{|c|c|c|}
\hline 19 & Dinas Pendapatan & Perda No. 06 / 2012 \\
\hline 20 & $\begin{array}{l}\text { Dinas Pertambangan dan } \\
\text { ESDM }\end{array}$ & \\
\hline 21 & Dinas Kesehatan & Perda No. $02 / 2008$ \\
\hline 22 & Dinas Kehutanan & Perda No. $16 / 2008$ \\
\hline 23 & Dinas Pekerjaan Umum & Perda No. $11 / 2008$ \\
\hline 24 & $\begin{array}{lll}\text { Dinas } & \text { Kelautan } & \text { dan } \\
\text { Perikanan } & & \\
\end{array}$ & Perda No. $15 / 2008$ \\
\hline 25 & $\begin{array}{l}\text { Dinas Perhubungan dan } \\
\text { Pariwisata }\end{array}$ & Perda No. 09 / 2008 \\
\hline 26 & Kantor Satpol PP & $\begin{array}{l}\text { Perda No. } 23 / 2008 \\
\text { diubah dengan } \\
\text { No. } 03 / 2013\end{array}$ \\
\hline 27 & $\begin{array}{l}\text { Kantor Pelayanan Perizinan } \\
\text { dan Penanaman Modal }\end{array}$ & Perda No. 12 / 2012 \\
\hline 28 & Kantor Perpustakaan Daerah & Perda No. 24 / 2008 \\
\hline 29 & Rumah Sakit Umum Daerah & Perda No. $25 / 2008$ \\
\hline 30 & Sekretariat KORPRI & Perda No. $02 / 2010$ \\
\hline 31 & Bagian Hukum & $\begin{array}{l}\text { Perda No. } 01 / 2008 \\
\text { Diubah dengan Perda } \\
\text { No. 05/2012 }\end{array}$ \\
\hline 32 & Bagian Humas \& Protokol & $\begin{array}{l}\text { Perda No. } 01 / 2008 \\
\text { Diubah dengan Perda } \\
\text { No. 05/2012 }\end{array}$ \\
\hline 33 & Bagian Tata Pemerintahan & $\begin{array}{l}\text { Perda No. } 01 / 2008 \\
\text { Diubah dengan Perda } \\
\text { No. 05/2012 }\end{array}$ \\
\hline 34 & Bagain Ortala & $\begin{array}{l}\text { Perda No. } 01 / 2008 \\
\text { Diubah dengan Perda } \\
\text { No. } 05 / 2012\end{array}$ \\
\hline 35 & Bagian Umum & $\begin{array}{l}\text { Perda No. } 01 / 2008 \\
\text { Diubah dengan Perda } \\
\text { No. } 05 / 2012\end{array}$ \\
\hline 36 & $\begin{array}{l}\text { Bagian Ekonomi \& } \\
\text { Pembangunan }\end{array}$ & $\begin{array}{l}\text { Perda No. } 01 / 2008 \\
\text { Diubah dengan Perda } \\
\text { No. 05/2012 }\end{array}$ \\
\hline 37 & Bagian Pemerintahan Desa & $\begin{array}{l}\text { Perda No. } 01 / 2008 \\
\text { Diubah dengan Perda } \\
\text { No. } 05 / 2012\end{array}$ \\
\hline
\end{tabular}




\begin{tabular}{|c|c|c|}
\hline 38 & Bagian Kesejahteraan Rakyat & $\begin{array}{l}\text { Perda No. } 01 / 2008 \\
\text { Diubah dengan Perda } \\
\text { No. 05/2012 }\end{array}$ \\
\hline 39 & $\begin{array}{ll}\text { Bagian } & \text { Pemberdayaan } \\
\text { Perempuan } & \end{array}$ & $\begin{array}{l}\text { Perda No. } 01 / 2008 \\
\text { Diubah dengan Perda } \\
\text { No. 05/2012 }\end{array}$ \\
\hline 40 & Kantor Kecamatan & Perda No. $26 / 2008$ \\
\hline 41 & $\begin{array}{l}\text { Kantor Kecamatan Lolong } \\
\text { Guba }\end{array}$ & Perda No. 20 / 2012 \\
\hline 42 & Kantor Kecamatan Waelata & Perda No. $21 / 2012$ \\
\hline 43 & $\begin{array}{lll}\text { Kantor } & \text { Kecamatan } & \text { Fena } \\
\text { Leisela } & & \\
\end{array}$ & Perda No. $22 / 2012$ \\
\hline 44 & $\begin{array}{lll}\text { Kantor } & \text { Kecamatan } & \text { Teluk } \\
\text { Kaiely } & & \end{array}$ & Perda No. 23 / 2012 \\
\hline 45 & Kantor Kecamatan Lilialy & Perda No. 24 / 2012 \\
\hline
\end{tabular}

Sumber Data: Bagian Hukum Setda Kabupaten Buru 2014

\section{Kondisional Aparatur Sipil Negara Pada Pemda}

Secara keseluruhan jumlah pegawai negeri sipil yang bekerja menunjang penyelenggaraan pemerintahan daerah pada kabupaten buru berjum 4.193 pegawai ditambah dengan 618 pegawai honorer yang dipekerjakan guna melengkapi kekurangan tenaga pegawai di kabupaten buru. Olehnya itu perlu dijelaskan kondisi aparatur sipil daerah di kabupaten Buru sehingga dapat dianalisa lebih lanjut tentang potensi pengelolaan APBD di kabupaten buru.

Kondisi Aparatur Sipil Negara pada lingkup pemerintahan daerah kabupaten buru dapat dijelaskan sebagai berikut: 
1. Jumlah Pegawai Negeri Sipil (PNS) Pemda Kabupaten Buru Menurut Tingkat Pendidikan yang Ditamatkan dan Jenis Kelamin, 201294

Tabel. 2

Jumlah PNS Menurut Tingkat

Pendidikan dan Jenis Kelamin

\begin{tabular}{|l|l|l|l|}
\hline $\begin{array}{l}\text { Tingkat } \\
\text { Pendidikan } \\
\text { yang } \\
\text { Ditamatkan }\end{array}$ & Laki-laki & Perempuan & Jumlah \\
\hline $\mathbf{( 1 )}$ & $\mathbf{( 2 )}$ & $\mathbf{( 3 )}$ & $\mathbf{( 4 )}$ \\
\hline SD & 13 & 1 & 14 \\
\hline SLTP & 30 & 8 & 38 \\
\hline SLTA & 647 & 596 & 1.243 \\
\hline DIPLOMA & 412 & 800 & 1.212 \\
\hline S1 & 903 & 713 & 1.616 \\
\hline S2 & 55 & 15 & 70 \\
\hline S3 & 0 & 0 & 0 \\
\hline Buru & $\mathbf{2 0 6 0}$ & $\mathbf{2 1 3 3}$ & $\mathbf{4 . 1 9 3}$ \\
\hline
\end{tabular}

Sumber Data : Badan Kepegawaian Daerah Kab. Buru 2012

Dari Tabel 2 dapat terlihat bahwa jumlah pegawai yang memiliki tingkat pendidikan S1 dan S2 berjumlah 1.686 PNS sedang jenjang pendidikan dibawah jenjang pendidikan S1 (DIPLOMA, SLTA, SLTP dan SD) adalah berjumlah 2.507 PNS, sehingga persentase pegawai dalam mengelola APBD di kabupaten buru masi dianggap perlu peningkatan tingkat pendidikannya. 
2. Jumlah Pegawai Negeri Sipil (PNS) Pemda Kabupaten Buru Menurut Golongan Dan jenis Kelamin 95

Tabel. 3

Jumlah PNS Menurut Gol. Dan Jenis Kelamin

\begin{tabular}{|l|l|l|l|}
\hline Golongan & Laki-laki & Perempuan & Jumlah \\
\hline (1) & $\mathbf{( 2 )}$ & $\mathbf{( 3 )}$ & $\mathbf{( 4 )}$ \\
\hline I & 24 & 4 & 28 \\
\hline II & 845 & 1.205 & 2.050 \\
\hline III & 976 & 832 & 1.808 \\
\hline IV & 215 & 92 & 307 \\
\hline Buru & $\mathbf{2 . 0 6 0}$ & $\mathbf{2 . 1 3 3}$ & $\mathbf{4 . 1 9 3}$ \\
\hline
\end{tabular}

Sumber Data : Badan Kepegawaian Daerah Kab. Buru 2012

3. Jumlah Pegawai Negeri Sipil (PNS) Pemda Kabupaten Buru Menurut Eselon Dan jenis Kelamin ${ }^{96}$

Tabel. 4

Jumlah PNS Menurut Eselon Dan Jenis Kelamin

\begin{tabular}{|l|l|l|l|}
\hline Eselon & Laki-laki & Perempuan & Jumlah \\
\hline (1) & $\mathbf{( 2 )}$ & $\mathbf{( 3 )}$ & $\mathbf{( 4 )}$ \\
\hline II & 13 & 0 & 13 \\
\hline III & 93 & 22 & 115 \\
\hline IV & 147 & 81 & 228 \\
\hline Buru & $\mathbf{2 5 3}$ & $\mathbf{1 0 3}$ & $\mathbf{3 5 6}$ \\
\hline
\end{tabular}

Sumber Data: Badan Kepegawaian Daerah Kab. Buru 2012

Dengan demikian maka terlihat bahwa dari jumlah 4.193 PNS di kabupaten Buru hanya 356 PNS yang menduduki jabatan eselonisasi. 


\section{Jumlah Pegawai Negeri Sipil (PNS) Pemda Kabupaten Buru Menurut Dinas/Instansi Pemerintah Dan Golongan ${ }^{97}$}

\section{Tabel. 5}

Jumlah PNS Menurut Dinas/Instansi Pemerintah dan Gol.

\begin{tabular}{|c|c|c|c|c|c|c|}
\hline \multirow{2}{*}{\multicolumn{2}{|c|}{ Dinas / Instansi Pemerintah }} & \multicolumn{5}{|c|}{ Golongan PNS } \\
\hline & & \multirow{3}{*}{$\begin{array}{l}I \\
\text { (2) }\end{array}$} & \multirow{3}{*}{\begin{tabular}{|l} 
II \\
$(3)$
\end{tabular}} & \multirow{3}{*}{$\begin{array}{l}\text { III } \\
\text { (4) }\end{array}$} & \multirow{3}{*}{$\begin{array}{l}\text { IV } \\
\mathbf{( 5 )} \\
9\end{array}$} & \multirow{3}{*}{$\begin{array}{l}\text { Jml } \\
\text { (6) } \\
9\end{array}$} \\
\hline (1) & & & & & & \\
\hline 1 & Sekretariat Daerah & & & & & \\
\hline 2 & Bagian Tata Pemerintahan & & 1 & 4 & 1 & 6 \\
\hline 3 & Bagian Pemerintahan Desa & & & 5 & & 5 \\
\hline 4 & Bagian Kesejahteraan Rakyat & & 6 & 4 & & 10 \\
\hline 5 & Bagian Ekonomi Pembangunan & & 8 & 11 & 1 & 20 \\
\hline 6 & Bagian Humas \& Protokoler & & 8 & 5 & & 13 \\
\hline 7 & Bagian Pemberdayaan Perempuan & & 1 & 5 & & 6 \\
\hline 8 & Bagian Hukum & & 4 & 4 & & 8 \\
\hline 9 & Bagian Organisasi & & 8 & 3 & 1 & 12 \\
\hline 10 & Bagian Umum Perlengkapan & 4 & 28 & 12 & & 44 \\
\hline 11 & Sekretariat DPRD & 2 & 28 & 19 & 3 & 52 \\
\hline 12 & Dinas Kesehatan & 1 & 30 & 38 & 2 & 71 \\
\hline 13 & Dinas Pendidikan Kebudayaan & 8 & 982 & 957 & 215 & 2162 \\
\hline 14 & Dinas Pendapatan & 1 & 24 & 17 & 1 & 43 \\
\hline 15 & $\begin{array}{|ll|}\text { Dinas } & \text { Perindustrian } \\
\text { Perdagangan }\end{array}$ & & 21 & 24 & 1 & 46 \\
\hline 16 & Dinas Koperasi \& UKM & & & & & \\
\hline 17 & Disnakertrans & 3 & 21 & 21 & 2 & 47 \\
\hline 18 & $\begin{array}{l}\text { Dinas Kependudukan Paencatatan } \\
\text { Sipil }\end{array}$ & & 7 & 20 & 1 & 28 \\
\hline 19 & Dinas Perhubungan & & 19 & 17 & 1 & 37 \\
\hline 20 & Dinas Sosial & & 9 & 24 & 1 & 34 \\
\hline 21 & Dinas Pekerjaan Umum & & 39 & 41 & 2 & 82 \\
\hline 22 & $\begin{array}{l}\text { Dinas Tata Kota, Kebersihan \& } \\
\text { Pemadam Kebakaran }\end{array}$ & & 21 & 27 & & 48 \\
\hline 23 & Dinas Pertanian & & 61 & 77 & 2 & 140 \\
\hline 24 & Dinas Kelauatan Dan Perikanan & 1 & 18 & 26 & 2 & 47 \\
\hline 25 & Dinas Kehutanan & & 41 & 46 & 3 & 90 \\
\hline 26 & Dinas Pertambangan dan ESDM & & 5 & 15 & & 20 \\
\hline 27 & BAPPEDA & 1 & 13 & 35 & 3 & 52 \\
\hline 28 & $\begin{array}{l}\text { BP. Keuangan dan Kekayaan } \\
\text { Daerah }\end{array}$ & & 37 & 35 & 2 & 74 \\
\hline 29 & Badan Kepegawaian Daerah & & 20 & 24 & 1 & 45 \\
\hline 30 & BPMD & & 19 & 16 & 2 & 37 \\
\hline
\end{tabular}




\begin{tabular}{|c|c|c|c|c|c|c|}
\hline 31 & Badan Kesbang Linmas Politik & & 20 & 7 & 2 & 29 \\
\hline 32 & $\begin{array}{l}\text { Badan Penanggulangan Bencana } \\
\text { Daerah }\end{array}$ & & 4 & 13 & 1 & 18 \\
\hline \multicolumn{7}{|l|}{33} \\
\hline 34 & $\begin{array}{l}\text { Badan Ketahanan Pangan \& } \\
\text { Penyulhan }\end{array}$ & & 5 & 20 & 2 & 27 \\
\hline 35 & Inspektorat Daerah & & 20 & 28 & 3 & 51 \\
\hline 36 & Rumah Sakit Umum Daerah & & 127 & 51 & 2 & 180 \\
\hline 37 & Kantor Satuan Polisi Pamong Praja & 3 & 23 & 4 & & 30 \\
\hline 38 & $\begin{array}{l}\text { Kantor Perpustakaan \& Arsip } \\
\text { Daerah }\end{array}$ & & 4 & 6 & 1 & 11 \\
\hline 39 & $\begin{array}{l}\text { Kantor Pelyanan Perijinan } \quad \& \\
\text { Penanaman Modal Daerah }\end{array}$ & & 11 & 20 & 3 & 34 \\
\hline 40 & Sekretariat Kopri & & & 4 & & 4 \\
\hline 41 & Diperbantukan Di KPUD & & 5 & 5 & & 10 \\
\hline 42 & Sanggar Kegiatan Belajar & & 2 & 7 & & 9 \\
\hline 43 & Kantor Camat Namlea & 1 & 13 & 6 & & 20 \\
\hline 44 & Puskesmas Namlea & & 42 & 9 & & 51 \\
\hline 45 & Puskesmas Sawa & & 15 & 5 & & 20 \\
\hline 46 & UPTD P \& Kantor Kec. Namlea & & 4 & 2 & 9 & 15 \\
\hline 47 & Kantor Camat Waplau & & 12 & 5 & & 17 \\
\hline 48 & Puskesmas Waplau & & 18 & 4 & & 22 \\
\hline 49 & UPTD P \& Kantor Kec. Waplau & & 3 & 2 & 3 & 8 \\
\hline 50 & Kantor Camat Airbuaya & & 2 & 20 & 10 & 32 \\
\hline 51 & Puskesmas Wamlana & & 18 & 2 & & 20 \\
\hline \multicolumn{7}{|l|}{52} \\
\hline 53 & UPTD P \& Kantor Kec. Airbuaya & & 2 & 6 & 5 & 13 \\
\hline 54 & Kantor Camat Waeapo & & & & & \\
\hline 55 & Puskesmas Savana Jaya & & 29 & 8 & & 37 \\
\hline 56 & Puskesmas Mako & & 26 & 7 & & 33 \\
\hline 57 & Puskesmas Waelo & & 19 & 2 & & 21 \\
\hline 58 & Pustu Kaki Air & & & & & 0 \\
\hline 59 & Puskesmas Kayeli & & 3 & 3 & & 6 \\
\hline 60 & UPTD P \& Kantor Kec. Waeapo & & & & 19 & 19 \\
\hline 61 & Kantor Camat Batabual & & 12 & 2 & 1 & 15 \\
\hline 62 & Puskesmas Ilath & & 12 & 1 & & 13 \\
\hline 63 & UPTD P \& Kantor Kec. Batabual & & 1 & 3 & & 4 \\
\hline 64 & Kantor Camat Waelata & & 5 & 1 & & 6 \\
\hline 65 & Kantor Camat Lolong Guba & & 5 & 1 & & 6 \\
\hline 66 & Kantor Camat Fena Leisela & & 3 & & & 3 \\
\hline 67 & Kantor Camat Kaeily & & 2 & 1 & & 3 \\
\hline \multirow[t]{2}{*}{68} & Kantor Camat Lilialy & & 3 & 1 & & 4 \\
\hline & Buru & 28 & 2.050 & 1.808 & 307 & 4.193 \\
\hline
\end{tabular}

Sumber Data: Badan Kepegawaian Daerah Kab. Buru 2012 
Dari Tabel. 5 ini menunjukan jumlah PNS terbanyak ditempatkan pada dinas Pendidikan kebudayaan yakni sebanyak 2.162 melebihi $50 \%$ dari total jumlah PNS di pemda Kabupaten Buru.

E.

\section{Jumlah Tenaga Honorer Kabupaten}

Tabel. 6

Jumlah TH Menurut Dinas/Instansi Dan Jenis Kelamin

\begin{tabular}{|l|l|l|l|l|}
\hline \multirow{2}{*}{ Dinas / Instansi Pemerintah } & \multicolumn{3}{l|}{ Jenis Kelamin } \\
\cline { 3 - 5 } \multicolumn{2}{|l|}{$(\mathbf{1})$} & Laki-laki & Perempuan & Jumlah \\
\hline 1 & Bagian Ekonomi Pembangunan & $\mathbf{( 2 )}$ & $\mathbf{( 3 )}$ & $\mathbf{( 4 )}$ \\
\hline 2 & Dinas Koperasi Dan UKM & 8 & 3 & 6 \\
\hline 3 & Dinas Tenaga Kerja \& Transmigrasi & 17 & 6 & 14 \\
\hline 4 & Dinas Perhubungan & 22 & 18 & 35 \\
\hline 5 & Dinas Sosial & 14 & 22 & 29 \\
\hline 6 & Dinas Tata Kota \& Kebersihan & 20 & 18 & 36 \\
\hline 7 & Dinas Pertanian & 43 & 34 & 38 \\
\hline 8 & Dinas Peternakan & 23 & 13 & 37 \\
\hline 9 & Dinas Kelautan \& Perikanan & 31 & 15 & 46 \\
\hline 10 & Dinas Kehutanan & 41 & 9 & 50 \\
\hline 11 & Bappeda & 13 & 8 & 21 \\
\hline 12 & Badan Kepegawaian Daerah & 8 & 11 & 19 \\
\hline 13 & BPMD & 21 & 21 & 42 \\
\hline 14 & Badan Kesbang Linmas \& Politik & 7 & 9 & 16 \\
\hline 15 & Kantor Perpustakaan \& Arsip Daerah & 19 & 19 & 19 \\
\hline 16 & Diperbantukan di KPUD & 2 & 5 & 7 \\
\hline 17 & Sanggar Kegiatan Belajar & 3 & 8 & 11 \\
\hline 18 & Kantor Camat Namlea & 5 & 8 & 13 \\
\hline 19 & Kantor Camat Airbuaya & 10 & 2 & 12 \\
\hline 20 & Kantor Camat Waeapo & 5 & 5 & 10 \\
\hline 21 & Puskesmas Namlea & 1 & 5 & 6 \\
\hline 22 & UPTD P dan K. Kec. Namlea & 6 & 10 & 16 \\
\hline 23 & Puskesmas Airbuaya & 2 & 14 & 16 \\
\hline 24 & Puskesmas Mako & 1 & 5 & 6 \\
\hline 25 & SMA Negeri Waplau & 2 & 6 & 8 \\
\hline & Buru & $\mathbf{3 2 7}$ & 291 & $\mathbf{6 1 8}$ \\
\hline
\end{tabular}

Sumber Data : Badan Kepegawaian Daerah Kab. Buru 2012 
Dari Tabel. 6 ini menunjukan bahwa dalam penyelenggaraan pemerintahan di Kabupaten Buru masih memerlukan banyak tanaga PNS daerah agar mampu mengelola setiap program daerah sbagaimana tertuang dalam APBD dengan baik, efisien dan sistematis. 


\section{BAB VII \\ INDIKATOR TERJADINYA TINDAK \\ PIDANA KORUPSI DAN PENEGAKAN \\ HUKUM}

\section{A. Indikator Terjadinya Tindak Pidana Korupsi}

1. Tindak Pidana Korupasi Di Kabupaten Buru

a. Isu Publik Terhadap Tindak Pidana Korupsi di Kabupaten Buru

Dalam melihat perkembangan serta bagaimana tanggapan isu publik terhadap tidak pidana korupsi di Kabupaten Buru dapat tergambar melalui kontrol publik melaui kontrol sosial dari setiap elemen masyarakat dan elemen pemerintahan serta lembaga penegak hukum, dan tidak terkecuali kontrol sosial melaui media (cetak/elektronik) yang dalam pemberitaan dan akurasi datanya menggunakan metode jurnalistik yang dapat diuji kebenarannya sebagai isu publik.

Bertolak dari substansi penjelasan diatas maka dapat dilihan berbagai isu publik tentang indikasi tindak pidana korupsi di Kabupaten Buru dalam kurun waktu beberapa tahun terakhir ini:

1) Tersangka Korupsi Suap Rp1 Miliar

Terdakwa kasus korupsi Dana Alokasi Khusus (DAK) 2006 di Dinas Pendidikan, Kebudayaan, Pemuda dan Olahraga (PKPO) Kabupaten Buru, senilai Rp 6,7 miliar, Usman Banda, mengaku memberikan dana sebesar satu miliar rupiah kepada Kadis PKPO setempat, Hakim Fatsey. "Total dana yang saya berikan langsung kepada Kadis Hakim Fatsey sebesar satu miliar rupiah berdasarkan permintaan Kadis, dan uangnya diserahkan dalam beberapa kali," ujar Usman Banda di hadapan Majelis Hakim, saat persidangan di Pengadilan Negeri (PN) Ambon, Selasa. Usman Banda yang juga Bendaharawan Dinas PKPO 
Kabupaten Buru itu, 
didakwa melakukan tindak pidana korupsi dana DAK tahun 2006 yang mengakibatkan kerugian negara sebesar Rp1,635 miliar. Namun, tersangka Usman dalam persidangan mengakui, dana yang disebutkan sebagai kerugian negara itu. "Sebanyak Rp1 miliar di antaranya diberikan kepada Kadis Hakim Fatsey. Sisanya, Rp322 juta belum dikembalikan oleh Toko Buku NN yang beralamat di Ambon, sebagai pemenang tender pengadaan buku- buku pelajaran untuk 31 sekolah dasar di Kabupaten Buru, dan Rp215 juta lainnya, telah dikembalikan toko buku itu, dan uangnya juga telah diserahkan kepada Kadis Fatsey. "Sejumlah Rp215 juta yang dikembalikan toko buku NN tahun 2007 lalu itu, sudah saya serahkan kepada Kadis Fatsey tahun 2007 lalu, dan saya diberikan Rp50 juta. Itu pun saya gunakan untuk membeli handycam dan kamera digital sebagai kenang-kenangan. Namun kemudian diambil Kadis dan belum dikembalikan hingga sekarang," ujar Usman Banda. Mendengar penjelasan tersangka Usman Banda itu, Majelis Hakim yang diketuai Imam Supriyadi, SH, menjadi berang dan memarahi terdakwa karena tidak mengungkapkan fakta tersebut. saat persidangan terdahulu, yang menghadirkan Kadis Hakim Fatsey sebagai saksi. DAK tahun 2006 sebesar Rp6,7 miliar itu, diperuntukkan untuk proyek fisik berupa rehab bangunan, pengadaan 2.100 set kursi meja serta 60 unit lemari untuk menyimpan buku-buku, serta pengadaan buku paket SD di Kabupaten Buru. Terdapat 26 SD yang menerima dana sebesar Rp217 juta dan lima sekolah lainnya memperoleh Rp222 juta, di mana Rp109 juta dari setiap sekolah digunakan untuk pembangunan fisik dan pengadaan peralatan sekolah, sedangkannya sisanya untuk pembelian buku paket untuk siswa yang dimenangkan oleh toko 
buku NN. Namun kenyataannya, toko buku NN tidak melaksanakan kewajibannya sesuai dengan kontrak dengan alasan kondisi cuaca saat itu yang tidak memadai, sehingga diharuskan mengembalikan dana sebesar Rp537 juta, dan hanya baru mengembalikan Rp215 juta dan sisanya belum dikembalikan. Berdasarkan hasil pemeriksaan BPKP Maluku, kerugian negara akibat proyek yang belum selesia hingga tahun 2007 itu sebesar Rp1,635 miliar. [TMA, Ant. ${ }^{98}$

2) Tersandung Kasus Korupsi, Pejabat Dinas PKPO Buru Ditahan Kejari

Namlea - Menjelang tutup tahun 2010, Kejaksaan Negeri (Kejari) Namlea kembali menahan Kepala Kepegawaian Dinas Pendidikan Kebudayaan Pemuda dan Olahraga (PKPO) Kabupaten Buru, Bahri Umasugi. Bersama Bahri Umasugi, jaksa juga menggelandang mantan Kepala SD Unit 17, Arief Soamole ke bui. Keduanya tersandung kasus korupsi dalam ganti rugi tanah proyek Bandar Udara Namniwel, yang terindikasi merugikan negara mencapai satu milyar rupiah lebih. Kasih Pidsus Kejari Namlea, Ridwan Bugis yang dihubungi kemarin, membenarkan penahanan kedua tersangka. "Keduanya telah kami tahan dan dititip di Rutan Namlea sejak Kamis (23/12) pukul 11.30 WIT," jelas Ridwan. Menurut Ridwan, kedua tersangka ini dalam waktu dekat akan dipindahkan ke Rutan Kelas IIA Ambon guna menjalani persidangan di Pengadilan Negeri Ambon. "Belum ditentukan tanggalnya kapan keduanya akan dibawa ke Ambon, tapi secepatnya akan kami pindahkan," ujarnya. Informasi yang dihimpun wartawan menyebutkan, Kepala Bagian Kepegawaian Dinas PKPO Buru Bahri Umasugi ditetapkan sebagai tersangka dalam kapasitasnya 
sebagai Kepala Desa Sawah, dan Arief Soamole sebagai Tim Sembilan Desa Sawah, karena diduga kuat telah melakukan tindakan perbuatan melawan hukum sebagaimana diatur dalam pasal 2 dan pasal 3 UU Nomor: 31 tahun 1999 jo UU Nomor: 20 tahun 2002. Dalam kedudukannya sebagai Kades Sawah, Umasugi telah menerbitkan SK pembentukan Tim Sembilan Desa terdiri dari Arief Soamole dan kawan- kawan. Tim ini sangat agresif melakukan pengukuran lahan yang dibebaskan. Namun di kemudian hari diketahui ada terjadi penyimpangan dalam mendata penerima ganti rugi. Terjadi penggelembungan luas lahan perseorangan, lahan fiktif hingga mendata lahan tertentu menjadi tanah desa. Kemudian uang ganti rugi tersebut diterima dan ditengarai kuat mengalir ke kantong Umasugi dan kawan-kawan. Dari sekian nama penerima ganti rugi tanah proyek Bandara Namniwel, diketahui Arif Soamole juga turut didaftar sebagai penerima ganti rugi. Arif dicatat sebagai ahli waris pemilik tanah almarhum Pombo Soamole dengan luas tanah 33.000 meter persegi. Kemudian ia didata berhak atas ganti rugi tersebut dengan harga $\mathrm{Rp} 5.000$ per meter bujur sangkar dengan jumlah total ganti rugi sebesar Rp 165 juta. Saat sampai pembayaran ganti rugi tahap II, Arif Soamole sudah mengantongi uang sebesar Rp 94.079.700 setelah dipotong pajak. Saat masalah ganti rugi tanah tersebut ditangani Kejari Namlea, diketahui bahwa tanah milik almarhum Pombo Soamole tidak berada di dalam areal pembebasan lahan bandara Namniwel, sehingga diketegorikan tanah fiktif. Umasugi dan Soamole, datang ke Kantor Kejari Namlea pada Kamis pagi, namun keduanya tidak bersamaan. Soamole terlebih dahulu tiba di kantor kejaksaan sekitar 09.30 WIT. Sejam kemudian Umasugi baru tiba di kantor kejaksaan. Umasugi 
datang dengan diboncengi rekannya pegawai Dinas PKPO Buru, Mahmud G. Setelah menanda tangani berbagai berkas dokumen di kejaksaan, keduanya langsung dibawa dengan mobil tahanan ke Rutan Namlea. Bunyi serine mobil yang meraung-raung melewati Kantor UPTD Diknas Kancam Namlea sempat mengusik pegawai di intansi itu yang kantornya berjarak kurang seratusan meter dari rutan. "Biasa kalau sirene berbunyi dan stop di Rutan pasti ada tahanan baru," celetuk seorang pegawai. Namun para pegawai dinas pendidikan ini sontak ramai saat menyaksikan yang turun dari mobil adalah Umasugi dan Soamole."Ada apa ini, kenapa keduanya ditahan," celetuk salah seorang pegawai keheranan. Sementara itu, Ketua LIRA Maluku, Yan Sariwating yang dihubungi terpisah mengacungkan jempol atas langkah tegas aparat Kejari Namlea. Jaksa dinilai sangat cakap dan cekatan dalam mengungkap kasus tersebut. Namun LIRA tetap mendesak kejaksaan agar segera pula menetapkan panitia ganti rugi tanah sebagai tersangka dalam kasus tersebut, karena mereka hanya mengadopsi data dari tim Sembilan desa Sawah tanpa melakukan pendataan lebih terperinci di lapangan. Anwar Bessy, Raja Petuanan Liliyali, juga mendukung jaksa yang dinilainya sangat cemerlang dalam membongkar kasus korupsi ganti rugi tanah bandara Namniwel ini. "Dari laporan yang kami sampaikan ke kejaksaan hingga penetapan tersangka, kami patut acungkan pujian karena jaksa sangat sigap," puji Anwar Bessy. Anwar juga meminta jaksa agar secara khusus memeriksa dan menetapkan Kasie Pengukuran Tanah Kantor BPN Buru, Pieter Pakaila, karena dia dengan sengaja telah menerbitkan SK penerima ganti rugi tanah Bandara Namniwel tanpa melakukan pengukuran secara detail di lapangan. 
$>$ lanjut ----------.(S-31). ${ }^{99}$

\section{3) Putusan Kasasi MA Turun, Kadistan Buru Ditahan} Kejari

Namlea - Kepala Dinas Pertanian (Kadistan) Kabupaten Buru, Mahmud Tan, Rabu (15/12), sekitar pukul 11.30 WIT digelandang dengan mobil tahanan kejaksaan menuju Rumah Tahanan (Rutan) Namlea, karena terlibat korupsi. Kepala Seksi Pidana Khusus Kejari Namlea, M. Ridwan Bugis yang ditemui wartawan menjelaskan, Kadistan Buru, Mahmud Tan ditahan menyusul turunnya putusan Kasasi Mahkamah Agung RI yang tetap memvonis Mahmud bersalah. Putusan MA RI Nomor: $1299 \mathrm{~K} /$ pid.sus/2009, tanggal 8 Pebruari 2010. Putusan yang telah berkekuatan hukum tetap itu memvonis Mahmud dihukum penjara selama satu tahun enam bulan. Vonis MA RI itu lebih berat lagi dari vonis PN Ambon maupun vonis PT Maluku yang hanya menghukum terpidana hanya setahun penjara. Terpidana juga diharuskan membayar uang pengganti sebesar $\mathrm{Rp}$ 46.075.000 subsider tiga bulan penjara serta denda Rp 50 juta sub sider tiga bulan penjara. Mahmud Tan dituntut dua tahun penjara dan membayar denda Rp 50 juta serta uang pengganti $\mathrm{Rp}$

210 juta. Sebelumnya, jaksa pernah menuntut Mahmud Tan bersalah korupsi sebesar Rp 500 juta lebih proyek pengadaan alat pertanian menggunakan APBD Kabupaten Buru tahun 2001 dan 2002. Jaksa dalam tuntutan setebal 107 dalam menyebutkan hal yang memberatkan, terdakwa harus memberikan arahan proyek dapat dilaksanakan dengan baik, "Tapi justru mengambil keuntungan dalam pelaksanaan proyek tersebut." kata Andi Irfan jaksa penuntut waktu itu. Data yang berhasil dihimpun dari kejaksaan menyebutkan, amar putusan MA RI itu 
baru diterima Kantor Kejari Namlea, pekan lalu. Menyusul turunnya keputusan tersebut, Kajari Namlea, Sedia Ginting angsung mengeluarkan surat keputusan untuk segera mengeksekusi Mahmud Tan. Untuk kepentingan itu, Kejari Namlea sejak Jumat (10/12) lalu menyurati Tan untuk menghadap ke kantor kejaksaan. Surat itu diantar petugas kejaksaan tidak langsung diberikan kepada Mahmud Tan, melainkan diberikan kepada Sekda Buru, Juhana Sudrajat. Setelah itu baru diteruskan ke Mahmud Tan. $>$ lanjut --. (S-31). 100

4) Kejati Maluku Didesak Tuntaskan Dugaan Korupsi DAK Pendidikan Buru

Ambon - Majelis Pimpinan Wilayah Gerakan Pemuda Sehat Provinsi Maluku meminta Kejaksaan Tinggi (Kejati) Maluku mengusut tuntas indikasi korupsi dalam pengelolaan dana alokasi khusus (DAK) bidang Pendidikan Tahun Anggaran 2007 di Dinas Pendidikan, Kebudayaan, Pemuda dan Olahraga (PKPO) Kabupaten Buru senilai Rp 10,75 miliar. Ketua Majelis Pimpinan Wilayah Gerakan Pemuda Sehat Provinsi Maluku, Abdul Rahman Difinubun kepada wartawan, Sabtu (4/9) menandaskan, jika Kejati Maluku tidak mengusut indikasi korupsi dana DAK bidang pendidikan di kabupaten Buru, sama saja dengan kejati membiarkan masa depan peserta didik di Bumi Bupolo itu raib dan sengaja dirampas oleh oknum-oknum yang tidak bertanggung jawab. "Membiarkan dugaan korupsi DAK Pendidikan sama artinya Kejati membiarkan peserta didik menerima pelajaran prokorupsi, ini yang harus menjadi perhatian Kejati Maluku," ujarnya. Untuk diketahui Dana DAK Bidang Pendidikan tahun 2007 sebesar Rp 10,75 miliar itu disalurkan kepada 43 sekolah di Kabupaten Buru 
dengan rincian $\mathrm{Rp}$ 9,652 miliar untuk pendidikan

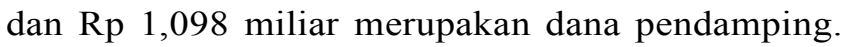
Masing-masing sekolah mendapatkan dana sebesar Rp 250 juta dan penyalurannya dibagi dalam empat tahap. Sesuai dengan sesuai petunjuk teknis DAK Pendidikan, pengelolaaan DAK tersebut ditangani secara swakelola oleh 43 sekolah dasar di Kabupaten Buru dan digunakan untuk tujuh jenis kegiatan antara lain, pembangunan rumah penjaga sekolah Rp 20,4 juta per unit, pembangunan gedung perpustakaan $\mathrm{Rp} 89,6$ juta per unit, rehabilitasi ruang kelas $R p 40$ juta, pengadaan meubelir $R p 30$ juta, pengadaan buku pelajaran $\mathrm{Rp} 30$ juta, pengadaan alat peraga $\mathrm{Rp} 30$ juta dan pengadaan mesin ketik $\mathrm{Rp} 10$ juta. Hal ini dibeberkan Pemantau Tingkat Wilayah Lembaga Pemantau Penyelenggara Negara Republik Indonesia (LPPNRI) Ruslan Hurasan wartawan, Kamis (2/9). Menurut Hurasan, dari dana DAK Bidang Pendidikan 2007 Kabupaten Buru senilai Rp 10,75 miliar tersebut, diketahui $\mathrm{Rp}$ 4,825 miliar masih disimpan di rekening dan tidak dapat dipertanggungjawabkan kebenaran dan kewajarannya. (S-26). ${ }^{101}$

5) Korupsi DAK Rp 6,1 M, Kadisdik Buru Hakim Fatsey Divonis 1 Tahun Penjara

Ambon - Pengadilan Tinggi (PT) Maluku menguatkan putusan Pengadilan Negeri (PN) Ambon tanggal 25 Maret 2010 Nomor 38/Pid.B/2009/PN.AB yang menjatuhkan vonis satu tahun penjara terhadap mantan Kepala Dinas Pendidikan, Pemuda dan Olahraga (PKPO) Kabupaten Buru Hakim Fatsey.

Selain itu, mantan Sekretaris Daerah (Sekda) Kabupaten Buru Selatan (Bursel) ini juga diperintah untuk membayar denda sebesar Rp 50 juta subsider tiga bulan penjara dan membayar uang pengganti sebesar Rp 65 juta subsider empat bulan penjara. 
101 Sumber Berita: Siwalimanews, Selasa, 7 September 2010 
Vonis penetapan putusan PT Maluku digelar dalam sidang pada Senin, 31 Mei 2010 lalu, yang dipimpin majelis hakim yang diketuai, Heri Sukemi, didampingi hakim anggota, Sutarto dan Daniel Rimpan, dan dibantu oleh panitera pembantu, Sofia Waitimu. "Putusan Hakim Fatsey baru saja turun kemarin (Senin-red) dari Pengadilan Tinggi Maluku kepada PN Ambon," jelas Kepala Humas PN Ambon, Genny de Fretes kepada wartawan di ruang kerjanya, Selasa (8/6). Hakim Fatsey dinyatakan terbukti melakukan tindak pidana korupsi Dana Alokasi Khusus (DAK) bidang pendidikan di Kabupaten Buru tahun anggaran 2006 sebesar Rp 6,1 miliar. Perbuatan terdakwa melanggar pasal 3 ayat 1 jo pasal 18 ayat (1) huruf a,b, ayat (2) dan ayat (3) UU Nomor 31 tahun 1999, yang telah dirubah dan ditambah dengan UU Nomor 20 tahun 2001 jo pasal 55 ayat (1) ke-1 KUHP jo pasal 64 (1) KUHP. Hakim PT Maluku dalam amar putusannya menyatakan, pertama, menerima banding yang diajukan oleh penasehat hukum terdakwa dan Jaksa Penuntut Umum (JPU), kedua, kuatkan putusan $\mathrm{PN}$ Ambon tanggal 25 Maret nomor 38/Pid.B/2009/PN.AB serta ketiga, memerintahkan agar terdakwa tetap ditahan. Menurut de Fretes, jika PT Maluku menguatkan putusan PN tersebut maka dengan sendirinya akan kembali kepada putusan PN tertanggal 25 Maret tersebut. Sebelumnya, JPU Ajid Latuconsina dan Siti Ariyani Ramlean menuntut Hakim Fatsey dengan pidana penjara selama enam tahun, denda sebesar Rp 200 juta subsider enam bulan kurungan serta membayar uang pengganti sebesar Rp 65 juta. (S-19). ${ }^{102}$ 


\section{6) Polres Buru Harus Serius Tangani Dugaan Korupsi Proyek BLK Rp 3,7 M}

Namlea - Polres Buru diminta serius mengusut dugaan korupsi dalam proyek Balai Latihan Kerja (BLK) di Kabupaten Buru yang dibiayai dana stimulan tahun anggaran 2009 sebesar Rp.3,7 miliar. "Kami mendapat informasi bahwa Polres Buru sudah menangani masalah tersebut . Yang mengadukannya ke polisi justru Kuasa Pengguna Anggaran (KPA) yang juga Plt Kadis Nakertrans Buru, Ir H. Harun Awad, karena itu kami dari LIRA Maluku sangat tertarik untuk mengawal kasus ini sampai tuntas di pengadilan dan jangan sampai terhenti di tengah jalan," ungkap Ketua Lumbung Informasi Rakyat (LIRA) Maluku, Yan Sariwating kepada Siwalima, Rabu (26/5). Sementara itu, Kadis Nakertrans Buru, Ir. H. Harun Awad yang dihubungi terpisah membenarkan, yang mengadukan masalah tersebut ke polisi. Ia juga sudah beberapa kali diperiksa, tapi tidak dirinci materi pemeriksaan dan apa saja yang disampaikannya ke polisi karena dia harus buru-buru menemui Sekda. Sementara itu, Sariwating lebih jauh membeberkan, dari hasil penelusuran LIRA Maluku, proyek BLK yang dibiayai dana stimulan tahun anggaran 2009 ini terkesan sangat dipaksakan. Pasalnya, KPA yang juga Kadis Nakertrans Buru ini baru ke Jakarta untuk menerima DIPA pada bulan Nopember tahun 2009 lalu, atau waktunya sudah sangat mepet dengan akhir tahun anggaran. Dari hasil investigasi LIRA, akui Sariwating, ditemukan ada beberapa kejanggalan, yakni bahwa pihak Dinas Nakertrans sebagai pemilik proyek telah mengusulkan agar proyek tersebut dibiayai dana stimulan. Tapi ada pihak lain yang memperjuangkan proyek tersebut masuk ke Kabupaten Buru. Kejanggalan lainnya, setelah itu dibuatlah seakan- 
akan ada terjadi proses tender dengan menunjuk Ibrahim Mewar dkk sebagai panitia tender proyek tersebut. Padahal faktanya, tender tidak pernah ada. Kalaupun ada , maka itu hanya secara administrasi belaka dengan ditunjuknya Sarina Jaya Abadi, perusahan milik Nasir Mamulati sebagai pemenang tender proyek tersebut. Yang mencurigai, ada intervensi kuat dari beberapa pihak, karena setelah itu proyek tersebut ditangani oleh tiga orang, yakni Nasir Mamulati alias Ma,sud, Ali Soleman dan Ongko Peng. Bahkan sebelum mengawali pekerjaan, sudah terjadi pencairan dana sebesar Rp.2,3 miliar atau 65 persen dana ke rekening Direktur Sarina Jaya Abadi. Dari sisi administrasi, akui Sariwating, KPA sudah melakukan keteledoran. Tapi keteledoran itu pasti ada apa-apanya, sehingga polisi harus bisa menggali informasi lebih dalam lagi terhadap kemungkinan keterlibatan atau intervensi pihak lain sampai bisa dicairkannya dana tersebut. "Karena KPA ini yang bertindak sebagai pelapor, sekalipun nanti fakta hukum dia juga turut bersalah, polisi sebaiknya jangan lebih awal menetapkan dia sebagai tersangka," pinta Sariwating. Sariwating meminta polisi agar mengejar dan mencari tahu realisasi fisik pekerjaan di lapangan, apakai sampai dengan saat dilaporkan sudah sesuai dengan anggaran yang dikeluarkan atau tidak. Bila tidak sesuai, maka pihak kontraktor yang harus lebih dahulu bertangungjawab. "Kalau fisik tidak sampai 65 persen, maka tangkap dahulu kontraktornya tanpa pandang bulu," tandasnya. Sementara itu, sumber Siwalima menuturkan, polisi sudah mengcross check dengan fisik di lapangan. Kemudian ditemukan kenyataan fisik proyek tidak sesuai dengan realisasi dana 65 persen. Dari tiga rekanan yang melaksanakan proyek tersebut, akui sumber ini, pekerjaan lapangan tergolong terlambat 
yakni yang ditangani oleh Ali Soleman. Tapi sumber ini tidak mengetahui pasti apakah oknum pengusaha ini juga ikut kecipratan dana lebih dari fisik pekerjaan yang dilaksanakannya. Untuk mengusut masalah ini sampai tuntas, polisi sudah memeriksa pula beberapa anggota panitia tender, Ibrahim Mewar dkk. Juga telah diagendakan, untuk memeriksa Direktur CV Sarina Jaya Abadi, Nasir Mamulati. (S-31). ${ }^{103}$

7) Fiktif, Proyek Anakan Kakao Rp 10 M di Empat Desa di Kabupaten Buru

Namlea - Proyek anakan kakao seluas 800 hektar di Kabupaten Buru yang dibiayai ABPN TA 2009 senilai Rp 10 milyar lebih, ternyata bermasalah. Ada empat desa diketemukan proyeknya benar-benar fiktif. Berdasarkan penelusuran wartawan Siwalima di Namlea, empat desa yang diketahui proyek anakan kakao benarbenar fiktif masing-masing Desa Kayeli dan Desa Masarete di Kecamatan Waeapo, Desa Seith di Kecamatan Batabual dan Desa Rehariat di Kecamatan Airbuaya. Sesuai planning awal, Desa Seith seharusnya mendapat bantuan anakan kakao seluas 75 hektar, Kayeli dan Masarete masingmasing seluas 50 hektar, serta Rehariat seluas 25 hektar. Saat wartawan Siwalimanews turun langsung ke desa- desa tersebut, petani peserta penerima bantuan mengaku sampai kini belum menerima satu pohonpun anakan tanaman kakao. Para petani di empat desa tersebut mengaku, hanya menerima bantuan tanaman sela, seperti benih kacang tanah, bawang dan hotong. Benih tersebut sudah ditanaman sejak tahun lalu dan hasilnya sudah mereka panen. Selain diketemukan ada empat desa yang benar-benar anakan kakaonya fiktif. di sejumlah desa lainnya petani penerima bantuan kakao juga mengaku tidak mendapat benih sesuai aturan main. Awalnya 
103 Sumber Berita: Siwalimanews, Kamis, 27 Mei 2010 
dijanjikan per hektar akan mendapat 1.000 anakan kakao. Tapi yang mereka terima hanya 300 anakan per hektar. Khusus di Kecamatan Airbuaya, hanya satu kelompok tani di Desa Airbuaya yang mendapat bantuan sebanyak 600 anakan kakao per hektar. Sesuai agenda Desa Airbuaya mendapat pasokan anakan kakao sebanyak $75.000 \quad\left(\begin{array}{lll}75 & \text { ha }\end{array}\right)$, Waemangit

75.000 (75 ha), Wamlana 50.000 (50 ha), Rehariat 25.000 (25 ha) dan Waspait 75.000 (75 ha). Proyek anakan kakao di empat desa di Kecamatan Waplau juga bermasalah. Bantuan yang diberikan kepada petani juga tidak mencapai 1.000 anakan per hektar. Rata-rata petani hanya mendapat 300 anakan per ha. Kepala Desa Lamahang, Bahrim Tasidjawa yang ditemui, mengaku desanya harus mendapat bantuan

25.000 anakan kakao. Tapi pihak kontraktor hanya memberikan 10.000 anakan. "Beta tolak tanda tangan surat-surat yang disodorkan kontraktor tahun lalu karena bantuannya tidak lengkap," ungkap Bahrim Tasidjawa. Ketua LIRA Maluku, Yan Sariwating, yang dihubungi terpisah, mendesak aparat Kejaksaan Tinggi Maluku agar segera turun tangan mengusut proyek anakan kakao tersebut. Yan mengaku heran kalau rekanan proyek anakan kakao CV Indotek dari Jember, Jatim, bisa begitu mudah mencairkan dana proyek saat masih banyak masalah di lapangan. "Dan ternyata sampai kini proyeknya bermasalah dan ada yang fiktif. Ini benar-benar sangat keterlaluan. Lantas dimana peran Inspektorat Propvinsi Maluku. Kalau Inspektorat sebagai lembaga pengawasan internal bisa melaksanakan tugasnya dengan baik, maka tidak mungkin ada masalah seperti ini," tandas Sariwating. Sariwating mendesak Kejaksaan Tinggi (Kejati) Maluku segera turun tangan mengusut masalah tersebut dengan memeriksan pihak rekanan 
dan Kepala Dinas Pertanian Provinsi Maluku, Ir. Rudi 
Latuheru. Sariwating mengungkapkan, masalah ini sempat diselidiki Kantor Kejaksaan Negeri Namlea, tapi tidak jelas kelanjutan dari perkembangan penyelidikan tersebut." Karena itu sebaiknya, Kejati Maluku yang menghandle langsung masalah ini," pintanya. Sementara itu, Kepala Dinas Pertanian Kabupaten Buru, Ir Mahmud Tan dan KPA Distan Buru, Masrin yang dihubungi terpisah menjelaskan, proyek peremajaan kakao di daerahnya pada tahun anggaran 2009 lalu seluas 800 ha. Namun pihak kabupaten hanya bertanggungjawab membiayai tanaman sela, seperti bibit kacang tanah, bawang merah, hotong dan anakan salak serta handspayer. $>$ Lanjut --. (S-31). 104

8) Korupsi Anggaran Sertifikasi, Mantan Kepala BPN Buru Divonis 1,3 Tahun

Ambon - Majelis hakim Pengadilan Negeri (PN) Ambon memvonis mantan Kepala Badan Pertanahan Nasional (BPN) Kabupaten Buru, Abdul Azis Romeon dengan hukuman 1,3 tahun penjara potong masa tahanan. Dia juga divonis denda Rp 50 juta sub sider satu bulan penjara dan membayar uang pengganti sebesar Rp 120 juta sub sider enam bulan penjara serta membayar biaya perkara sebesar Rp 5000, dengan perintah terdakwa tetap ditahan. Vonis dibacakan dalam sidang, Senin (7/3), yang dipimpin majelis hakim, masing-masing Sunggul Simanjuntak sebagai ketua, didampingi Agam Sarif Baharudin, Editerial sebagai hakim anggota. Dalam amar putusannya, majelis hakim mengatakan terdakwa terbukti secara sah melakukan tindak pidana korupsi anggaran sertifikasi lahan pertanian yang menyebabkan negara mengalami kerugian. Perbuatan tersebut terdakwa lakukan dengan cara korupsi anggaran sertifikasi lahan pertanian pada sentra 
produksi tanaman pangan, sertifikasi lahan pertanian pada sentra produksi hortikultura dan sertifikasi lahan pertanian pada sentra produksi perkebunan pada kegiatan pengelolaan lahan dan air tahun anggaran 2006 di Kabupaten Buru. Akibat perbuatan terdakwa sesuai hasil audit Badan Pemeriksa Keuangan dan Pembangunan (BPKP) Perwakilan Provinsi Maluku, negara mengalami kerugian sebesar Rp 156.704.545. Perbuatan terdakwa melanggar pasal 3 jo pasal 18 ayat (1) huruf b, ayat (2) dan ayat (3) UU Nomor 31 tahun 1999 jo UU Nomor 20 Tahun 2001 tentang pemberantasan Tindak Pidana Korupsi (Tipikor). Vonis 1,3 tahun penjara lebih ringan dibandingkan tuntutan Jaksa Penuntut Umum (JPU) yang menuntut terdakwa dengan hukuman dua tahun penjara. (S-32). ${ }^{105}$

Dengan demikian dapat dilihat adanya tindak pidana korupsi yang begitu besar di Kabupaten Buru mealui isu publik yang di jelaskan. Namun demikian selain yang dijelaskan masi banyak juga tindak pidana korupsi yang tidak sempat tersampaikan dalam isu publik tersebut, sehingga tindak pidana korupsi di Kabupaten Buru haruslah manjadi perhatian yang serius oleh semua komponen di Kabupaten Buru baik pemerintah daerah, instansi perangkat daerah, instansi perangkat vertikal negara di Kab. Buru maupun elemen masyarakat serta yang terpenting oleh aparat atau lebaga penegak hukum.

\section{Faktor-Faktor Penyebab Terjadinya Tindak Pidana Korupsi}

Secara umum dapat di jelaskan dan sejatinya, ada begitu banyak pengertian dari korupsi yang disampaikan oleh para ahli. Huntington (1968) memberikan pengertian korupsi sebagai perilaku pejabat publik yang menyimpang 
dari norma-norma yang diterima oleh masyarakat, dan perilaku menyimpang ini ditujukan dalam rangka memenuhi kepentingan pribadi. Menurut Dr. Kartini Kartono, korupsi adalah tingkah laku individu yang menggunakan wewenang dan jabatan guna mengeduk keuntungan pribadi, merugikan kepentingan umum. Korupsi juga sering dimengerti sebagai penyalahgunaan kekuasaan dan kepercayaan untuk keuntungan pribadi. Namun korupsi juga bisa dimengerti sebagai perilaku tidak mematuhi prinsip

"mempertahankan

jarak".

"Mempertahankan jarak" ini maksudnya adalah dalam mengambil sebuah keputusan, baik di bidang ekonomi, politik, dan sebagainya, permasalahan dan kepentingan pribadi atau keluarga tidak memainkan peran. Selain itu, korupsi juga dapat dikatakan sebagai representasi dari rendahnya akuntabilitas birokrasi publik. 106

Secara umum sebab-sebab atau faktor-faktor Penyebab Korupsi terbagi Internal: Dorongan dari dalam diri sendiri, Eksternal: Dorongan dari luar atau kondisi lingkungan, Faktor Enrichment: Korupsi terjadi karena adanya willingness dan opportunity (internal \& eksternal faktor). Faktor internal terkait dengan kualitas moral seseorang. Individu yg bermoral tinggi cenderung tidak melakukan korupsi, tetapi iman seseorang ada pasang dan surutnya. Sehingga, menggantungkan proses governance kepada seorang pemimpin saja tidaklah cukup. Diperlukan sistem yang mampu mencegah terjadinya korupsi. Sistem yang (1) membatasi discretionary (D) seseorang, (2) mencegah terjadinya monopoli (M) dan (2) mendorong akuntability (A), akan mampu menekan tingkat korupsi....... KORUPSI $=\mathrm{D}+\mathrm{M}-\mathrm{A} .{ }^{107}$ Faktor Eksternal adalah dipengarugi oleh Sistem hukum Sistem politik

106 Kumorotomo, Wahyudi. 2005. Etika Administrasi Negara, Rajawali Pers: Jakarta. hal. V

107 Fathur Rohman, 2009, Matakuliah Anti-Korupsi, Faktor-Faktor Penyebab Korupsi, Universitas Paramadina, Jakarta. 
Budaya lembaga Struktur dan sistem sosial Sistem dan kualitas pendidikan pendidikan. ${ }^{108}$

Dari dua faktor pokok penyebab korupsi diatas mengindikasikan secara internal maupun eksternal banyak faktor yang menyebabkan terjadinya korupsi, diantara adalah korporatisme. Korporatisme, dalam khasanah literature ekonomi-politik, sering disepadankan dengan praktek politik di mana pemerintah atau penguasa berinteraksi secara tertutup (tidak diketahui oleh masyarakat) dengan sektor swasta besar (pengusaha kelas kakap). Dalam ketertutupan tersebut, transaksi ekonomi mapun politik terjadi hanya untuk kepentingan segelintir kelompok kepentingan (interest group) yang terlibat di dalamnya. Biasanya transaksi politik maupun eknomi yang seperti ini terjadi secara informal dalam tatanan hukum yang kabur atau tatanan hukum yang memihak kepentingan kelompok kecil tersebut. Adanya persengkongkolan seperti ini membuka peluang besar bagi hukum untuk dipermainkan (mafia hukum) sehingga hukum seorah-olah telah dipegang oleh tangan-tangan tertentu. ${ }^{109}$

Dari pandangan tentang faktor-faktor penyebab terjadinya korupsi diatas selaras dengan kajian dan penelitian penulis secara metodologis selama penelitian ini juga dapat menyampaikan pandangan secara substansial, yakni baik secara internal maupun eksternal penyebab terjadinya tindak pidana korupsi secara umum di Indonesia dan berlaku juga secara Khusus di Kabupaten Buru adalah sebagai berikut :

a. Melemahnya Kontrol Agama: Indonesia dikenal sebagai bangsa religius yang tentu akan melarang tindak korupsi dalam bentuk apapun. Kenyataan di lapangan menunjukkan bila korupsi masih berjalan subur di tengah masyarakat. Situasi paradok ini menandakan

109 Rachbini, Didik J. 2004, Ekonomi Politik, Kebijakan dan Strategi

Pembangunan, Granit, Jakarta. hal. 9 
bahwa ajaran agama kurang diterapkan dalam kehidupan.

\section{b. Kelemahan Sistem pengangkatan pejabat partai politik} dan pejabat pemerintahan : Kelemahan pengkaderan partai dan pencalonan pemimpin partai atau yang akan menjadi pejabat publik, legislatif atau pengawas pejabat publik yang tidak transparan dan berbiaya tinggi memicu terjadi korupsi sebagai tindakan untuk mencapai balik modal saat biaya mahal yang telah dikeluarkan saat menjadi pejabat partai dan pejabat publik

c. Kurang Memiliki Keteladanan Pimpinan : Posisi pemimpin dalam suatu lembaga formal maupun informal mempunyai pengaruh penting bagi bawahannya. Bila pemimpin tidak bisa memberi keteladanan yang baik di hadapan bawahannya, misalnya berbuat korupsi, maka kemungkinan besar bawahnya akan mengambil kesempatan yang sama dengan atasannya.

d. Tidak Memiliki Kultur Organisasi yang Benar : Kultur organisasi biasanya punya pengaruh kuat terhadap anggotanya. Apabila kultur organisasi tidak dikelola dengan baik, akan menimbulkan berbagai situasi tidak kondusif mewarnai kehidupan organisasi. Pada posisi demikian perbuatan negatif, seperti korupsi memiliki peluang untuk terjadi.

e. Terbatasnya Sistem Akuntabilitas yang Benar di Instansi Pemerintahan yang Memadai di Tingkat Pusat dan Daerah : Pada institusi pemerintahan umumnya belum merumuskan dengan jelas visi dan misi yang diembannya dan juga belum merumuskan dengan tujuan

dan sasaran yang harus dicapai dalam periode tertentu guna mencapai misi tersebut. Akibatnya, terhadap instansi pemerintah sulit dilakukan penilaian apakah instansi tersebut berhasil mencapai sasaranya atau tidak. Akibat lebih lanjut adalah kurangnya perhatian pada 
efisiensi penggunaan sumber daya yang dimiliki. Keadaan ini memunculkan situasi organisasi yang kondusif untuk praktik korupsi.

f. Kelemahan Sistem Pengendalian Manajemen dan Tata Kelola Pemerintahan di Daerah : Pengendalian manajemen dan tata kelola merupakan salah satu syarat bagi tindak pelanggaran korupsi dalam sebuah organisasi. Semakin longgar/lemah pengendalian manajemen dan tata kelola pemerintahan maupun sebuah organisasi akan semakin terbuka perbuatan tindak korupsi anggota atau pegawai di dalamnya.

g. Sistem Manajemen dan Tata Kelola Pemerintahan Cendrung Menutupi Korupsi di Organisasi : Pada umumnya jajaran manajemen penyelenggara pemerintahan selalu menutupi tindak korupsi yang dilakukan oleh segelintir oknum dalam organisasi. Akibat sifat tertutup ini pelanggaran korupsi justru terus berjalan dengan berbagai bentuk.

h. Aspek Tempat Individu dan Organisasi Berada : Nilainilai di masyarakat kondusif untuk terjadinya korupsi Korupsi bisa ditimbulkan oleh budaya masyarakat. Misalnya, masyarakat menghargai seseorang karena kekayaan yang dimilikinya. Sikap ini seringkali membuat masyarakat tidak kritis pada kondisi, misalnya dari mana kekayaan itu didapatkan. Hal ini juga sangat mendorong terjadinya korupsi di Kab. Buru.

i. Aspek Peraturan Perundang-Undangan : Korupsi mudah timbul karena adanya kelemahan di dalam peraturan perundang-undangan yang dapat mencakup adanya peraturan yang monopolistik yang hanya menguntungkan kroni penguasa, kualitas peraturan yang kurang memadai, peraturan yang kurang disosialisasikan, sangsi yang terlalu ringan, penerapan sangsi yang tidak konsisten dan pandang bulu, serta lemahnya bidang evaluasi dan revisi peraturan perundang-undangan. 
j. Kurangnya Tingkat Kesejahteraan dalam Aspek Ekonomi Bagi Aparatur Negara Maupun di Daerah: Gaji Aparatur Negara yang tidak sebanding dengan kebutuhan yang semakin tinggi. Apalagi pada daerah- daerah Indonesia timur dan wilayah kepualuan sepertihalnya di Kabupaten Buru. Olehnya itu tingkat upah dan gaji pekerja di sektor publik penghasilan

seorang pegawai dari suatu pekerjaan selayaknya memenuhi kebutuhan hidup yang wajar. Bila hal itu tidak terjadi maka seseorang akan berusaha memenuhinya dengan berbagai cara. Tetapi bila segala upaya dilakukan ternyata sulit didapatkan, keadaan semacam ini yang akan memberi peluang besar untuk melakukan tindak korupsi, baik itu korupsi waktu, tenaga, pikiran dalam arti semua curahan peluang itu untuk keperluan di luar pekerjaan yang seharusnya.

k. Sumber Daya Manusia (Aparatur Pemerintahan) dalam Mengelola Manajemen dan Tatakelola Pemerintahan Masih minim dan terbatas : keterbatasan sumber daya manusia yang handal dalam mengelola akuntan manajemen dan tatakelola pemerintahan di daerah yang masih kurang dan terbatas membuka ruang bagi melemahnnya manajemen yang baik dan kontrol yang kurang efektif dan efesien, dan memberikan peluang untuk korupsi;

1. Aspek Individu Pelaku Sifat Tamak Manusia :

Kemungkinan orang melakukan korupsi bukan karena orangnya miskin atau penghasilan tak cukup. Kemungkinan orang tersebut sudah cukup kaya, tetapi masih punya hasrat besar untuk memperkaya diri. Unsur penyebab korupsi pada pelaku semacam itu datang dari dalam diri sendiri, yaitu sifat tamak dan rakus.

m. Moral Individu yang Kurang Kuat : Seorang yang moralnya tidak kuat cenderung mudah tergoda untuk melakukan korupsi. Godaan itu bisa berasal dari atasan, 
teman setingkat, bawahanya, atau pihak yang lain yang memberi kesempatan untuk itu.

n. Kebutuhan Hidup yang Mendesak : Dalam rentang kehidupan ada kemungkinan seseorang mengalami situasi terdesak dalam hal ekonomi. Keterdesakan itu membuka ruang bagi seseorang untuk mengambil jalan pintas diantaranya dengan melakukan korupsi.

o. Gaya Hidup yang Konsumtif di Kota-Kota Besar dan di daerah : Kehidupan di kota-kota besar maupun di daerah yang minim budaya kerja dalam dunia usaha acapkali mendorong gaya hidup seseong konsumtif. Perilaku konsumtif semacam ini bila tidak diimbangi dengan pendapatan yang memadai akan membuka peluang seseorang untuk melakukan berbagai tindakan untuk memenuhi hajatnya. Salah satu kemungkinan tindakan itu adalah dengan korupsi.

p. Malas atau Tidak Mau Bekerja : Sebagian orang ingin mendapatkan hasil dari sebuah pekerjaan tanpa keluar keringat alias malas bekerja. Sifat semacam ini akan potensial melakukan tindakan apapun dengan cara-cara mudah dan cepat, diantaranya melakukan korupsi.

Dari berbegai kenyataan dalam penyelasan penyebab terjadinya tindak pidana korupsi, maka perlu adanya pencegahan lbih awal dengan melihat indikator sebab timbulnya korupsi sehingga dapat diminimalisir serta tidak mengabaikan penegakan hukum yang tegas dan berwibawa terhadap tercapainya kepastian hukum dan keadilan.

\section{Indikator Terjadinya Tindak Pidana Korupsi}

a. Indikator Dalam Pengelolaan Anggaran Pendapatan Belanja Daerah

Dalam mengukur kualitas pengelolaan keuangan pemerintah daerah Kabupaten Buru suda tentu harus dilihat dari pengelolaan anggaran pendapatan belanja daerah (APBD) Kabupaten Buru pada tiap tahun anggarannya. Oleh karena itu maka dapat dilihat pada 
rangkuman APBD Kabupaten Buru pada 5 (lima) tahun terakhir:

Tabel. 7

Rangkuman APBD Kabupaten Buru Tahun 2008 s/d 2012

\begin{tabular}{|l|l|l|l|l|}
\hline No & Tahun & Pendapatan & Belanja & Keterangan \\
\hline$(1)$ & $(2)$ & $(3)$ & $(4)$ & $(5)$ \\
\hline 1 & 2008 & Rp. 401.611.765.073,26 & Rp. 419.556.045.766,98 & $\begin{array}{l}\text { Defisit } \\
\text { Rp. 17.944.280.693,72 }\end{array}$ \\
\hline 2 & 2009 & Rp. 289.437.626.593,28 & Rp. 317.533.104.752,47 & $\begin{array}{l}\text { Defisit } \\
\text { Rp. 28.095.478.159,19 }\end{array}$ \\
\hline 3 & 2010 & Rp. 401.422.598.334,23 & Rp. 372.788.648.939,24 & $\begin{array}{l}\text { Surplus } \\
\text { Rp. 28.633.949.394,99 }\end{array}$ \\
\hline 4 & 2011 & Rp. 451.666.805.589,41 & Rp. 448.323.327.838,72 & $\begin{array}{l}\text { Surplus } \\
\text { Rp. 3.343.477.750,69 }\end{array}$ \\
\hline 5 & $\begin{array}{c}2012 \\
\text { Sumber Data }: \text { Ba. Peng. Keuangan dan Kekayaan }\end{array}$ & $\begin{array}{l}\text { Rp. 444.794.205.027,36 } \\
\text { Rp. 445.115.163.517,93 }\end{array}$ & $\begin{array}{l}\text { Defisit } \\
\text { Rab. 390,57 }\end{array}$ \\
\hline
\end{tabular}

Buru 2014

Dari data tabel. 7 diatas maka dapat terlihat bahwa target pencapaian pengelolaan APBD belum berjalan secara konsisten dengan adnya surplus pada tahun 2010 dan 2011 sedang defisit pada tahun 2008, 2009 dan 2012. Ini dikarenakan faktor-faktor sebagai berikut:

1) Belum maksimalnya perbaikan sistem kerja serta terbatasnya sarana dan prasarana yang mendukung pencapaian target pengelolaan APBD

2) Masih terbatasnya kapasitas sumberdaya aparatur melalui pembinaan dan pelatihan internal ataupun melalui peningkatan jenjang pendidikan sebagaimana tergambar dalam tabel-tabel diatas (Kondisi aparatur di Kab. Buru)

3) Lemahnya tingkat koordinasi antar SKPD dalam pelaksanaan tugas dan fungsi secara sinergis 
4) Lemahnya tingkat koordinasi pemerintah Kab. Buru dengan Pemerintah propinsi, pemerintah Pusat dan instansi vertikal lainnya

5) Kurang maksimalnya pengelolaan sumber pendapatan di sektor pajak daerah Kabupaten Buru

6) Masih kurang optimal pengelolaan potensi SDA yang ada oleh pemerintah Kab. Buru.

7) Belum transparansinya proses pembagian dana bagi hasil dari pusat kepada Pemerintah Kab. Buru.

8) Masih lemahnya akuntabilitas pengelolaan keuangan daerah pada Pemerintah Kab. Buru

b. Indikator Dalam Opini Hasil Pemeriksaan BPK-RI Atas Laporan Keuangan Pemerintah Daerah Kab. Buru

Opini hasil pemerikasaan BPK-RI Perwakilan Maluku atas laporan keuangan pemerintah daerah Kabupaten Buru merupakan gamabaran tentang akuntabilitas pengelolaan APBD Kabupaten Buru yang sesuai dengan sistem pengelolaan keuangan di adaerah ataukah tidak. Oleh karena itu dapat dilihat opini hasil pemeriksaan BPK-RI Perwakilan Maluku atas laporan keuangan pemerintah daerah Kab. Buru 5 (lima) tahun terakhir:

Tabel. 8

Opini Hasil Pemeriksaan BPK-RI Atas Laporan Keuangan Pemerintah Daerah Kab. Buru Tahun 2008 s/d 2013

\begin{tabular}{|l|l|l|ll|}
\hline No & Tahun & Opini BPK & Keterangan & \\
\hline (1) & $\mathbf{( 2 )}$ & $\mathbf{( 3 )}$ & $\mathbf{( 4 )}$ & \\
\hline 1 & 2008 & DISCLAIMER & $\begin{array}{l}\text { BPK RI Tidak } \\
\text { Berpendapat }\end{array}$ \\
\hline 2 & 2009 & DISCLAIMER & $\begin{array}{l}\text { BPK RI Tidak } \\
\text { Berpendapat }\end{array}$ \\
\hline 3 & 2010 & DISCLAIMER & $\begin{array}{l}\text { BPK RI Tidak } \\
\text { Berpendapat }\end{array}$ \\
\hline
\end{tabular}




\begin{tabular}{|l|l|l|ll|}
\hline 4 & 2011 & DISCLAIMER & $\begin{array}{l}\text { BPK RI Tidak } \\
\text { Berpendapat }\end{array}$ & \\
\hline 5 & 2012 & DISCLAIMER & $\begin{array}{l}\text { BPK RI Tidak } \\
\text { Berpendapat }\end{array}$ & \\
\hline 6 & 2013 & WDP & $\begin{array}{l}\text { Wajar } \\
\text { Pengecualian }\end{array}$ & Dengan \\
\hline
\end{tabular}

Sumber Data : Inspektorat Kab. Buru 2014

Dengan demikian Opini Hasil Pemeriksaan BPKRI Perwakilan Provinsi Maluku terhadap Laporan Keuangan Pemerintah Daerah Kabupaten Buru untuk tahun 2008-2012 adalah disclaimer. Adapun penyebab disclaimer tersebut antara lain: ${ }^{110}$

1) Kurangnya SDM aparatur dibidang teknis dan akuntansi;

2) Adanya persedian yang dilaporkan namun tidak dicatat dan diinventarisasi secara memadai;

3) Terdapat investasi non permanen atas dana bergulir tidak ditatausahakan secara memadai;

4) Pemanfaatan, pengelolaan dan pencatatan asset belum tertata secara baik.

\section{B. Proses Penegakan Hukum Bagi Pelaku Tindak Pidana Korupsi}

1. Penegakan Hukum Tindak Pidana Korupsi Di Tingkat Penyelidikan dan Penyidikan

Berikut dapat dijelaskan tentang penanganan, penegakan hukum tindak pidana korupsi di tingkat penyelidikan dan penyidikan pada Kepolisian Resort Pulau Buru dalam bentuk tabel sebagaimana berikut :

110 Sumber : Data Inspektorat Kab. Buru 2013 

Tabel. 9

Data Penanganan Kasus Korupsi Tahun 2006 s/d 2013 Sat Reskrim Polres Pulau Buru111

\begin{tabular}{|c|c|c|c|c|}
\hline Tahun & Tersangka & $\begin{array}{ll}\text { No. } & \text { Laporan } \\
\text { Polisi } & \end{array}$ & Gar Pasal & TKP \\
\hline 1 & 2 & 3 & 4 & 5 \\
\hline 2006 & NIHIL & NIHIL & NIHIL & NIHIL \\
\hline 2007 & - & - & - & - \\
\hline 2008 & - & - & - & - \\
\hline 2009 & - & - & - & - \\
\hline 2010 & - & - & - & - \\
\hline 2011 & $\begin{array}{l}\text { LA UNE } \\
\text { BUTON }\end{array}$ & $\begin{array}{l}\text { LP- } \\
\text { B/04/K/I/2011/ } \\
\text { RESKRIM,TGL } 24 \\
\text { JANUARI } 2011\end{array}$ & 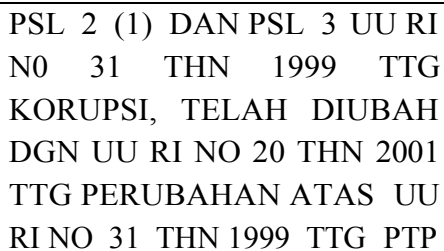 & $\begin{array}{l}\text { DESA } \\
\text { WAELIHANG } \\
\text { TTG RASKRIN }\end{array}$ \\
\hline
\end{tabular}

111 Sumber Data: Satreskrim Polres Pulau Buru, 2014 


\begin{tabular}{|c|c|c|c|c|}
\hline & & KORUPSI & & \\
\hline $\begin{array}{l}\text { Ir. HARUN } \\
\text { AWAT }\end{array}$ & $\begin{array}{l}\text { LP- } \\
\text { B/55.K/V/2011/ } \\
\text { RESKRIM, TGL } 06 \\
\text { MEI } 2011\end{array}$ & $\begin{array}{l}\text { PRIMER PSL } 3 \text { SUB. PSL } 9 \text { UU } \\
\text { RI N0 } 31 \text { THN } 1999 \text { TTG } \\
\text { KORUPSI, TELAH DIUBAH } \\
\text { DGN UU RI NO } 20 \text { THN } 2001 \\
\text { TTG PERUBAHAN ATAS UU } \\
\text { RI NO } 31 \text { THN } 1999 \text { TTG PTP } \\
\text { KORUPSI, JO PSL } 55 \text { (1) ke } 1 \mathrm{e} \\
\text { KUHP }\end{array}$ & $\begin{array}{l}\text { DESA LALA } \\
\text { TTG } \\
\text { PEMBANGUN } \\
\text { AN } 3 \quad \text { (Tiga) } \\
\text { GEDUNG } \\
\text { WORKSHOP } \\
\text { BLK (Balai } \\
\text { Latihan Kerja) }\end{array}$ & $\begin{array}{l}455 . \\
2,-\end{array}$ \\
\hline $\begin{array}{l}\text { MAS }{ }^{e e} U D \\
\text { MAMULAT } \\
Y\end{array}$ & SDA & $\begin{array}{l}\text { PSL } 2 \text { (1) JO PSL } 3 \text { JO PSL } 7 \text { (1) } \\
\text { huruf a, UU RI N0 } 31 \text { THN } \\
1999 \text { TTG KORUPSI, TELAH } \\
\text { DIUBAH DGN UU RI NO } 20 \\
\text { THN } 2001 \text { TTG PERUBAHAN } \\
\text { ATAS UU RI NO } 31 \text { THN } 1999 \\
\text { TTG PTP KORUPSI, JO PSL } 55 \\
\text { (1) KUHP }\end{array}$ & $\begin{array}{l}\text { DESA LALA } \\
\text { TTG } \\
\text { PEMBANGUN } \\
\text { AN } 3 \quad \text { (Tiga) } \\
\text { GEDUNG } \\
\text { WORKSHOP } \\
\text { BLK (Balai } \\
\text { Latihan Kerja) }\end{array}$ & $\begin{array}{l}455 . \\
2,-\end{array}$ \\
\hline $\begin{array}{l}\text { EDI } \\
\text { SURATNO, } \\
\text { ST } \\
\quad 134\end{array}$ & SDA & $\begin{array}{l}\text { PRIMER PSL } 2 \text { (1) SUB. PSL } 3 \\
\text { LEBIH SUB. PSL } 7 \text { (1) huruf b, } \\
\text { LEBIH SUB LAGI PSL 9, UU } \\
\text { RI N0 } 31 \text { THN } 1999 \text { TTG } \\
\text { KORUPSI, TELAH DIUBAH }\end{array}$ & $\begin{array}{l}\text { DESA LALA } \\
\text { TTG } \\
\text { PEMBANGUN } \\
\text { AN } 3 \quad \text { (Tiga) } \\
\text { GEDUNG }\end{array}$ & $\begin{array}{l}455 . \\
2,-\end{array}$ \\
\hline
\end{tabular}




\begin{tabular}{|l|l|l|l|l|l|}
\cline { 3 - 6 } & & & $\begin{array}{l}\text { DGN UU RI NO 20 THN 2001 } \\
\text { TTG PERUBAHAN ATAS UU } \\
\text { RI NO 31 THN 1999 TTG PTP } \\
\text { KORUPSI, JO PSL 55 (1) ke 1e } \\
\text { KUHP }\end{array}$ & $\begin{array}{l}\text { WLK } \\
\text { (Bala }\end{array}$ \\
\hline 2012 & NIHIL & NIHIL & NIHIL & NIHIL & NIH \\
\hline 2013 & NIHIL & NIHIL & NIHIL & NIHIL & NIH \\
\hline
\end{tabular}

Sumber Data : Sat Reskrim Polres Buru 2013 
Dari data penegakan tindak pidana korupsi pada tingkat kepolisian di Kabupaten Buru menunjukan adanya persentase yang tidak seimbang dengan isu publik tentang tindak pidana korupsi di Kabupaten Buru. Karena dari tahun 2006 sampai tahun 2013 hanya 2 (dua) kasus korupsi di Kabupaten Buru yang dapat diusut oleh Sat Reskrim Polres Buru sesuai tahap acara pidana samapi pada tahap siap disidangkan (P-21). Sehingga dapat dikatakan bahwa tindak pidana korupsi sebagai kejahatan luar biasa di Kabupaten Buru belum menjadi prioritas utama dalam penegakan hukum di tingkat Kepolisian di Kabupaten Buru.

\section{Penegakan Hukum Tindak Pidana Korupsi Di Tingkat}

\section{Penuntutan}

Segubungan dengan penegakan hukum pada tingkat penuntutan maka dapat dilihat pada penanganan tindak pidana korupsi pada tingkat Kejaksaan Negeri Namlea, dalam uaraian tabel. 8 sebagaimana berikut :

Tabel. 10

Penegakan Hukum Tindak Pidana Korupsi Di Kab. Buru Pada Kejaksaan Negeri Namlea Tahun 2009 s/d 2013:112

\begin{tabular}{|c|c|c|c|c|}
\hline No & $\begin{array}{l}\text { Tahun } \\
\text { Penanganan }\end{array}$ & Register & Tindak Korupsi & Ket \\
\hline 1 & 2009 & $\begin{array}{l}\text { - / terhadap } \\
\text { Ali Letetuni }\end{array}$ & $\begin{array}{lr}\text { APBD } & \text { Dinas } \\
\text { Pendidikan } & \text { Kab. } \\
\text { Buru, Pembangunan } \\
\text { SD } & \text { Impres } \\
\text { Masnana. } & \\
\text { T.A 2009 } & \\
\end{array}$ & P-21 \\
\hline 2 & 2009 & $\begin{array}{l}\text { - / terhadap } \\
\text { Hakim Fatsei } \\
\text { Usman Banda }\end{array}$ & $\begin{array}{lr}\text { APBD } & \text { Dinas } \\
\text { Pendidikan } & \text { Kab. } \\
\text { Buru T.A 2009 } & \end{array}$ & P-21 \\
\hline 3 & 2010 & $\begin{array}{l}\text { - /terhadap } \\
\text { Sinyo Kailul }\end{array}$ & $\begin{array}{l}\text { APBD Kab. Kep. } \\
\text { Buru Raskin } \\
\text { Desa Jiku } \\
\text { Marasa T.A } 2010\end{array}$ & P-21 \\
\hline 4 & 2010 & $\begin{array}{l}\text { - / terhadap } \\
\text { Majit Tualeka }\end{array}$ & $\begin{array}{lr}\text { APBD } & \text { Dinas } \\
\text { Pendidikan } & \text { Kab. }\end{array}$ & P-21 \\
\hline
\end{tabular}


112 Sumber Data: Kejaksaan RI Negeri Namlea Tahun 2014 


\begin{tabular}{|c|c|c|c|c|}
\hline & & & $\begin{array}{l}\text { Buru, SMP Danau } \\
\text { Rana T.A } 2010\end{array}$ & \\
\hline 5 & 2010 & $\begin{array}{l}\text { - / terhadap } \\
\text { Mahmud Tan }\end{array}$ & $\begin{array}{l}\text { APBD DAK Dinas } \\
\text { Pertanian Kab. Buru, } \\
\text { T.A } 2010\end{array}$ & P-21 \\
\hline 6 & 2011 & $\begin{array}{l}\text {-/terhadap } \\
\text { Z. Bamatraf }\end{array}$ & $\begin{array}{l}\text { APBD Kab. Buru, } \\
\text { Pembangunan } \\
\text { Rumah KAT Waeapo } \\
\text { T.A } 2011\end{array}$ & P-21 \\
\hline 7 & 2011 & $\begin{array}{l}\text { - / terhadap } \\
\text { Harun Awad } \\
\text { Masud } \\
\text { Mamulati } \\
\text { Edy Susetyo }\end{array}$ & $\begin{array}{lr}\text { APBD, } & \text { Dinas } \\
\text { Nakertrans } & \text { Kab. } \\
\text { Buru, Pembangunan } \\
\text { Balai Latihan } & \text { Kerja } \\
\text { lala T.A 2011 } & \end{array}$ & P-21 \\
\hline 8 & 2012 & $\begin{array}{l}\text { - / terhadap } \\
\text { Bahri Umasugi }\end{array}$ & $\begin{array}{lr}\text { APBD } & \text { Dinas } \\
\text { Perhubungan Kab. } & \text { Karu, Pembangunan } \\
\text { Buru } & \\
\text { Bandara Namlea, } & \\
\text { T.A } & \\
2012 & \end{array}$ & P-21 \\
\hline 9 & 2013 & $\begin{array}{l}\text { - / terhadap } \\
\text { Said Agil } \\
\text { Boften } \\
\text { Justi } \\
\text { Latuconsina }\end{array}$ & $\begin{array}{ll}\text { APBD } & \text { Badan } \\
\text { Pengelolaan } & \\
\text { Lingkungan } & \text { Hidup } \\
\text { Kab. Buru, T.A } 2013\end{array}$ & P-21 \\
\hline
\end{tabular}

Sumber Data: Kejaksaan Negeri Namlea, 2014

Dengan demikian dapat terlihat adanya pendokumentasian terhadap dokumen dari kejaksaan yang agak kurang transparantif sehingga penelitian ini tidak dapat menemukan adanya nomor registrasi atas indikasi tindak pidana korupsi yang ditangani di Kejaksaan Negeri Namlea.

\section{Penegakan Hukum Tindak Pidana Korupsi Di Tingkat} Pengadilan

Penegakan hukum tindak pidana korupsi pada tingkat pengadilan terhadap tindak pidana korupsi di Kabupaten Buru yang diadili pada Pengadilan Negeri 
Ambon dalam kurun waktu 2008 s/d 2014 adalah dapat dijelakan sebagai mana berikut:

Tabel. 11

Penegakan Hukum Tindak Pidana Korupsi Di Kab. Buru

Pada Pengadilan Negeri Ambon Tahun 2008 s/d 2014113

\begin{tabular}{|c|c|c|c|c|c|c|}
\hline No & Tahun & Nomor Putusan & $\begin{array}{l}\text { Tindak } \\
\text { Korupsi }\end{array}$ & Amar Putusan & $\begin{array}{l}\text { Kerugian } \\
\text { Negra }\end{array}$ & Ket \\
\hline (1) & (2) & (3) & (4) & (5) & (6) & (7) \\
\hline 1 & 2008 & $\begin{array}{l}\text { 94/Pid.B/2007 } \\
\text { /PN.AB } \\
\text { Terhadap } \\
\text { Pihak: Ir. } \\
\text { Machmud Tan }\end{array}$ & $\begin{array}{l}\text { APBD, Pada } \\
\text { Dinas } \\
\text { Pertanian } \\
\text { Tanaman } \\
\text { Pangan Kab. } \\
\text { Buru T.A. } \\
2001,2002 \& \\
2003\end{array}$ & $\begin{array}{l}\text { Menghukum: } \\
\text { Pidana } \\
\text { Penjara } 1 \\
\text { (satu) Tahun, } \\
\text { Denda } \\
\text { Rp.50.000.000., } \\
\text { - dan Uang } \\
\text { pengganti } \\
\text { sebesar } \\
\text { Rp.46.075.000,- } \\
\text { dst. }\end{array}$ & Rp.46.075.000,- & $\begin{array}{l}\text { Reg: Tgl. 25- } \\
\text { 03-2007 } \\
\text { Putus: Tgl. } \\
\text { 07-04-2008 }\end{array}$ \\
\hline 2 & 2009 & - & - & - & - & - \\
\hline 3 & 2010 & - & - & - & - & - \\
\hline 4 & 2011 & $\begin{array}{l}\text { 05/Pid.B/2011 } \\
\text { /PN.AB } \\
\text { Terhadap } \\
\text { Pihak: Bahri } \\
\text { Umasugi,SH. } \\
\text { MM }\end{array}$ & $\begin{array}{l}\text { APBD, Pada } \\
\text { Dinas } \\
\text { Perhubungan } \\
\text { \& Pariwisata } \\
\text { Kab. Buru } \\
\text { T.A. 2008 } \\
\text { (Pembanguna } \\
\text { n Bandara } \\
\text { Namniwel) }\end{array}$ & $\begin{array}{l}\text { Bebas/Lepas: } \\
\text { Menyatakan } \\
\text { Terdakwa } \\
\text { Lepas Dari } \\
\text { Segala } \\
\text { Tuntutan } \\
\text { (Onslagh van } \\
\text { allerecht), dst. }\end{array}$ & $\begin{array}{l}\text { Rp.140.497.5 } \\
00,\end{array}$ & $\begin{array}{l}\text { Reg: Tgl. 06- } \\
\text { 01-2011 } \\
\text { Putus: Tgl. } \\
\text { 26-05-2011 } \\
\text { Status: } \\
\text { Kasasi }\end{array}$ \\
\hline 5 & 2011 & $\begin{array}{l}\text { 06/Pid.B/2011 } \\
\text { /PN.AB } \\
\text { Terhadap } \\
\text { Pihak: Arifin } \\
\text { Soamole }\end{array}$ & $\begin{array}{l}\text { APBD, Pada } \\
\text { Dinas } \\
\text { Perhubungan } \\
\text { \& Pariwisata } \\
\text { Kab. Buru } \\
\text { T.A. } 2008 \\
\text { (Pembanguna } \\
\text { n Bandara } \\
\text { Namniwel) }\end{array}$ & $\begin{array}{l}\text { Bebas/Lepas: } \\
\text { Menyatakan } \\
\text { Terdakwa } \\
\text { Lepas Dari } \\
\text { Segala } \\
\text { Tuntutan } \\
\text { (Onslagh van } \\
\text { allerecht), dst. }\end{array}$ & $\begin{array}{l}\text { Rp.140.497.5 } \\
00,\end{array}$ & $\begin{array}{l}\text { Reg: Tgl. 02- } \\
\text { 02-2011 } \\
\text { Putus: Tgl. } \\
\text { 05-07-2011 } \\
\text { Status: } \\
\text { Kasasi }\end{array}$ \\
\hline 6 & 2012 & $\begin{array}{l}\text { 11/Pid.Sus/20 } \\
\text { 12/PN.AB }\end{array}$ & $\begin{array}{l}\text { APBD, Pada } \\
\text { Dinas Tenaga }\end{array}$ & $\begin{array}{l}\text { Menghukum: } \\
\text { Pidana }\end{array}$ & $\begin{array}{l}\text { Rp.455.694.3 } \\
85.22,-\end{array}$ & $\begin{array}{l}\text { Reg: Tgl. 25- } \\
\text { 04-2012 }\end{array}$ \\
\hline
\end{tabular}

113 Sumber: Web. Resmi Putusan Piana Kusus-Korupsi Mahkamah Agung RI: mahkamahagung.go.id, 2014. Laman PN. Ambon. 


\begin{tabular}{|c|c|c|c|c|c|c|}
\hline & & $\begin{array}{l}\text { Terhadap } \\
\text { Pihak: Ir. } \\
\text { Harun Awad }\end{array}$ & $\begin{array}{l}\text { Kerja } \\
\text { \&Transmigras } \\
\text { i Kab. Buru. } \\
\text { T.A. } 2009\end{array}$ & $\begin{array}{l}\text { Penjara } 2 \\
\text { Tahun } 6 \\
\text { Bulan, denda } \\
\text { Rp.50.000.000,- } \\
\text { dan } \\
\text { membayar } \\
\text { ganti rugi } \\
\text { sebesar } \\
\text { Rp.455.694.385 } \\
.32,- \text { dst. }\end{array}$ & & $\begin{array}{l}\text { Putus: Tgl. } \\
14-08-2012\end{array}$ \\
\hline 7 & 2012 & $\begin{array}{l}\text { 01/Pid.Sus/20 } \\
\text { 11/PN.AB } \\
\text { Terhadap } \\
\text { Pihak: La Une } \\
\text { Buton }\end{array}$ & $\begin{array}{l}\text { Pada Raskin } \\
\text { Desa } \\
\text { Wailihang } \\
\text { Kec. Waplau. } \\
\text { T.A. } 2008 \text { dan } \\
2009\end{array}$ & $\begin{array}{l}\text { Menghukum: } \\
\text { Pidana } \\
\text { Penjara } \\
\text { tahun, } \\
\text { membayar } \\
\text { uang } \\
\text { pengganti } \\
\text { sebesar } \\
\text { Rp.33.530.000,- } \\
\text { dst. }\end{array}$ & $\begin{array}{l}\text { Tahun 2008: } \\
\text { Rp.9.190.00,- } \\
\text { Tahun 2009: } \\
\text { Rp.33.980.00 } \\
\text { Total: } \\
\text { Rp.43.170.00 } \\
\text {,- }\end{array}$ & $\begin{array}{l}\text { Reg: Tgl. 22- } \\
\text { 02-2011 } \\
\text { Putus: Tgl. } \\
\text { 27-02-2012 }\end{array}$ \\
\hline 8 & 2013 & $\begin{array}{l}\text { 05/Pid.Tipiko } \\
\text { r/2013/PN.A } \\
\text { B } \\
\text { Terhadap } \\
\text { Pihak: Said } \\
\text { Agil Boften }\end{array}$ & $\begin{array}{l}\text { DAK APBD, } \\
\text { Pada Kantor } \\
\text { Lingkungan } \\
\text { Hidup Kab. } \\
\text { Buru T.A. } 2010\end{array}$ & $\begin{array}{l}\text { Menghukum: } \\
\text { Pidana } \\
\text { Penjara } \\
\text { Tahun, denda } \\
\text { Rp.50.000.000,- } \\
\text { dan } \\
\text { membayar } \\
\text { uang penggati } \\
\text { sebesar } \\
\text { Rp.619.239.950 } \\
.91,- \text { dst. }\end{array}$ & $\begin{array}{l}\text { Rp.619.239.9 } \\
50.91,-\end{array}$ & $\begin{array}{l}\text { Reg: Tgl. 06- } \\
\text { 03-2013 } \\
\text { Putus: Tgl. } \\
\text { 24-09-2013 }\end{array}$ \\
\hline 9 & 2014 & $\begin{array}{l}\text { 16/Pid.Tipiko } \\
\text { r/2013/PN.A } \\
\text { B } \\
\text { Terhadap } \\
\text { Pihak: Ir. Jusdi } \\
\text { Rahman } \\
\text { Latuconsina }\end{array}$ & $\begin{array}{l}\text { DAK APBD, } \\
\text { Pada Kantor } \\
\text { Lingkungan } \\
\text { Hidup Kab. } \\
\text { Buru T.A. } 2010\end{array}$ & $\begin{array}{l}\text { Menghukum: } \\
\text { Pidana } \\
\text { Penjara } 2 \\
\text { Tahun, denda } \\
\text { Rp.50.000.000,- } \\
\text { dst. }\end{array}$ & $\begin{array}{l}\text { Rp.619.239.9 } \\
50.91,-\end{array}$ & $\begin{array}{l}\text { Reg: Tgl. 13- } \\
\text { 11-2013 } \\
\text { Putus: Tgl. } \\
\text { 21-05-2014 }\end{array}$ \\
\hline
\end{tabular}

Sumber Data : Pengadilan Negeri Ambon 2014

Dari tabel. 10 menunjukan bahwa penanganan tindak pidana korupsi pada tingkat pengadilan bagi pelaku tindak pidana korupsi dalam penyelenggaraan pemerintahan di Kabupaten Buru sejak tahun 2008 s/d tahun 2014 hanya 
berjumlah 9 (sembilan) kasus dengan rincian bahwa 7 (tujuh) kasus diputus bersalah (menghukum), sedangkan 2 (dua) kasus diputus lepas dari tuntutan (bebas).

\section{Penegakan Hukum Oleh Lembaga Pelaksana Putusan} Pengadilan / Lembaga eksekutor / Pemasyarakatan

Terhadap semua putusan Pengadilan Negeri Ambon dalam menghukum pelaku tindak pidana korpsi di Kabupaten Buru telah menjalni hukuman sebagai mana putusan pengadilan serta peraturan dalam ketentuan eksekutorial pada Lembaga Pemasyarakatan Kelas II Ambon.

\section{Analisis Penegakan Hukum Tindak Pidana Korupsi}

\section{Menunjukan Nilai Positif}

Bahwa secara keseluruhan dari uraian di atas menunjukan bahwa penyelenggaraan pemerinthana di Kabupaten Buru dalam Tindak pidana korupsi berdasarkan putusan pengadilan Negeri Ambon menunjukan bahwa penyelenggaraan pemerintahan di Kabupaten Buru masih rendah tingkat tindak pidana korupsinya.

\section{Menunjukan Nilai Negatif}

Bahwa dengan berbagai uraian di atas secara komprehensif analitik dapat ditemukan beberapa kelemahan-kelemahan mendasar yang menunjukkan lemahnya akuntablitas pengelolaan APBD dalam penyelenggaraan pemerinthan di Kabupaten Buru dan tidak maksimalnya lembaga penegak hukum ditingkat kepolisian dan kejaksaan guna pengungkapan tindak pidana korupsi dalam penyelenggaraan pemerintahan di Kabupaten Buru, hal ini dapat terlihat dalam analisis penulis sebagai berikut:

a. Kulaitas Aparaur Daerah Kabupaten Buru yang belum mumpuni dan terbatasnya Sumberdaya aparatur yang memiliki kemampuan manajemen pengelolaan akuntabilitas APBD yang terdistribusi di setiap SKPD di linkup pemerintahan Kabupaten Buru. 
b. Dalam pengelolaan APBD dari tahun anggaran 2008, 2009 dan 2012 menujukan angka devisit sehingga secara formal menggambarkan adanya kelemahan akuntabilitas pengelolaan APBD di Kabupaten Buru.

c. Sejalan dengan pengelolaan APBD di atas berdasar pada Opini Hasil Pemeriksaan BPK-RI Perwakilan Provinsi Maluku terhadap Laporan Keuangan Pemerintah Daerah Kabupaten Buru untuk tahun 2008-2012 adalah

disclaimer. Olehnya itu secara formal menujukan adanya kelemahan secara mendasar dalam akuntabiltas pengelolaan APBD di dalam penyelenggaraan pemerinthan di Kabupaten Buru.

d. Secara formal berdasarkan data yang ditemukan dari lembaga penegakan hukum menujukan adanya kelemahan dalam penegakan hukum diantaranya:

1) Kurang maksimalnya lembaga Kepolisian Rseort Kab. Buru dan lembaga Kejaksaan Negeri namlea dalam mengusut ketimpangan akuntabilitas pengelolaan APBD dalam penyelengaraan pemerintahan di Kabupaten Buru yang dari tahun 2008 s/d 2009 hanya berhasil mengusut sampai pada putusan pengadilan mengungkap 9 (sembilan) pelaku kasus kiorupsi yang 2 (dua) diantaranya diputus bebas.

2) Adanya kelemahan administrasi dalam pendataan penanganan kasus tindak pidana korupsi di tingkat Kejaksaan Negeri Namlea ini tercermin dalam data tindak pidana korupsi penyimpangan APBD kabupaten buru yang tidak selaras dengan data pada putusan pengadilan Negeri Ambon.

3) Lambannya penanganan bagi pelaku kasus tindak pidana korupsi pada pengelolaan APBD dalam penyelenggaraan pemerinthan di Kabupaten Buru sampai pada proses pengadilan. Ini tergambar pada tabel. 11 dimana selisih waktu/tahun register putusan pengadilan dengan waktu/tahun penyimpangan pengelolaan APBD dalam penyelenggaraan 
pemerintahan di Kabupaten Buru selisi tahun penenagnannya sangat terlampau jauh. 


\section{BAB VIII \\ PENUTUP}

Dalam uraian yang telah dikemukakan penulis berdasarkan pada permasalahan yang diteliti dan ditelusuri dengan menggunakan metode penelitian hukum secara sistematis, sebagai bentuk kajian hukum dalam uraian-uarian yang telah dikemukakan, maka dapat disimpulkan beberapa hal dalam Penegakan Hukum Terhadap Pelaku Tindak Pidana Korupsi Di Kabupaten Buru yaitu faktor-faktor penyebab terjadinya tindak pidana korupsi di Kabupaten Buru adalah dapat terkaji dari beberapa aspek secara substansial yaitu; bahwa faktor pendorong utama terjadinya tindak pidana korupsi adalah faktor manusia (individu) sebagai pelaku dalam sistem pengambilan kebijakan Anggaran pada pengelolaan APBD dalam penyelenggaraan pemerintahan di Kabupaten Buru, faktor manusia (inidividu) ini terakumulasi dalam pengaruh baik secara internal maupun eksternal. Faktor individu secara internal ini bertumpu pada kualitas moral dari pada individu tersebut dimana semua pelaku tindak pidana korupsi memiliki kualitas moral yang lemah. Sedangkan faktor individu secara eksternal ini bertumpu pada himpitan kebutuhan ekonomi, serta peluang yang memungkinkan dalam lemahnya Sistem Pengendalian, pengawasan Manajemen dan Tata Kelola Pemerintahan di Daerah, sehingga memungkinkan individu dalam melakukan tindak pidana korupsi di Kabupaten Buru.

Selain itu terdapat foktor kondisional dan indikator objektif sebagai faktor formal dalam memperkuat kemungkinankemungkinan tejadinya tindak pidana korupsi dalam penyelengaraan pemerinthan di Kabupaten Buru, yaitu; faktor kondisional: kualitas sumber daya aparatur di Kabupaten Buru sebagai kabupaten kepulauan dirasa masih terbatas serta belum mumpuni dalam penguasaan manajemen akuntabilitas pengelolaan ABPD dalam penyelenggaraan pemerintahan di 
Kabupaten Buru. Indikator objektif: indikator dalam pengelolaan anggaran pendapatan belanja daerah di Kabupaten Buru yang dalam 5 (lima) tahun terakhir $(2008,2009,2012)$ menunjukan angka DEVISIT, serta Indikator dalam Opini Hasil Pemeriksaan BPK-RI Wilayah Provinsi Maluku atas laporan keuangan pemerintah daerah Kabupaten Buru yang dinyatakan bahwa pengelolaan APBD kabupaten buru 5 (lima) tahun terakhir (2008 s/d 2012) mendapat predikat DISCLAIMER (BPK tidak berpendapat atas laporan keuangan pemerintah daerah Kab. Buru) oleh BPK-RI Wilayah Maluku.

Penegakan hukum terhadap pelaku tindak pidana korupsi di Kabupaten Buru oleh lembaga penegak hukum dalam sistem peradilan pidana dirasa masih belum berjalan secara maksimal terlihat dalam kurun waktu 7 (tujuh) tahun hanya berhasil menangani pelaku tindak pidana korupsi sampai pada putusan pengadilan negeri Ambon adalah sebanyak 9 (sembilan) pelaku kasus korupsi dimana 7 (tujuh) pelaku kasus korupsi divonis bersalah sedangkan 2 (dua) pelaku kasus Korupsi divonis Bebas. Selain itu penegakan hukum bagi pelaku tindak pidana korupsi di kabupaten buru, proses pengakan hukumnya dirasa sangatlah lambat sehingga mengindikasikan bahwa sistem peradilan pidana dalam tindak pidana korupsi di Kabupaten Buru belum berjalan sebagaimana yang diharapkan. 


\section{DAFTAR PUSTAKA}

\section{SUMBER BUKU :}

Abdulsyani. 1987, Sosiologi Kriminologi. Ramaja Karya, Bandung.

Achmad Zainuri, 2007, Akar Kultural Korupsi di Indonesia, Cahaya BaruSawangan, Depok

Agus Salim Andi Gadjong, 2007, Pemerintah Daerah Kajian

Politik dan Hukum, Ananta. Jakarta.

Andi Hamzah, 1983. Hukum Pidana Ekonomi. Erlangga Jakarta.

1991, Korupsi di Indonesia, Masalah dan

Pemecahannya, PT. Gramedia Pustaka Utama, Jakarta. ,2005, Pemberantasan Korupsi, Jakarta : PT.

Raja Grafindo persada.

Atmosudirdjo Prajudi, 1994, Teori Administrasi, STIALAN, Jakarta, .

Azhari Tahir, Negara Hukum, 1992, Bulan Bintang, Jakarta.

Baharuddin Lopa. 2001. Kejahatan Korupsi dan Penegakan Hukum. Buku Kompas. Jakarta.

Barda Nawawi Arief, 2001, Masalah Penegakan Hukum dan Kebijakan Penanggulangan Kejahatan, Citra Adtya Bakti, Bandung. -,2007. Masalah Penegakan Hukum dan

Kebijakan Hukum Pidana dalam Penanggulangan Kejahatan.

Jakarta : Kencana Prenada Media Group.

$$
\text { , 2, 2007, Masalah Penegakan Hukum Dan }
$$

Kebijakan Hukum Pidana, Dalam Penanggutangan Kejahatan, Jakarta, Kencana Praneda Media.

2010, Masalah Penegakan Hukum dan

Kebijakan Hukum Pidana dalam Penanggulangan Kejahatan, Kencana Prenada Media Group. Jakarta.

,2011, Bunga Rampai Kebijakan Hukum

Pidana, Jakarta: Prenada Media Group.

Chairul Huda, 2006, Dari Tiada Pidana Tanpa Kesalahan Menuju Kepada Tiada Pertanggungjawaban Pidana Tanpa Kesalahan,

Kencana Prenada Media, Jakarta. 
C.S.T. Kansil, SH dan Christine S.T. Kansil, SH, M.H, 1997, Hukum Tata Negara Republik Indonesia 1, Penerbit Rineka Cipta, Jakarta.

Djoko Prakoso dan Ati Suryati, 1986, Upetisme Ditinjau Dari Undang-undang Pemberantasan Tindak Pidana Korupsi,

Bumi Aksara, Jakarta

Daryanto, 1997, Kamus Lengkap Bahasa Indonesia, Apollo, Surabaya.

Friedman, M. 2001. Lawrence, American Law An

Introduction, Second Edition (Hukum Amerika Sebuah Pengantar, Penerjemah Wishnu Basuki, Penerbit PT. Tatanusa, Jakarta, e-USU Repository (C2004 Universitas Sumatera Utara.

Johnny Ibrahim, 2005, Teori dan Metodelogi Penelitian

Hukum Normatif, Bayumedia, Malang.

Kumorotomo, Wahyudi. 2005. Etika Administrasi Negara, Rajawali Pers: Jakarta

La Patra, 1978, Analizing the Criminal Justice System,

Lexington Books, Toronto.

Mardjono Reksodiputro, 1993, Sistem Peradilan Pidana di Indonesia, Pidato Pengukuhan Guru Besar tetap dalam Ilmu Hukum pada Fakultas Hukum Universitas Indonesia.

Martiman Prodjohamidjojo, 2001, Penerapan Pembuktian Terbalik dalam Delik Korupsi (UU No. 20 Tahun 2001), CV. Mandar Maju, Jakrta.

Mochtar Lubis dan James C. Scott, Bunga Rampai Korupsi, Cet. ke-3 (Jakarta: LP3ES, 1995).

Muhammad Tahir Azhari, 1995, Negara Hukum Indonesia, UI-Press, Jakarta.

Muladi, 1995, Kapita Selecta System Peradilan Pidana,

Penerbit Universitas Diponegoro. Semarang. -,2010, Teori-teori dan Kebijakan Pidana, Jakarta.

Padmo Wahyono, 1982, Negara Republik Indonesia, CV. Rajawali, Jakarta.

Peter Mahmud Marzuki, 2011, Penelitian Hukum, Faiar Interpratama offset, Jakarta Cetakan Ke-7. 
Purbacaraka, Purnadi dan Soerjono Soekanto, 1979, Perihal Kaedah Hukum, Alumni, Bandung.

Rachbini, Didik J. 2004, Ekonomi Politik, Kebijakan dan Strategi Pembangunan, Granit, Jakarta.

Ridwan HR. 2007, Hukum Administrasi Negara, Raja Grafindo. Jakarta.

Riduan Syahrani, 1983, Beberapa hal Tentang Hukum Acara Pidana, Alumni, Bandung.

Romli Atmasasmita, 1983, Bunga Rampaian Kriminologi. Rajawali, Jakarta. ,2010, Sistem Peradilan Pidana Kontemporer,

Kencana Prenada Media Grup, Jakarta.

Ruslan Saleh, 1988, Perbuatan Pidana dan Pertanggungjawaban Pidana Dan Pengertian Dasar dalam Hukum Pidana, Citra Aditya Bakti, Bandung.

Satjipto Rahardjo, 2010, Penegakan Hukum Progresif,

Penernit Buku Kompas, Jakarta.

Soerjono Soekanto, 1983, Beberapa Aspek Sosio Yurudis Masyarakat, Alumni, Bandung.

Soedjono Dordjosisworo, 1986, Fungsi Perundang-undangan Pidana Dalam Penanggulangan Korupsi di Indonesia, Sinar Baru, Bandung.

Sudarto, 1981, Suatu Dilema Dalam Pembaharuan Sistem Pidana Indonesia, Pidato Pengukuhan Guru Besar Tetap Dalam Mata Pelajaran Hukum Pidana Pada Universitas Diponegoro, Semarang 21 Desember 1974. Dalam Beberapa Guru Besar Berbicara Tentang Hukum (Kumpulan Pidato-Pidato Pengukuhan), Bandung Alumni. 1986. Hukum dan Hukum Pidana, Bandung, Alumni, 1990, Hukum Pidana I, Semarang : Yayasan

Sudarto.

Trisno Raharjo, 2011, Mediasi Pidana Dalam Sistem Peradilan Pidana: Suatu Kajian Perbandingan dan Penerapannya di Indonesia, Buku Litera: Jogjakarta. 


\section{SUMBER KARYA ILMIYAH :}

A.Azis Maulana, 2013, Criminal Justice System Sistem Peradilan Pidana, Materi Kuliah Pada STIH sunan Giri, Malang.

Ahmad Latupono, 2012, Tesis, Efektifitas Penanganan Perkara Tindak Pidana Korupsi Pada Pengadilan Tindak Pidana Korupsi Di Wilayah Kepulauan, Unpatti, Ambon.

Barda Nawawi Arief, 1991, Upaya Non dalam Kebijakan Penanggulan Kejahatan, Bahan Seminar Kriminologi. UNDIP. Semarang.

-----------------,2003, Sistem Peradilan Pidana Terpadu

dalam Kaitannya dengan Pembaruan Kejaksaan, dalam Media Hukum Vol. 2 Nomor 1, Tahun 2003.

Fathur Rohman, 2009, Matakuliah Anti-Korupsi, FaktorFaktor Penyebab Korupsi, Universitas Paramadina, Jakarta.

Ichwan B. A, 2010, Perumusan Delik (Perbuatan) Korupsi, Artikel, 11, August

hal.

http://wanspeak.wordpress.com/2010/08/11/319/.

Iskatrinah, (2007), Pelaksanaan Fungsi Hukum Administrasi Negara. http://buletinlitbang.dephan.go.id.

Mochtar Kusumaatmadja, 1995, Pemantapan Cita Hukum dan Asas Hukum Nasional di Masa Kini dan Masa Yang Akan Datang, Makalah, Jakarta.

Romli Atmasasmita, 1998, Prospek Penangilangan Korupsi Di Indonesia Memasuki Abad ke XXI : Suatu Reoreinlasi atas Kebijakan Hukum Pidana di Indonesia, Pidato Pengukuhan

Jabatan Guru Besar Madya dalam Ilmu Hukum pada Fakultas Hukum Universitas Padjajaran, Bandung, 25 September, 1998.

Tjandara Sridjaja Pradjonggo, 2007, Sifat Melawan Hukum Dalam Tindak Pidana Marwan Efendy, Pengadilan Tindak Pidana Korupsi, Lokakarya Anti-Korupsi Bagi Jurnalis, Surabaya.

\section{SUMBER DATA INSTANSI DAN MEDIA :}

Badan Pusat Statistik Kabupaten Buru (BPS), Buru Dalam Angka Tahun, 20013.

Inspektorat Kab. Buru 2013

Kejaksaan RI Negeri Namlea Tahun 2014

Satreskrim Polres Pulau Buru, 2014 
Pengadilan Negeri Ambon, 2014, Web. Resmi Putusan Piana Kusus-Korupsi Mahkamah Agung RI: mahkamahagung.go.id, 2014. Laman PN. Ambon.

Data FITRA, 2013,

http://indonesiatimurvoice.blogdetik.com /2013/08/13/versifitra

Indonesia Lawyer Club, Korupsi, Surabaya, 2010.

Sumber Berita: MailArchive.com 16 Desember 2008.

Sumber Berita: Siwalimanews, Selasa, 28 Desember 2010

Sumber Berita: Siwalimanews, Kamis, 16 Desember 2010

Sumber Berita: Siwalimanews, Selasa, 7 September 2010

Sumber Berita: Siwalimanews, Rabu, 9 Juni 2010 Sumber

Berita: Siwalimanews, 27 Mei 2010

Sumber Berita: Siwalimanews, 11 Mei 2010.

Sumber Berita: Siwalimanews, Selasa, 8 Maret 2011

http://www.transparency.org, diakses, 29 Oktober 2012.

http://nusantaranews.wordpress.com/2010/03/09/prestas i-terus-naik-indonesia-negara-terkorup-asia-2010/. Okezone, 11 Maret 2008. Diakses 29 Oktober 2013.

http://www.tribunnews.com/nasional/2012/10/01/inidia-peringkat-provinsi-terkorup-di-indonesia. Diakses 29 Oktober 2013.

\section{SUMBER PERATURAN PERUNDANG-UNDANGAN:}

Undang-Undang No. 31 Tahun 1999 junto UndangUndang No. 20 Tahun 2001 tentang Pemberantasan Tindak Pidana Korupsi;

Undang-Undang Nomor 8 Tahun 1981
Kitab Undang-Undang, Hukum Acara Pidana (KUHAP);

$$
\text { - Undang-Undang Nomor } 46 \text { Tahun } 2010 \text { Tentang }
$$
Pengadilan Tindak Pidana Korupsi;

- Undang-Undang No. 31 Tahun 1999 tentang Komisi Pemberantasan Korupsi (KPK) Sebagai mana diubah dengan Undang-Undang No. 30 Tahun 2002 Tentang Komisi Pemberantasan Korupsi (KPK); 